\title{
DNFSB Recommendation 94-1 Hanford Site Integrated Stabilization Management Plan
}

Date Published

September 1996

Prepared for the U.S. Department of Energy

Assistant Secretary for Environmental Management

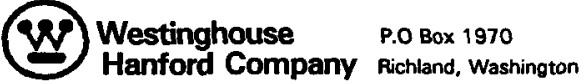

Hanford Operations and Engineering Contractor for the

U.S. Department of Energy under Contract DE-AC06-87RL10930

Approved for public release; distribution is limited 


\section{RELEASE AUTHORIZATION}

Document Number: WHC-EP-0853, Rev. 3

Document Title: $\quad$ DNFSB Recommendation 94-1 Hanford Site Integrated Stabilization Management Plan

Release Date: $\quad 9 / 23 / 96$

This document was reviewed following the procedures described in WHC-CM-3-4 and is:

APPROVED FOR PUBLIC RELEASE

WHC Information Release Administration Specialist:

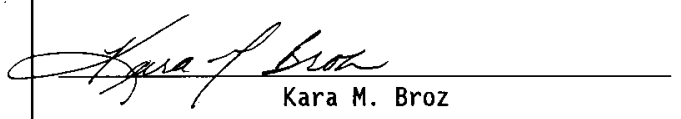

September 23, 1996 


\section{DNFSB RECOMMENDATION 94-1 \\ HANFORD SITE INTEGRATED STABILIZATION \\ MANAGEMENT PLAN}

\section{EXECUTIVE SUMMARY}

The U.S. Department of Energy (DOE) has developed an Integrated Program Plan (IPP) to address concerns identified in Defense Nuclear Facilities Safety Board (DNFSB) Recommendation 94-1. The IPP describes the actions that DOE plans to implement at its various sites to convert excess fissile materials to forms or conditions suitable for safe interim storage. The baseline IPP was issued as DOE's DNFSB Recommendation 94-1 Implementation Plan (IP), which was transmitted to the DNFSB on February 28, 1995. The IPP was subsequently supplemented with an Integrated Facilitjes Plan and a Research and Development Plan, which further develop complex-wide research and development and longrange facility requirements and plans. These additions to the baseline IPP were developed based on a systems engineering approach that integrated facilities and capabilities at the various DOE sites and focused on attaining safe interim storage with minimum safety risks and environmental impacts.

ach affected DOE site has developed a Site Integrated Stabilization Management $\mathrm{Pl}$ an (SISMP) to identify individual site plans to implement the DNFSB Recommendation 94-1 IPP. The SISMPs were developed based on the objectives, requirements, and commitments identified in the DNFSB Recommendation 94-1 IP. The SISMPs supported formulation of the initial versions of the Integrated Facilities PI an and the Research and Development PIan. The SISMPS are periodically updated to reflect improved integration between DOE sites as identified during the IPP systems engineering evaluations.

This document constitutes the Hanford SISMP. This document includes the planned work scope, costs and schedules for activities at the Hanford Site to implement the DNFSB Recommendation 94-1 IPP.

Materials within the scope of this SISMP include spent nuclear fuel (SNF) and plutonium-bearing materials currently located at the Hanford Site. The Hanford SISMP is comprised of three volumes. Volume l identifies the plans for placing these materials in safe interim storage, and Volume 2 provides integrated schedules for completing the planned work scope identified in Volume 1. Volume 3 provides more detailed plans to address resolution of plutonium vulnerabilities.

The plans identified in the Hanford SISMP will result in removal of SNF from the 105-K Basins (K Basins) by December 1999, consistent with the DNFSB's recommendation "that the program be accelerated to place the deteriorating reactor fuel in the K-East Basin at the Hanford Site in a stable configuration for interim storage until an option for ultimate disposition is chosen." The plans will also result in removal of all sludge from the $K$ Basins by December 2000. Additionally, the plans will place Hanford Site plutonium-bearing materials in safe interim storage by May 2002. 
The remaining cost to achieve safe interim dry storage of the $K$ Basins SNF is estimated at $\$ 321$ million. This cost is based on current budget estimates and includes the costs to retrieve, package, cold vacuum dry, transport, stage, condition and implement dry interim storage (i.e., characterize SNF, acquire facilities, etc.) and disposition $K$ Basins sludge. The projected cost to manage the K Basins SNF until hot conditioning is completed is $\$ 497$ million. This cost includes operations at the $K$ Basins in addition to the costs to achieve safe interim dry storage. The $\$ 497$ million estimated cost does not include the program costs associated with $K$ Basins deactivation. These costs are based on remaining costs for the activities from the beginning of fiscal year (FY) 1997 until completion.

The remaining cost to achieve safe interim storage of the plutonium-bearing materials is estimated at $\$ 124$ million. This plan assumes that DOE will reallocate resources to provide the budgets necessary to attain safe interim storage within schedule commitments. 
TABLE OF CONTENTS

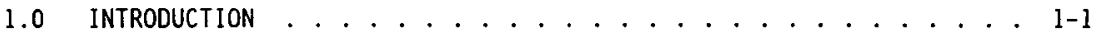

1.1 BACKGROUND ................... . . . . . .

1.2 PURPOSE ................... . . . . . .

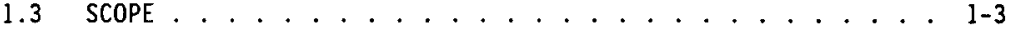

1.4 ORGANIZATIONAL RESPONSIBILITIES ........... . . 1-3

1.5 SUMMARY .......................... 1 . .

2.0 HANFORD SITE SPENT NUCLEAR FUEL ............. 2-1

2.1 K BASINS SPENT NUCLEAR FUEL .............. 2-1

2.1.1 Scope ................ 2-1

2.1.2 Remediation Objective ............ 2- 2-4

2.1.3 Remediation Process . . . . . . . . . . 2-4

2.1.4 Schedule 0bjectives . . . . . . . . . . . . 2-13

2.1.5 Assumptions ................. 2-15

2.1.6 Issues and Problems ............... 2-15

2.1.7 Alternatives . . . . . . . . . . . . . 2-16

2.1.8 Technology Development . . . . . . . . . 2-18

2.2 OTHER HANFORD SITE SPENT NUCLEAR FUEL . . . . . . . . . 2-19

2.2.1 Scope . . . . . . . . . . . . . . . 2-19

2.2.2 Remediation Objective ............. . 2-20

2.2.3 Remediation Process ........... 2-20

2.2.4 Schedule objectives . . . . . . . . . . . . 2-24

2.2 .5 Assumptions . . . . . . . . . . . . . . . . 2-25

2.2 .6 Issues and Problems ........... 2-25

2.2 .7 Alternatives . . . . . . . . . . . . 2-25

2.2.8 Technology Development . . . . . . . . . 2-26

2.3 RESOURCES ................... . . 2-26

2.4 WORK PLAN . . . . . . . . . . . . . . . . . . 2-27

2.5 STAKEHOLDER INVOLVEMENT . . . . . . . . . $2-27$

3.0 PLUTONIUM-BEARING MATERIALS . . . . . . . . . . . 3-1

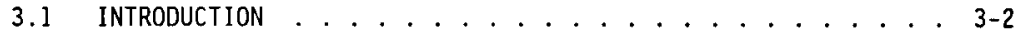

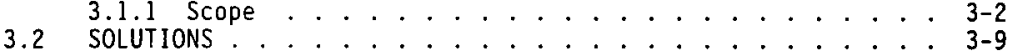

3.2 .1 Scope .......... . . . . . 3-9

3.2.2 Remediation Objectives and Endstate . . . . . 3-9

3.2.3 Remediation Process . . . . . . . . . . . . . 3-9

3.2.4 Schedule objectives ............ . 3-11

3.2.5 Assumptions ............ . . . . . . . . . . .

3.2.6 Issues and Problems . . . . . . . . . . . . 3-12

3.2 .7 Alternatives/Impacts . . . . . . . . . 3-13

3.2 .8 Technology Development . . . . . . . . 3-13

3.3 RESIDUES AND OXIDES ................ . . . . . . . . .

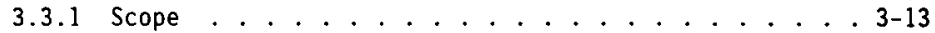

3.3.2 Remediation Objectives . . . . . . . . . . . 3-15

3.3.3 Remediation Processes ........... . . 3-17

3.3.4 Schedule 0bjectives ............ 3-20

3.3 .5 Assumptions ................ 3-20

3.3 .6 Issues and Problems ................... 3-21

3.3.7 Alternatives/Impacts . . . . . . . . . 3-21 
3.3.8 Technology Development .............. . . . . . 22

3.4 METALS AND OXIDES .................... . . . . . . . . . . . . .

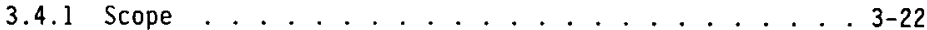

3.4 .2 Remediation Objectives ............. 3-22

3.4.3 Remediation Processes . . . . . . . . . . . . 3-23

3.4 .4 Schedule objectives . . . . . . . . . . . 3-27

3.4 .5 Assumptions . . . . . . . . . . . . 3-27

3.4 .6 Issues and Problems . . . . . . . . . . . . 3-28

3.4.7 Alternatives/Impacts . . . . . . . . . . . . . . . 3-29

3.4.8 Technology Development ............. . . 3-29

3.5 SUPPORT SYSTEMS . . . . . . . . . . . . . . . . 3-29

3.5.1 Scope ...................... 3-29

3.5 .2 Support objectives .............. . . . 3-30

3.5.3 Support Systems Descriptions . . . . . . . . 3-30

3.5.4 Schedule objectives . . . . . . . . . . . 3-30

3.5 .5 Assumptions . . . . . . . . . . . . . 3-31

3.5.6 Issues and Problems . . . . . . . . . . . . . . 3-31

3.5 .7 Alternatives/Impacts . . . . . . . . . . . . 3-31

3.5.8 Technology Development . . . . . . . . . . . 3-31

3.6 DOSE EVALUATION . . . . . . . . . . . . . . . . . . .

3.7 CHARACTERIZATION OF PLUTONIUM-BEARING MATERIALS $\ldots 3-32$

3.8 PLUTONIUM FINISHING PLANT FINAL SAFETY ANALYSIS REPORT

REVISION . . . . . . . . . . . . . . . . . .

3.9 INTERNATIONAL ATOMIC ENERGY AGENCY INTERACTION $\ldots \ldots 3-33$

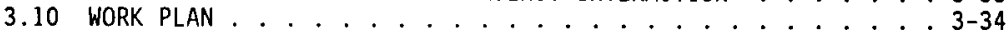

4.0 REFERENCES ...................... . . . . .

APPENDIX A: FACILITY DESCRIPTIONS .............. A-3

\section{LIST OF FIGURES}

Figure 1-1. Summary Schedule. . . . . . . . . . . . . 1-5

Figure 2-1. Location of Hanford Spent Nuclear Fuels. . . . . . . . 2-2

Figure 2-2. Fuel Removal Process. .............. 2-5

Figure 2-3. Hanford Site Spent Nuclear Fuel Flow Diagram. . . . . . . 2-22

Figure 3-1. Material Flow for DNFSB 94-1 Baseline Plan ...... 3-5

Figure 3-2. PFP Building Layout - Location of Process Areas . . . . 3-6

\section{LIST OF TABLES}

Table 1-1. Budget Profile ............. . . . . . . .

Table 2-1. Hanford Spent Nuclear Fuel Inventories. . . . . . . . . 2-3

Table 2-2. Funding Requirements ............. 2-28

Table 3-1. Inventory of Plutonium-Bearing Materials . . . . . . 3-4

Table 3-2. Milestone Summary . . . . . . . . . . . . . . . 3-7

Table 3-3. Funding Requirements ........... . 3-35 


\section{LIST OF TERMS}

\begin{tabular}{|c|c|}
\hline 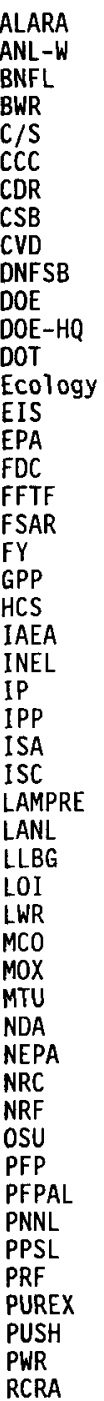 & $\begin{array}{l}\text { As Low As Reasonably Achievable } \\
\text { Argonne National Laboratory-West } \\
\text { British Nuclear Fuels, Limited } \\
\text { Boiling Water Reactor } \\
\text { Containment and Surveillance } \\
\text { Core Component Container } \\
\text { Conceptual Design Requirements } \\
\text { Canister Storage Building } \\
\text { Cold Vacuum Drying } \\
\text { Defense Nuclear Faci]ities Safety Board } \\
\text { U.S. Department of Energy } \\
\text { U.S. Department of Energy, Headquarters } \\
\text { Department of Transportation } \\
\text { Washington State Department of Ecology } \\
\text { Environmental Impact Statement } \\
\text { U.S. Environmental Protection Agency } \\
\text { Functional Design Criteria } \\
\text { Fast Flux Test Facility } \\
\text { Final Safety Analysis Report } \\
\text { Fiscal Year } \\
\text { General Plant Project } \\
\text { Hot Conditioning System } \\
\text { International Atomic Energy Agency } \\
\text { Idaho National Engineering Laboratory } \\
\text { Implementation Plan } \\
\text { Integrated Program Plan } \\
\text { Interim Storage Area } \\
\text { Interim Storage Cask } \\
\text { Los Alamos Molten Plutonium Reactor Experiment } \\
\text { Los Alamos National Laboratory } \\
\text { Low-Level Burial Ground } \\
\text { Loss On Ignition } \\
\text { Light Water Reactor } \\
\text { Multi Canister Overpack } \\
\text { Mixed Oxides } \\
\text { Metric Tons Uranium } \\
\text { Non Destructive Analysis } \\
\text { National Environmental Policy Act } \\
\text { Nuclear Regulatory Commission } \\
\text { Neutron Radiography Facility } \\
\text { Oregon State University } \\
\text { Plutonium Finishing Plant } \\
\text { Plutonium Finishing Plant Analytical } \\
\text { Pacific Northwest National Laboratory } \\
\text { Plutonium Process Support Laboratory } \\
\text { Plutonium Reclamation Facility } \\
\text { Plutonium-Uranium Extraction } \\
\text { Plutonium Stabilization and Handling } \\
\text { Pressurized Water Reactor } \\
\text { Resource Conservation and Recovery Act }\end{array}$ \\
\hline
\end{tabular}


$\mathrm{RL}$

ROD

RSB

SAS

SISMP

SNF

SNFP

SPR

TPA

TRIGA

TRU

TWRS

WHC

WT\%

WIPP
U.S. Department of Energy, Richland Operations office Record of Decision

Reactor Service Building

Safeguards and Security

Site Integrated Stabilization Management Plan

Spent Nuclear Fuel

Spent Nuclear Fuel Project

Single Pass Reactor

Tri Party Agreement

Training Reactor, Isotopes, General Atomics

Transuranic

Tank Waste Remediation System

West inghouse Hanford Company

Weight Percent

Waste Isolation Pilot Plant 


\subsection{INTRODUCTION}

\subsection{BACKGROUND}

In May 1994, the Defense Nuclear Facilities Safety Board (DNFSB) issued DNFSB Recommendation 94-1 (Conway 1994), which identified concerns related to U.S. Department of Energy (DOE) management of legacy fissile materials remaining from past defense production activities. The DNFSB expressed concern about the existing storage conditions for these materials and the slow pace at which the conditions were being remediated. The DNFSB also expressed its belief that additional delays in stabilizing these fissile materials would be accompanied by further deterioration of safety and unnecessary increased risks to workers and the public.

In February 1995, DOE issued the DNFSB Recommendation 94-I Implementation Plan (0'Leary 1995) to address the concerns identified in DNFSB Recommendation 94-1. The Implementation Plan (IP) identifies several DOE commitments to achieve safe interim storage for the legacy fissile materials, and constitutes DOE's baseline DNFSB Recommendation 94-1 Integrated Program Plan (IPP). The IPP describes the actions DOE plans to implement within the DOE complex to convert its excess fissile materials to forms or conditions suitable for safe interim storage. The IPP was subsequently supplemented with an Integrated Facilities Plan and a Research and Development Plan, which further develop complex-wide research and development and long-range facility requirements and plans. The additions to the baseline IPP were developed based on a systems engineering approach that integrated facilities and capabilities at the various DOE sites and focused on attaining safe interim storage with minimum safety risks and environmental impacts.

Each affected DOE site has developed a Site Integrated Stabilization Management Plan (SISMP) to identify individual site plans to implement the DNFSB Recommendation 94-1 IPP. The SISMPs were developed based on the objectives, requirements, and commitments identified in the DNFSB Recommendation 94-1 IP. The SISMPs also supported formulation of the initial versions of the Integrated Facilities PIan and the Research and Development Plan. The SISMPs are periodically updated to reflect improved integration between DOE sites as identified during the IPP systems engineering evaluations. This document is the third update of the Hanford SISMP.

The Hanford SISMP includes plans to address DNFSB Recommendation 94-1 concerns related to management of SNF and plutonium-bearing materials at the Hanford Site. The following Hanford Site-related concerns were identified in DNFSB Recommendation 94-1:

- "The K-East Basin at the Hanford Site contains hundreds of tons of deteriorating irradiated nuclear fuel from the $N$ Reactor. This fuel has been heavily corroded during its long period of storage under water, and the bottom of the basin is now covered by a thick deposit of sludge containing actinide compounds and fission products. The basin is near the Columbia River. It has leaked on several occasions, is likely to leak again, and has design and construction defects that make it seismically unsafe." 
- "There are thousands of containers of plutonium-bearing liquids and solids at the Rocky Flats Plant, the Hanford Site, the Savannah River Site, and the Los Alamos National Laboratory. These materials were in the nuclear-weapons manufacturing pipeline when manufacturing ended. Large quantities of plutonium solutions are stored in deteriorating tanks, piping, and plastic bottles. Thousands of containers at the Rocky Flats Plant hold miscellaneous plutonium-bearing materials classed as "residuals", some of which are chemically unstable. Many of the containers of plutonium metal also contain plastic and, in some at the Rocky Flats Plant, the plastic is believed to be in intimate contact with the plutonium. It is well known that plutonium in contact with plastic can cause formation of hydrogen gas and pyrophoric plutonium compounds leading to a high probability of plutonium fires."

The plans in the Hanford SISMP have been developed consistent with the DNFSB recommendations, including the following recommendations directly affecting the Hanford Site:
"That the program be accelerated to place the deteriorating reactor fuel in the K-East Basin at the Hanford Site in a stable configuration for interim storage until an option for ultimate disposition is chosen. This program needs to be directed toward storage methods that will minimize further deterioration."
"That an integrated program plan be formulated on a high priority basis, to convert within 2-3 years the materials addressed in the specific recommendations below, to forms or conditions suitable for safe interim storage. This plan should recognize that remediation will require a systems engineering approach, involving integration of facilities and capabilities at a number of sites, and will require attention to limiting worker exposure and minimizing generation of additional waste and emission of effluents to the environment. The plan should include a provision that, within a reasonable period of time (such as eight years), all storage of plutonium metal and oxide should be in conformance with the draft DOE Standard on storage of plutonium now being made final."

Consistent with commitments in the DNFSB Recommendation 94-1 IP, schedule acceleration will result in removal of SNF from the $105 \mathrm{~K}$ East Basin (KE Basin) by December 1999 and will result in placement of plutonium-bearing materials at the Hanford Site Plutonium Finishing Plant (PFP) into safe interim storage by May 2002.

\subsection{PURPOSE}

This document comprises the Hanford SISMP. This document describes the DOE's plans at the Hanford Site to address concerns identified in DNFSB Recommendation 94-1. This document also identifies plans for other SNF inventories at the Hanford Site which are not within the scope of DNFSB Recommendation 94-1 because of their interrelationship with plans for SNF 
within the scope of DNFSB Recommendation 94-1. The SISMP was also developed to assist DOE in initial formulation of the Research and Development $\mathrm{Pl}$ an and the Integrated Facilities Plan.

\subsection{SCOPE}

Materials within the scope of this SISMP include SNF and plutonium-bearing materials currently located at the Hanford Site as identified in DOE's DNFSB Recommendation 94-1 IP. The Hanford SISMP is comprised of three volumes. Volume 1 provides the plans for placing the SNF and plutonium-bearing materials into safe interim storage, and Volume 2 provides integrated schedules for completion of the planned work scope identified in Volume 1. Volume 3 provides more detailed plans to address resolution of plutonium vulnerabilities.

\subsection{ORGANIZATIONAL RESPONSIBILITIES}

Multiple organizations will support implementation of planned activities identified in this SISMP. The U.S. Department of Energy-Headquarters (DOE-HQ) general organizational roles and responsibilities and interfaces with the DOE field offices for DNFSB 94-1-related activities are defined in the DNFSB 94-1 Implementation Plan (0'Leary 1995).

At the U.S. Department of Energy, Richland Operations Office (RL), the Spent Nuclear Fuel Project Division (SFD) has responsibility for the overall management, administration, and performance of the SNF Project to ensure the required levels of quality, safety, and environmental compliance are achieved within established technical, cost, and schedule baselines. The SFD is also responsible for management of the Hanford Site development of the SISMP and verifying performance to SNF related aspects of the SISMP schedule, cost, and technical baselines.

At present, the Westinghouse Hanford Company (WHC) SNF Project is responsible for developing technical, cost, and schedule baselines responsive to established requirements, implementing the $K$ Basins path forward and integrating interim storage activities for other Hanford SNF inventories. The WHC SNF Project is also responsible for developing the Hanford Site SNF related input to the SISMP and providing contractor input on performance of SNF related schedule, cost, and technical baselines to the RL SFD. Specific responsibilities and authorities for management of Hanford Site SNF activities are identified in WHC-SD-SNF-PMP-011, Hanford Site Spent Nuclear Fuel Project Management Plan (WHC 1995a).

The RL Transition Programs Division (TPD) has responsibility for management of PFP that is similar to SFD's responsibilities for SNF management. The TPD's PFP Transition Program Office provides oversight on the performance of WHC with respect to schedules, costs, and technical baseline for the RL Transition Programs Division. At present, the WHC PFP Transition Project provides the management and organization necessary for PFP to stabilize, store, and dispose of those materials covered by this SISMP until final disposition. The WHC PFP Transition Project ensures that PFP is managed in a safe, efficient, and environmentally sound manner to achieve the objectives of this SISMP.

Responsibilities and standards of operation required in the performance of all 
work at PFP are identified in WHC-CM-5-8, Plutonium Finishing Plant Administration, Volume 1.

The responsible RL and WHC Recommendation 94-1 Program Managers are as follows:

Spent Nuclear Fuel

$\begin{array}{lll}\text { RL } & \text { 0. M. Holgado } & 509-373-0589 \\ \text { WHC } & \text { R. L. McCormack } & 509-376-7057\end{array}$

Plutonium Bearing Materials

$\begin{array}{lll}\text { RL } & \text { D. W. Templeton } & 509-373-2966 \\ \text { WHC } & \text { T. E. Huber } & 509-373-1503\end{array}$

The WHC Management and Operations contract for the Hanford Site will expire at the end of Fiscal Year 1996 and be replaced by the Project Hanford Management Contract, which has been awarded to Fluor-Daniel Hanford Company. Duke Engineering \& Services Hanford, Inc. and Babcock and Wilcox Hanford Company will be the contractors responsible to Fluor-Daniel Hanford Company for most $k$ Basins and PFP stabilization activities, respectively. The Nuclear Material Stabilization Task Group will be informed of changes in organizational and individual responsibilities as they occur. These changes will also be reflected in the next update of the Hanford SISMP.

\subsection{SUMMARY}

The plans identified in the Hanford SISMP will result in removal of SNF from the K Basins by December 1999, consistent with the DNFSB's recommendation "That the program be accelerated to place the deteriorating reactor fuel in the K-East Basin at the Hanford Site in a stable configuration for interim storage until an option for ultimate disposition is chosen." Additionally, plutonium bearing materials will be placed in safe interim storage by May 2002. A summary schedule for planned activities is provided in Figure 1-1.

The remaining cost to achieve safe interim dry storage of the $K$ Basins SNF, including hot conditioning, is estimated at $\$ 321$ million. This cost is based on current budget estimates and includes the costs to retrieve, package, cold vacuum dry, transport, stage, condition and implement dry interim storage (i.e., characterize SNF, acquire facilities, etc.) and disposition $K$ Basins sludge. The projected cost to manage the $K$ Basins SNF until hot conditioning is completed is $\$ 497$ million. This cost includes operations at the $K$ Basins in addition to the costs to achieve safe interim dry storage. The $\$ 497$ million estimated cost does not include the program costs associated with $K$ Basins deactivation. These costs are based on remaining costs for the activities from the beginning of FY 1997 until completion.

The remaining cost to achieve safe interim storage of the plutonium-bearing materials is estimated at $\$ 124$ million. This plan assumes that DOE will reallocate resources to provide the budgets necessary to attain safe interim storage within schedule commitments.

The budget profiles are summarized in Table 1-1. 
Figure 1-1. Summary Schedule.

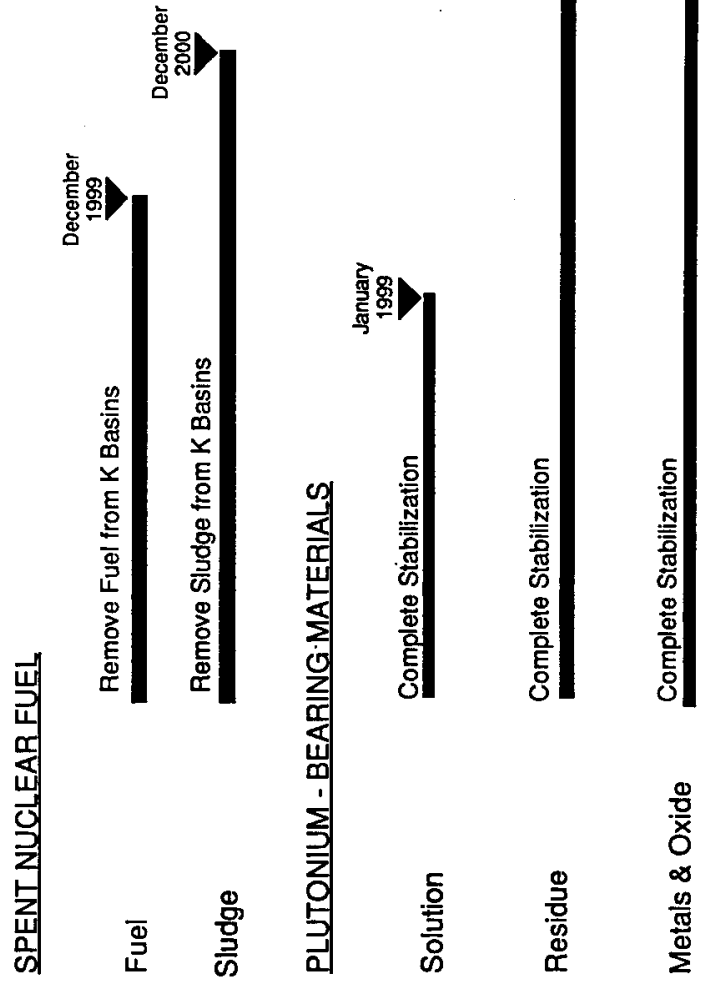




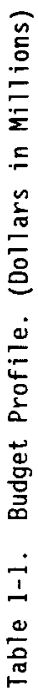

\begin{tabular}{|c|c|c|c|c|}
\hline & 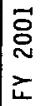 & $\stackrel{n}{\sim}$ & $\stackrel{0}{0}$ & $\stackrel{\infty}{\infty}$ \\
\hline $\begin{array}{l}\widehat{n} \\
\tilde{E} \\
\approx \\
\approx\end{array}$ & $\begin{array}{l}\text { S } \\
\text { S } \\
\text { } \\
\text { 너 }\end{array}$ & $\overrightarrow{0}$ & $\frac{m}{m}$ & $\Rightarrow$ \\
\hline $\begin{array}{l}\simeq \\
\frac{\pi}{\pi}\end{array}$ & $\begin{array}{l}\text { g } \\
\text { g } \\
\text { g } \\
\text { خ }\end{array}$ & $\stackrel{\infty}{\dot{\theta}}$ & $\ddot{n}$ & $\ddot{\sim}$ \\
\hline $\begin{array}{l}\stackrel{8}{0} \\
\frac{\dot{\theta}}{.}\end{array}$ & 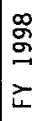 & $\stackrel{\sim}{N}$ & $\stackrel{\infty}{n}$ & $\overrightarrow{\text { Dे }}$ \\
\hline 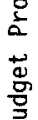 & $\begin{array}{l}\text { on } \\
\text { on } \\
\text { z }\end{array}$ & $\underset{\infty}{\infty}$ & $\stackrel{\infty}{\stackrel{\infty}{ \pm}}$ & $\underset{v}{\sim}$ \\
\hline$\frac{\dot{1}}{\stackrel{0}{\frac{0}{0}}}$ & & 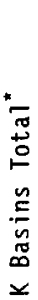 & 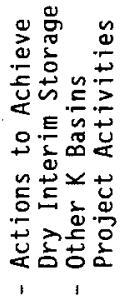 & 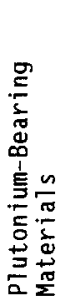 \\
\hline
\end{tabular}

$\stackrel{\leftrightarrow}{\complement}$

$\overbrace{0}^{\circ}$ in $\frac{0}{0}$

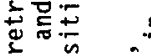

๘

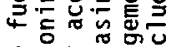

a 은

을 \pm 듬

늘뭉믈을

$\therefore$ 讨至

눌융연

的동ㄷㅇㅇㅢ

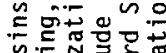

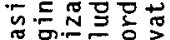

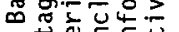

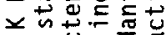

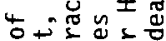

$0 \div \frac{1}{2}-\frac{1}{2}$

응은혼

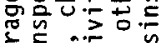

응

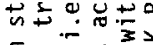

E

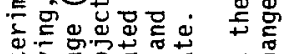

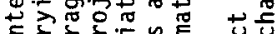

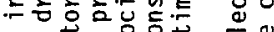

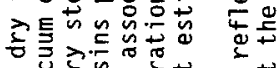

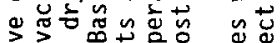

$\gg>\infty+\frac{0}{0}>\$$

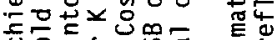

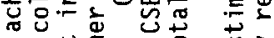

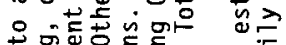

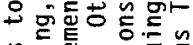

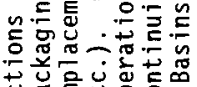

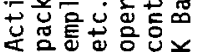

$\ddot{5} \frac{5}{\pi}$

路

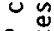

늠얼 


\subsection{HANFORD SITE SPENT NUCLEAR FUEL}

The Hanford Site's Spent Nuclear Fuel (SNF) Project was formed in early 1994 to manage the Hanford Site's SNF and to address the urgent need to move the SNF in the K Basins from its present degraded storage conditions to safe interim storage. Additionally, the SNF Project was chartered to integrate management of all SNF within the Hanford Site, to interface with the DOE-Owned Spent Nuclear Fuel Program, and to integrate Hanford Site SNF management with DOE complex-wide SNF management.

Activities conducted to manage Hanford Site SNF inventories are focused on remedying the DNFSB Recommendation 94-1 concern at the KE Basin. Consistent with SNF Project objectives and the DNFSB Recommendation 94-1 IPP systems engineering approach, plans to place other Hanford Site SNF into safe interim storage are being integrated with the KE Basin plans and with Hanford Site activities that manage other legacy materials. Additionally, all Hanford Site SNF inventories are included within the scope of the DOE-Owned Spent Nuclear Fuel Program, which is developing $\mathrm{plans}$ for integrated interim storage and technology development for all DOE-owned SNF.

Sections 2.1 and 2.2 of the Hanford SISMP identify DOE's plans for remedying near-term safety concerns and achieving safe interim storage of $K$ Basins SNF and other Hanford Site SNF, respectively. Issues and plans common to all Hanford Site SNF are addressed in Sections 2.3 through 2.5. Current Hanford Site SNF storage locations are shown in Figure 2-1. The SNF inventories at each facility, and current management concerns, are identified in Table 2-1.

More comprehensive descriptions of the current fuel storage facilities and the fuel inventories are available in WHC-SD-SNF-TI-001, Hanford Spent Fuel Inventory Baseline (Bergsman 1994).

\subsection{K BASINS SPENT NUCLEAR FUEL}

\subsubsection{Scope}

The scope of this portion of the Hanford SISMP includes plans to remedy the urgent safety concerns at the $K$ Basins and place the $K$ Basins SNF into safe interim storage. The KE and $105 \mathrm{~K}$ West (KW) Basins store approximately 2,100 metric tons of uranium (MTU) of defense (or "materia1s") production reactor SNF, primarity $N$ Reactor SNF. The K Basins inventory includes defense production reactor SNF which was transferred from the PUREX Plant to the KW Basin in October 1995. The inventory also assumes a small quantity of defense production reactor SNF (i.e., <0.5 MTU) could also be transferred from the $N$ Reactor Basins in 1996 during deactivation of that facility. Transfer of the PUREX Plant and $N$ Reactor Basins SNF inventories to the $K$ Basins is discussed in Section 2.2. 
Figure 2-1. Location of Hanford Spent Nuclear Fuels.

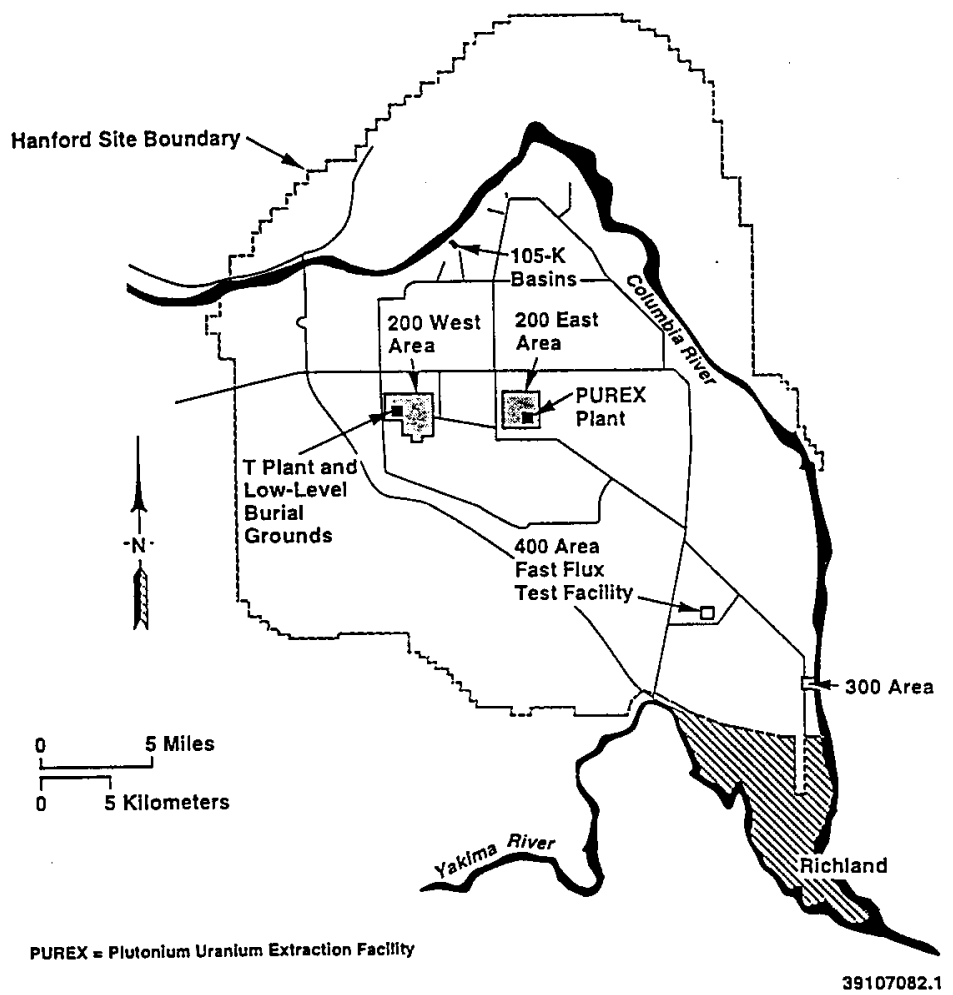




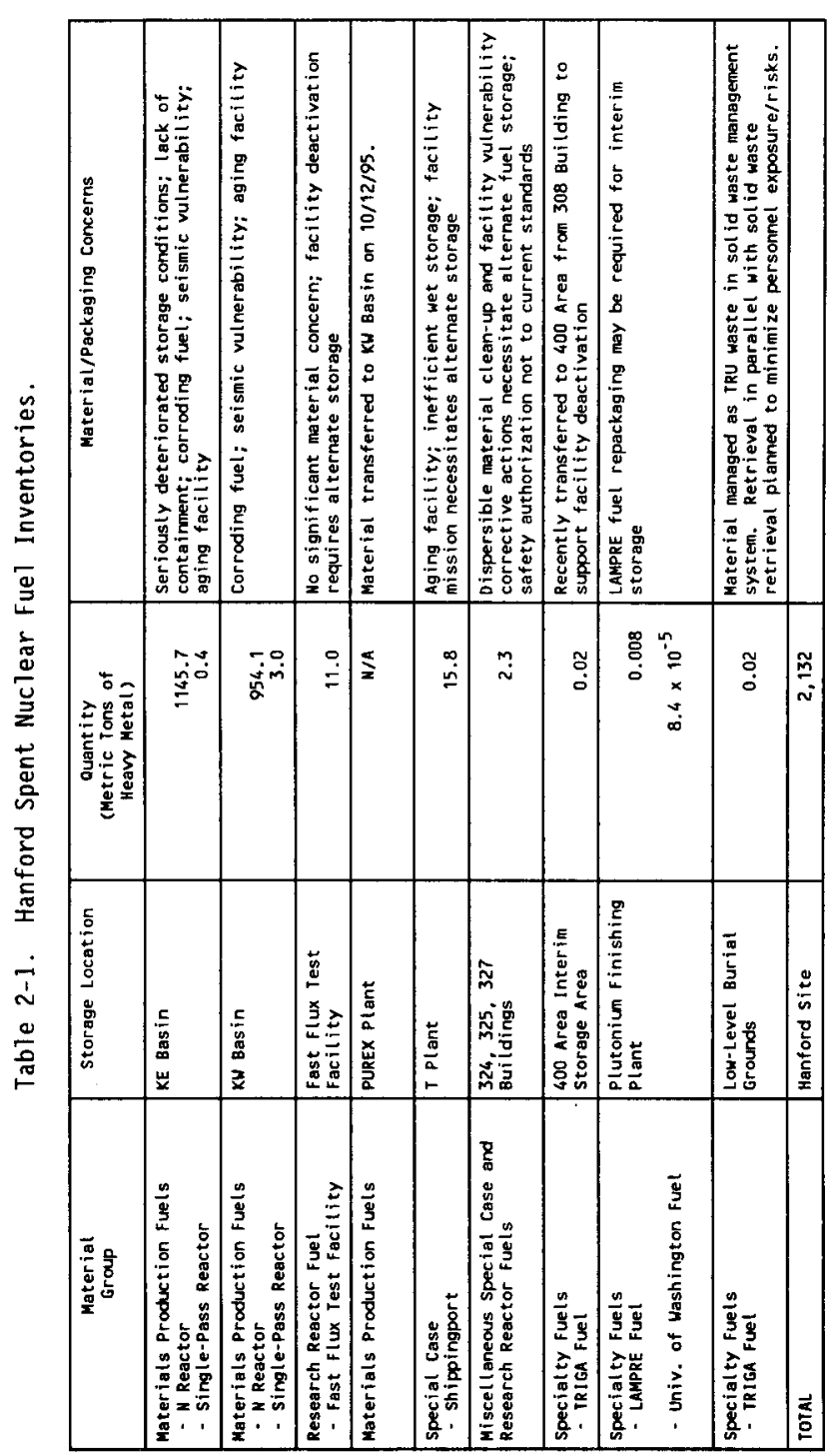




\subsubsection{Remediation Objective}

The objectives of the plans in this SISMP, in regard to management of $K$ Basins SNF inventories, are:

1) Resolve the safety and environmental concerns associated with the deteriorating SNF in the $K$ Basins, including those identified in DNFSB Recommendation 94-1 and in the November 1993 document, DOE Spent Fuel Working Group Report on Inventory and Storage of the Department's Spent Nuclear Fuel and other Reactor Irradiated Nuclear Materials and the Environmental, Safety, and Health Vulnerabilities (DOE 1993); and

2) Attain safe, environmentally sound, and economic dry interim storage of the $\mathrm{K}$ Basins SNF.

Safe dry interim storage for the $K$ Basins SNF will be attained when the SNF is stored in a manner that satisfies dry interim storage requirements for DOE-owned SNF as defined in the Office of Spent Fuel Management's Functions and Requirements Document (DOE 1994b) and that achieves nuclear safety equivalent to comparable Nuclear Regulatory Commission (NRC) licensed facilities.

\subsubsection{Remediation Process}

Fuel removal from the $K$ Basins and implementation of safe dry interim storage will be achieved consistent with the general approach identified in the October 1994 WHC report, WHC-EP-0830 (Fulton 1994), as refined by the integrated process strategy for $K$ Basins SNF approved by $R L$ in July 1995 (DOE 1995a). Sludge will be dispositioned consistent with the RL approved K Basins sludge disposition strategy (DOE 1995b), contingent on regulatory approval and ability to meet Tank Waste Remediation System acceptance criteria. The fuel and sludge removal process is depicted in Figure 2-2. Near-term safety and environmental concerns at the $K$ Basins will be addressed in parallel with long-term actions to achieve dry interim storage.

The primary steps of the remediation process are as follows:

- The K Basins SNF will be retrieved from current storage locations in existing canisters, cleaned to remove fuel corrosion particulate, placed in baskets, transferred in baskets to MultiCanister Overpacks (MCOS), and vacuum dried at low temperature to remove free water. The cold vacuum dried SNF, contained in MCOS, will be shipped to the 200 East Area for storage in the Canister Storage Building (CSB), which was originally designed and construction initiated for storage of vitrified high-level waste from the Hanford Waste Vitrification Plant. The SNF will also be dried at a higher temperature to remove bound water, and reactive sites on the surface of the SNF will be oxidized, as necessary, to reduce its chemical reactivity. The initial cold vacuum drying step will satisfy requirements for SNF removal from the $K$ Basins, consistent with the December 1999 commitment. The subsequent hot conditioning step will further improve the safety posture of storage at the CSB for the long-term ( 40 year) interim storage 
WHC-EP-0853 Rev. 3

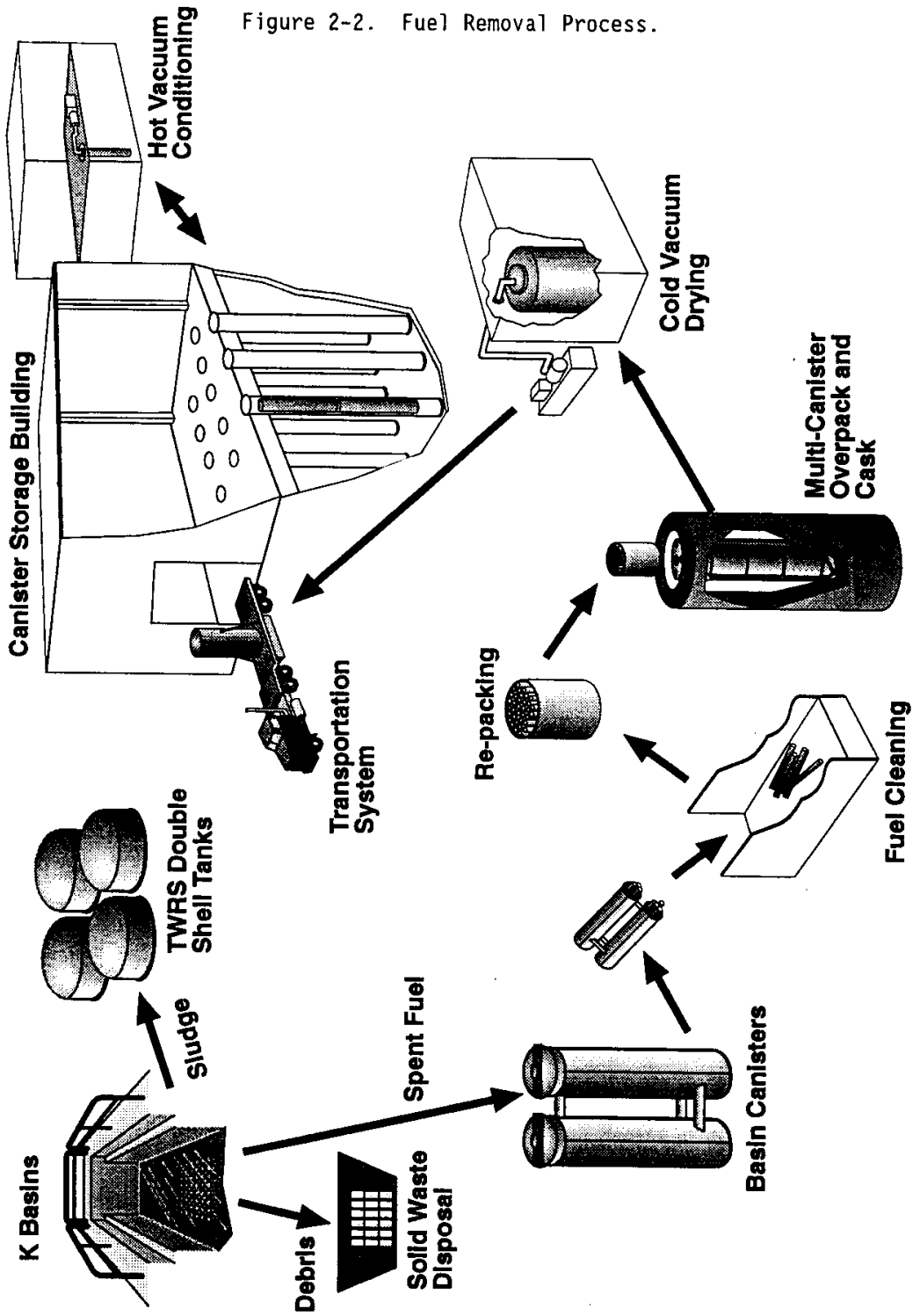


period. The hot conditioning step will be performed in an annex to the CSB and will be started by October 1998.

- KE Basin floor sludge, in addition to fuel corrosion particulate separated from fuel during fuel cleaning, will be accumulated at the KE Basin and later retrieved, characterized, and transferred to the 200 Area tank farms for disposition with tank farm waste, contingent on regulatory approval and ability to meet Tank Waste Remediation System acceptance criteria. Fuel corrosion particulate separated from fuel during fuel cleaning at the KW Basin will be collected on Ion Exchange Modules and later dispositioned as solid waste. The sludge and separated fuel corrosion particulate will be managed as SNF while at K Basins and until the determination is completed, based on characterization results, that the materials satisfy respective acceptance criteria at the receiving waste management facility.

After completion of the remediation process, the SNF will be stored at the CSB in a manner that results in nuclear safety equivalent to comparable NRC licensed SNF storage facilities.

To ensure the remediation process can be successfully completed within schedule commitments identified in the IPP, DOE has implemented the following project management strategy:

- Establish a dedicated DOE project office for executing the $K$ Basins SNF path forward and maximizing delegation of authority to the project office;

- Expedite project authorizations, including consolidation of key decisions;

- Establish a focused regulatory team and independent review team to streamline the process for establishing a safety authorization basis for the new storage system and achieving safety equivalence to comparable NRC-licensed facilities. The safety equivalence will be accomplished by applying technical requirements based on those applied by the NRC to comparable licensed facilities and by adopting appropriate features of the NRC licensing process, in addition to applicable DOE Orders and requirements.

2.1.3.1 Preparation. During the preparation period, the safety and environmental protection posture of the K Basins will be improved and systems will be acquired and readied to enable SNF and sludge removal. The major activities that will be completed during the preparation period are described in this section. Milestone identification numbers from Volume 2 of the SISMP are provided with the activity descriptions for cross-reference.

Readiness activities will be conducted as required to ensure compliance with DOE Order 425.1 and DOE-STD-3006-95. The readiness process will focus on the adequacy of physical systems, personnel, and the administrative process necessary to support and maintain safe operations. After the readiness 
process is completed and readiness is verified, written authorization to proceed with system operations will be provided by DOE to plant management.

The Plan of Action for SNF Project K Basin Fuel Removal Process Operational Readiness Review, Plan of Action for SNF Project Cold Vacuum Drying (CVD) Facility Operational Readiness Review, and Plan of Action for SNF Project CSB Operational Readiness Review define project plans to comply with DOE-STD-300693, DOE Order 425.1, and RLID 5480.31. The Plans of Action will formalize the decisions necessary to execute startup/restart of facilities required for SNF removal from the $K$ Basins. Each Plan of Action addresses the start/restart approval authority, breadth of readiness review, Operational Readiness Review prerequisites, readiness review leadership, preliminary startup schedule, startup decision point, and other elements necessary to formalize the process.

\section{Environmental Impact Statement}

The Environmental Impact Statement for Management of SNF from the $K$ Basins at the Hanford Site, Richland, Washington (K Basins EIS) was prepared and the record of decision (ROD) issued to satisfy National Environmental Policy Act (NEPA) review requirements for SNF and sludge removal from the $K$ Basins. The $K$ Basins EIS Notice of Intent was published in the Federal Register in March 1995 to fulfill requirements of "IP-3.6-015; Issue K Basins EIS Notice of Intent." The K Basins EIS ROD was issued in March 1996 to fulfill the requirements of "IP-3.6-010; Issue K-Basins EIS ROD."

The $K$ Basins EIS addresses actions for both removal of SNF and sludge from the $K$ Basins and SNF conditioning. Including both steps in the $K$ Basins EIS enables acceleration of SNF conditioning that would not have been possible with the two step NEPA review process recommended in WHC-EP-0830. The actions identified in this plan are consistent with the K Basins EIS ROD.

\section{Project Integration}

The project integration activity develops and maintains plans, including funding strategies and schedules, for acquiring systems required to implement the path forward for SNF removal from the $K$ Basins. An acquisition strategy and funding options were developed as an initial step in implementing the November 1994 approved path forward for fuel removal from the $K$ Basins to fulfill the requirements for completion of "IP-3.6-014; Develop K Basin potential funding options and acquisition strategy, as necessary."

An integrated schedule was issued, which reflected the acquisition strategy, to fulfill the requirements of "IP-3.6-020; Issue $K$ Basin integrated schedule detailing major systems acquisitions and material movements." Subsequent schedule refinements were completed to reflect the integrated process strategy and to reduce project schedule risks. The current baseline schedule is reflected in volume 2. The schedules will continue to be refined, as necessary, to support successful project execution.

\section{Systems Engineering}

The strategy to accomplish the Hanford SNF Project mission and objectives includes implementation of systems engineering. The SNF Project Systems 
Engineering Management Plan was developed to define implementation of systems engineering for the project. Additionally, the Hanford SNF Project technical baseline was developed and documented in the SNF Project Technical Baseline Description. The systems engineering activity will continue to maintain the project technical baseline and complete updates to the SNF Project Technical Baseline Description through the construction and startup of the systems and facilities.

\section{Process Engineering}

The process engineering activity is providing technical integration of the subprojects to achieve safe interim storage of the $K$ Basins SNF. These activities include development and maintenance of $K$ Basins SNF process flow diagrams, interface control, the $K$ Basins SNF dose management plan, and the Hanford SNF Integrated Safety Management Plan (ISMP).

The dose management plan provides a methodology for managing worker exposure for activities at the $K$ Basins and for each subproject related to SNF removal from the $K$ Basins. The ISMP identifies the safety authorization bases and permitting strategies for the subprojects.

\section{Technology Acquisition}

Technology is being acquired to achieve safe interim storage of $K$ Basins SNF on an aggressive schedule. As such, the projects to achieve safe interim storage are based on more robust, lower technology approaches that minimize technology development requirements. The technology acquisition activities are described in Section 2.1.8.

\section{Characterization}

$K$ Basins SNF and sludge are being characterized to acquire data necessary to implement their removal from the $K$ Basins. The K Basins SNF characterization is providing data on fuel oxidation, extent of fuel corrosion, reaction rates, and ignition temperatures that collectively will enable process design, establishment of safety bases, and operation of fuel retrieval, CVD, HCS, CSB, and transport systems. The $K$ Basins sludge characterization is providing data required for fuel cleaning, sludge drying and disposition, including data required to complete waste profile data sheets for sludge acceptance by the Tank Waste Remediation System or the Solid Waste Disposal Project.

Additionally, gas/liquid sampling of $\mathrm{KW}$ Basin canisters is being performed to acquire data for the Integrated Water Treatment system air permit.

These data are being acquired in campaigns to ensure data are available as necessary to satisfy IPP schedule commitments. Fuel characterization was previously initiated in the 300 Area hot cells to fulfill the requirements of "IP-3.6-018; Start K Basin fue] characterization in hot cells."

\section{$\underline{K}$ Basins Maintenance and Operations}

Maintenance and operations are being conducted at the $K$ Basins to ensure safe storage until completion of SNF and sludge removal and turnover of the facilities for deactivation. As part of the $K$ Basins Maintenance and 
Operations activity, a formal Conduct of Operations program has been established. The program will be maintained to ensure adequate safety performance during execution of activities at the $K$ Basins. $K$ Basins essential systems design reconstitution was also completed to improve safety performance for activities conducted at the $K$ Basins and to satisfy DOE Order 4700.1 requirements. The design reconstitution included development of $K$ Basins essential drawings and systems descriptions.

The K Basins Maintenance and Operations activity also included installation of seismic isolation barriers (e.g., cofferdams) between the KE Basin and the discharge chute to isolate the basin from the suspected leak site located in the unreinforced construction joint in the discharge chute. This action was completed to minimize the potential for environmental release of radioactive contaminants either directly through the leak into the ground or by airborne release, should the basin be drained as a consequence of a seismic event and the sludge dry to a powder. Basin draining and sludge dry-out could also result in significant radiological exposure to personnel during recovery actions. Similarly, seismic isolation barriers were installed at the KW Basin to reduce environmental and safety risks, although the consequences of leakage should be less than at the KE Basin due to fuel and sludge containment and water quality at the KW Basin. Physical installation and successful completion of acceptance testing of the seismic isolation barriers fulfilled the requirements of "IP-3.6-016; Complete cofferdam installation in KW Basin" and "IP-3.6-017; Complete cofferdam installation in KE Basin."

\section{K Basins Facility Projects}

$K$ Basins facility projects are being completed to ensure $K$ Basins facilities are adequate for continued safe operations and personnel protection during routine operations and activities to remove SNF and sludge from the K Basins. Essential facility systems recovery actions are being completed for electrical, potable water, fire protection, and maintenance systems. Roof repairs have been completed. Supplemental facilities are being provided for maintenance and basin loadout personnel.

\section{Dose Reduction}

Activities are being completed to reduce personnel exposure during current and planned operations, maintenance and construction activities in keeping with as-low-as-reasonably-achievable (ALARA) practices. Dose reduction is being implemented by reducing the radioactive source term from cesium-contaminated concrete basin walls and pipe runs in the $K$ Basins, executing the dose management plan, and incorporating dose reduction features into designs.

Significantly, cleaning and coating of the KE Basin wall "bathtub ring" was completed and the water level raised. An $80 \% \mathrm{KE}$ Basin background dose reduction was achieved from the time cleaning and coating was completed to after the water level was raised to $16^{\prime} 10^{\prime \prime}$.

\section{Fuel Retrieval}

Systems are being acquired and will be readied for operations in the KE and KW Basins to retrieve SNF from existing storage, remove the SNF from existing 
canisters, remove fuel corrosion particulate from the SNF to the extent necessary to satisfy dry storage and transport requirements, and piace the SNF into baskets for transfer into MCOs. Major activities include detailed design, fuel retrieval system testing, system procurement, and installation.

\section{Water Treatment}

An Integrated Water Treatment (IWT) system is being acquired to improve water cleanup at the KE and KW Basins. The IWT system will include separate systems at each basin, with different designs to accommodate differences in sludge and fuel corrosion particulate sources. The IWT system will provide "clean" water for in-basin operations to ensure visibility during fuel retrieval operations, reduce worker dose during $K$ Basins operations, and to reduce carryover of contamination to the MCOS and downstream facilities. The IWT system activity includes design, permitting, procurement, and installation of the systems at each basin.

\section{MCO Acquisition}

$K$ Basins MCOs will be acquired to provide confinement/containment of the $K$ Basins SNF during onsite transport, cold vacuum drying, staging, hot conditioning, and interim storage. The activity includes design, testing, and procurement of $400 \mathrm{MCOs}$ for SNF storage. The testing activity includes fabrication and testing of prototype MCOs, baskets, and components. Additionally, a Topical Safety Report will be developed to establish the safety basis for MCO related operations.

Phase I design of the MCOs was completed to support fabrication of the prototype MCOs for testing. Two types of closures, mechanical and weided, are being tested to support selection of a final MCO closure design. Additional testing, such as thermal cycling and vibration testing, is being completed to support final design. Mark IA and Mark IV basket prototypes have been fabricated and tested to support final design of the baskets. Phase 2 design will be initiated after prototype testing to support fabrication of the MCOs for SNF storage.

\section{Cask/Transport System}

The $K$ Basins SNF cask transport system is being acquired to enable onsite shipment of MCOs from the 100 Area to the CSB. The activity includes: modifications at the $K$ Basins for cask handling; procurement of five casks, transport vehicles, and MCO loading equipment; and issuance of a Safety Analysis Report for Packaging for onsite shipment of the casks.

\section{Canister Storage Facility}

The CSB is being acquired to provide for a location for safe interim storage of the K Basins SNF until final disposition. The CSB acquisition activities are being phased to support the aggressive construction schedule. The major phases of the CSB include acquisition of the CSB substructure, the deck, and the superstructure. The activity also includes acquisition of the MCO Handling Machine (MHM) and other CSB supporting equipment/systems. Most concrete placement has been completed for the CSB vault structure. 
Sludge Removal

Systems will be acquired and readied for operations at the $K$ Basins to remove sludge and fuel corrosion particulate from the $K$ Basins, consistent with the $K$ Basins sludge path forward. The fuel corrosion particulate that will be addressed is comprised of the fuel corrosion products within the fuel canisters that are separated from the fuel during fuel cleaning to reduce the amount of free and bound water within an MCO. The sludge on the K Basins floors is believed to consist of blow sand, structural material oxides, and concrete spallation products.

The sludge path forward is being integrated with $K$ Basins debris removal, water treatment, and fuel retrieval due to the interrelationship of the activities. The recommended path for disposition of KE Basin fuel corrosion particulate and sludge is at the Tank Waste Remediation System (TWRS), pending verification that the materials satisfy TWRS acceptance criteria. The planned disposition path for KW Basin fuel corrosion particulate is collection on Ion Exchange Modules in the IWT system during fuel retrieval and subsequent transfer to solid waste disposal.

As an initial step in assessing sludge retrieval and to support cofferdam installation, sludge was transferred from the discharge chute in the KE Basin during the cofferdam installation. Completion of this activity fulfilled the requirements of "IP-3.6-019; Initiate sludge retrieval demonstration in conjunction with cofferdam installation."

\section{Debris Removal}

As part of $K$ Basins cleanup activities, debris removal activities are being conducted. The debris is comprised of various materials, such as unused canisters and discarded tools. Canisters accumulated at the KE Basin are currently being washed and transferred to a private contractor for compaction and subsequent transfer to solid waste disposal. Canisters emptied during fuel retrieval will be similarly dispositioned.

\section{Fuel Conditioning}

Fuel conditioning includes acquisition and operation of the CVD system to support SNF removal from K Basins and the HCS to improve the safety posture for long-term storage of the SNF by removing bound water. The hot conditioning system will be acquired in parallel with activities to remove SNF from the $K$ Basins, but will not be available during initial SNF removal operations.

The CVD system will be located within the 100-K Area, west of the KW Basin. The CVD system will include four stations for cold vacuum drying of the SNF within MCOs. Cold vacuum drying will be performed at $50{ }^{\circ} \mathrm{C}$ to remove free water from the MCOs for onsite transport and staging at the CSB. The temperature will then be elevated to $75{ }^{\circ} \mathrm{C}$ to satisfy safety authorization basis requirements for onsite transport of the loaded MCOs. 
The hot conditioning facility will be an annex to the CSB to minimize fuel handling requirements and system costs. An option was inciuded in the CSB construction contract for construction of the hot conditioning facility to recognize economies and enhance schedule for completing acquisition of the hot conditioning system.

2.1.3.2 Production. Fuel removal will be initiated in December 1997 and completed in December 1999 . The production phase for fuel removal will include operational activities to retrieve, package, cold vacuum dry, and transport the SNF and emplace the SNF into the CSB. The fuel removal phase does not include hot conditioning of the SNF. Initial fuel removal will be performed at the KW Basin to optimize production activities in an environment with low radiological exposure prior to full scale production in both basins. Initiation of fuel retrieval activities in the $\mathrm{KW}$ Basin will fulfill the requirements of "IP-3.6-012; Begin SNF and sludge removal from $K$ Basins. Removal of all SNF in canisters in storage racks from the $K$ Basins will fulfill the requirements of "IP-3.6-001; Complete fuel removal from K Basins."

Sludge and fuel corrosion product removal from the $K$ Basins will be completed by December 2000 . These materials at the KE Basin will be accumulated in the KE Basin weasel pit during fuel retrieval operations and later transferred to a transport package. Samples will then be acquired and analyzed. Assuming TWRS acceptance criteria are satisfied, these materials will be transported to the 200 Area and transferred to underground storage tanks for disposition with existing tank waste. The fuel corrosion product separated from the fuel at the KW Basin will be collected on Ion Exchange Modules and subsequently dispositioned as solid waste, assuming solid waste acceptance criteria are satisfied. Approximately 52 cubic meters of sludge and fuel corrosion particulate will be removed from the $K$ Basins. Completion of the sludge removal campaign will fulfill the requirements of draft milestone "IP-3.6-201; Complete removal of all sludge from the K-Basins."

Hot conditioning will be conducted beginning in October 1998. For hot conditioning, a loaded MCO will be removed from a storage tube and transferred to a hot conditioning station located in the annex to the CSB. The SNF wi11 be conditioned at an elevated temperature within the MCO to remove bound water. The MCO will then be returned to a storage tube within the CSB vault. The schedule duration for hot conditioning operations will be finalized by October 1996. The cost and schedule estimates within the SISMP assume a two year production period for hot conditioning, pending finalization of a schedule for hot conditioning operations. 


\subsubsection{Schedule Objectives}

Consistent with the IPP, the schedule objective for relocating $K$ Basins SNF to safe, compliant storage is December 1999 or earlier. Additionally, SNF removal from the $K$ Basins will be initiated by December 1997. To reflect the integrated process strategy for fuel removal from the $K$ Basins, a separate milestone to complete sludge removal from the $K$ Basins by December 2000 has a] so been proposed to supplement the existing IPP schedule commitments.

Schedule commitments identified in the IPP to remedy seismic concerns at the $K$ Basins and to ensure early progress on the path forward for fuel removal from the $K$ Basins have been satisfied on or ahead of schedule. These IPP commitments include:

- Develop potential funding options and an acquisition strategy as appropriate by the end of March 1995.

- Issue Notice of Intent for K Basins EIS in March 1995.

- Complete cofferdam installation in K West Basin by February 1995 and in K East Basin by April 1995.

- Start fuel characterization in hot cells by April 1995.

- Initiate sludge retrieval demonstration in conjunction with cofferdam installation by April 1995.

- Issue a K Basins integrated schedule by May 1995 that includes the following:

- Complete NEPA process;

- Submit project validation package;

- Initiate development for $N$ Reactor fuel conditioning process;

- Finalize site identification and initiate site characterization for facilities;

- Place contract(s) for necessary equipment and facilities;

- Begin fuel removal from K Basins;

- Design MCOs;

- Begin MCO manufacture;

- Start and complete construction of CSB;

- Start and complete construction of conditioning facility;

- Start and complete fuel conditioning;

- $\quad K$ Basin fuel in dry storage.

The IPP also required issuance of the $K$ Basins EIS Record of Decision by December 1995. The Record of Decision was issued in March 1996.

To ensure that the schedule commitment to initiate SNF removal from the $k$ Basins is not impacted by late issuance of the Record of Decision, multi-shift construction of the CSB and an innovative CSB construction approach are being implemented. These actions are reflected in the schedule provided in Volume 2. 
In addition to the existing IPP commitments, DOE has proposed supplemental schedule commitments to the DNFSB based on the $\mathrm{K}$ Basins integrated schedule. The commitments will be formalized with the next annual IPP revision.

Proposed supplemental schedule commitments that have already been satisfied include the following:

- Initiate fuel drying/conditioning testing by May 1995

- Award cask/transport design purchase order by January 1996

- Award CSB construction contract by January 1996

- Complete site evaluation study for cold vacuum drying by February 1996

- Authorize Key Decision 3B for CSB construction by March 1996

- Start construction of CSB by March 1996

- Present cold vacuum drying system design Critical Decisions - 1/2 package by April 1996

- Present cask design Critical Decisions - 1/2 package by October 1996

These proposed commitments were all satisfied on or ahead of schedule.

Proposed supplemental schedule commitments that remain to be completed include the following:

- Authorize fuel retrieval system procurement (i.e., Critical Decision-3) by October 1996

- Establish a commitment date for completion of hot conditioning system operation by October 1996.

- Award MCO fabrication contract by June 1997

- Issue MCO Phase II design review report by June 1997

- Start fabrication of initial MCO order by June 1997

- Complete construction of CSB by November 1997

- Begin construction of hot conditioning facility by December 1996

- Complete process equipment installation for hot conditioning system by July 1998

- Start hot conditioning system operation by October 1998 
The proposed completion dates for three of the activities, "Award MCO fabrication contract", "Start fabrication of initial MCO order", and "Begin construction of hot conditioning facility," have been extended from the initially proposed dates, which were reflected in the previous Hanford SISMP revision. The changes are needed to accomodate resolution of technical issues that emerged on the MCO design (i.e., pressure management) and CSB design. The critical path to initiate SNF removal from the $K$ Basins and to initiate hot conditioning are not impacted by these changes.

Schedule commitments identified in the October 1994 document, Plan of Action to Resolve Spent Nuclear Fuel Vulnerabilities (Phase III) (DOE 1994a) will also be satisfied.

\subsubsection{Assumptions}

The scope, schedule, and costs identified in the Hanford SISMP for $K$ Basins SNF plans are based on several key assumptions:

- The technical scope and approach to implement the path forward for fuel removal from the $K$ Basins will be consistent with the general technical approach identified in the integrated process strategy.

- KE Basin sludge and fuel corrosion particulate will be dispositioned at the Tank Waste Remediation System.

- Budget and manpower resources will be available in support of critical path activities.

- Current onsite transportation requirements will not change.

- Resource Conservation and Recovery Act (RCRA) permitting and NRC 7 icensing (or NRC review) will not be required for new storage or conditioning systems required to implement the path forward for fuel removai from $K$ Basins.

- Current safeguards and security requirements identified in DOE Order 5333.2 will not change.

\subsubsection{Issues and Problems}

Critical issues that must be resolved to identify or implement actions at the Hanford Site and items that could limit schedule performance for $K$ Basins SNF include:

- Final resolution of requirements for NRC equivalency for tornado hardening and seismic design of the CSB deck and superstructure must be achieved during September 1996 in a manner that does not impact the construction completion schedule.

- While removal of basin sludge is no longer on the critical path for SNF retrieval, the ability of the sludge to meet TWRS 
acceptance criteria must be demonstrated to satisfy schedule commitments for sludge removal.

- Startup planning and Operational Readiness Reviews must continue to support the planned startup of operations and be completed in parallel with final construction activities.

- Adequate funding levels for Hanford Site SNF management must be maintained.

\subsubsection{Alternatives}

A formal systems engineering process is being used to establish and maintain a technical baseline for SNF management. The functions and requirements developed by the Hanford Site systems engineering process are based on site-specific requirements and high-level SNF management requirements established by the DOE Office of Spent Fuel Management. The Hanford SNF Project technical baseline and functions and requirements are identified in WHC 1995c.

The systems engineering process resulted in identification of the following alternatives for the $K$ Basins fuel removal path forward:

Alternative 1: Alternative l overpacks the fuel stored in the KE Basin and maintains storage of overpacked fuel at KE Basin and encapsulated fuel at KW Basin until a fuel conditioning and interim storage system is available. For comparison purposes, the fuel conditioning process is assumed to be based on repackaging and passivation of the fuel once it is received in the Fuel Conditioning Facility. The repackaged/passivated fuel is then transferred to an interim storage facility that is assumed to be based on a vault storage concept. This alternative also includes upgrading the existing $K$ Basins (retrofit and life extension).

Alternative 2: Alternative 2 overpacks the fuel stored in both $K$ Basins and transfers the overpacked fuel to a wet pre-interim (an existing facility modified for wet storage), or to a new wet storage facility. The fuel is stored in this wet storage facility until a conditioning and interim storage system is available. For comparison purposes, the fuel conditioning process is assumed to be based on a fuel passivation concept proposed by a DOE independent technical assessment team. The process transfers the fuel from the overpacks selected for the pre-interim wet storage to the package configuration developed for the passivation system, within the pre-interim wet storage facility. The repackaged fuel is then transferred to the Fuel Conditioning Facility for passivation. The passivated fuel is then transferred to the dry interim storage facility that is based on a vault storage concept. In this alternative, the principal driver is the prompt removal of the SNF from the $K$ Basins to another location for some period of pre-interim wet storage.

Alternative 3: Alternative 3 uses the passivation process identified in Alternative 2, without pre-interim wet storage. This alternative offers 
a possible method of early SNF conditioning with a potential for early achievement of interim dry storage. The SNF processing may be performed within a new addition to the $K$ Basins or at a location associated with the dry interim storage facility.

Alternative 4: In this alternative, custody of the packaged SNF is transferred to a foreign enterprise that assumes responsibility for transoceanic transport and for processing to stable residues (conditioned wastes). In the preferred configuration, the residues are returned to the Hanford Site for interim dry storage to await final disposition. Alternative 4 includes packaging $N$ Reactor SNF, assumes shipping the fuel to the British Nuclear Fuel Laboratories' Sellafield Plant located in the United Kingdom, and assumes processing the fuel at the Sellafield Plant and return of the residues to the Hanford Site for interim dry storage. The low- and intermediate-level wastes would be retained in the United Kingdom. Primary options within this alternative include: (1) shipping of unencapsulated damaged fuel in a British Nuclear Fuel Laboratories' cask instead of containerization of damaged fuel prior to cask loading; and (2) retention of conditioned waste/residue in the United Kingdom instead of returning it to the Hanford Site for interim dry storage.

The $K$ Basins path forward alternatives were evaluated using a multi-attribute decision process as described in the Westinghouse Hanford Company report WHC-EP-0830 (Fulton 1994). The evaluation process included scoping analyses of cost, schedule, safety and regulatory orivers; normalization of key assumptions and the bases for comparison; independent assessments by outside experts; and the use of decision analysis techniques to assure a comprehensive, balanced treatment of the pros, cons and uncertainties associated with the various alternatives. An important aspect of this process was the identification of vulnerabilities, their potential impacts and how they might be mitigated. For example, the impacts on related issues such as disposal of the water and debris, worker exposure, minimizing the cost and risks of continued operations in the $K$ Basins, etc., were considered in selecting the recommended path forward.

The evaluation process resulted in selection of the path forward identified in the Hanford Site SISMP, which combines the best attributes of the various alternatives to accelerate fuel removal from the $K$ Basins. DOE formal approval of the path forward is documented in Lytle (1994). Subsequent assessments have resulted in refinements to plans defined in the path forward, as reflected in the work scope, costs and schedules identified in the SISMP. Notably, the integrated process strategy (WHC 1995b) was developed to define an integrated approach for fuel removal, transport, staging, conditioning, and dry storage of the $K$ Basins SNF. Additionally, the potential environmental impacts of the above alternatives were evaluated in the $K$ Basins EIS, which resulted in a Record of Decision consistent with the plans identified in the SISMP.

Alternatives considered in the $K$ Basins path forward decision process will not enable fuel removal from the KE Basin within 2-3 years, but will satisfy schedule commitments identified in the IPP. Actions to improve the safety 
posture at the basin, such as installation of seismic isolation barriers, will reduce the risk of continued storage beyond three years.

\subsubsection{Technology Devel opment}

Technology is being acquired to support the various activities to achieve dry interim storage of the K Basins SNF. The acquired technology is generally used to support design decisions and development of safety authorization bases.

The technology acquisition activity has developed baseline recommendations which are incorporated into the integrated process strategy and subsequent activities. Position papers have been developed on chemical reactivity for interim use in analyses, pending publication of further $K$ Basins specific data. A basic approach for engineered management of potential fuel pyrophoricity has been developed relying on control of air ingress to 1 imit reactive phenomena. Radiologic decomposition has been modeled for various design options. Oxygen gettering has been studied, with design recommendations developed. General degradation of the fuel condition, described by effective surface area has been developed. Finally, hydrogen detonation modeling basics have been established.

Detailed models are being used in the analysis to predict the thermal and pressure response of the integrated system ( $M C O$ and cask or MCO and CSB) for operational and accident transients. Models for MCO internal convective, conductive and radiative heat transfer have been incorporated, as have been chemical reaction rate equations, hydrate and hydride decomposition equations, radiolysis equations and decay heat relationships. These models are extended to integrate with release modeling and dose modeling, for those accidents which have the potential for release of fission products.

The focus of technology activities is now integration of existing information and resolution of progressively prioritized issues to support design refinement and safety analysis. Toward this end, a key activity is a systematic review of the developed models to ascertain sensitivity to various assumptions, followed by systematic confirmation these assumptions have been resolved. Key areas of focus, based on initial parametric studies, include reduction in the uncertainties on $N$ Reactor SNF chemical reactivity, corrosion product composition, hydrate decomposition under process conditions and effective surface area of corroded fuel.

Technology acquisition activities are being integrated with development activities at other DOE complexes through the office of Spent Fuel Management's Technology Integration Technical Working Group. The cost of technology acquisition for the $K$ Basins SNF is included within Table 2-2. Schedule and cost risks for SNF removal from the $K$ Basins resulting from technology acquisition activities have been significantly reduced through decisions to desludge, repackage, and cold vacuum dry the $K$ Basins SNF prior to transport to the CSB. 


\subsection{OTHER HANFORD SITE SPENT NUCLEAR FUEL}

\subsubsection{Scope}

Plans to attain safe interim storage for Hanford Site SNF that is currently located at facilities other than the K Basins (i.e., "other SNF") are included in the SISMP for information, due to the potential for utilizing common facilities with DNFSB Recommendation 94-l materials at the Hanford Site and other DOE sites. The facilities where the other SNF inventories are currently located and the respective facility missions are as follows:

- The T Plant, which serves as a beta-gamma decontamination facility and provides other solid waste management services in addition to storage of Shippingport Pressurized Water Reactor (PWR) Core 2 fuel.

- The Fast Flux Test Facility (FFTF), which provided testing capability for the U.S. fast breeder reactor program, notably irradiation and evaluation of different types of fuel assemblies and materials for fuel assembly construction. The FFTF also produced materials such as medical isotopes. The FFTF test mission recently ended and the facility is currently implementing deactivation plans.

- The 400 Area Interim Storage Area, which is adjacent to the FFTF. The 400 Area ISA includes a concrete storage pad, fencing, and lighting for cask storage of SNF. Currentiy six Neutron Radiography Facility (NRF) Training Reactor, Isotopics, General Atomics [TRIGA] SNF casks and two Department of Transportation Specification 6M containers are stored in a vault at the 400 Area ISA. Additionally, cask storage of FFTF SNF at the 400 Area ISA pad has been initiated.

- The 325 Building Shielded Analytical Laboratory (and 325-A Radiochemical Facility), which support process demonstration and analytical chemistry requirements for a variety of DOE programs.

- The 324 Building, which is a shielded chemical processing laboratory used for development of chemical processes from laboratory to pilot scale and for examination and mechanical testing of irradiated specimens. The 324 Building contains laboratory, support facilities, and office space.

- The 327 Building, also known as the Post-Irradiation Testing Laboratory (PITL), which provides shielded, ventilated, and specially equipped laboratories for physical and metaliurgical examination and testing of irradiated fuels, concentrated fission products, and structural materials. The long-term mission of the facility is not certain. Near-term activities at the 327 Building include SNF characterization.

- The PFP in the 200 West Area, which supported plutonium metal production for the defense program. PFP is described in Section 
3.0. SNF at PFP is currently stored at the 2736-ZB storage vault and in a storage module in the yard area.

- The 200 Area Low-Level Burial Ground (LLBG), which supports management of solid waste materials at the Hanford Site. The SNF at the LLBG is being managed consistent with requirements for remote-handled transuranic waste per DOE Order 5820.2A.

Legacy defense production reactor SNF (i.e., N Reactor and Single-Pass Reactor SNF) was previously stored at the Plutonium-Uranium Extraction (PUREX) Plant. The PUREX Plant SNF inventory was shipped to the KW Basin in October 1995 and will be managed consistent with the other $K$ Basins SNF inventory.

Additionally, up to 0.5 metric tons heavy metal of $N$ Reactor SNF may be remaining in the sludge at the floor of the $N$ Basins. SNF recovered during $N$ Basins deactivation will be transferred to the KW Basin for consolidated management with other $\mathrm{N}$ Reactor SNF.

The inventories and storage concerns associated with the other Hanford Site SNF inventories were identified previously in Table 2-1. A brief description of the facilities is provided in Appendix A.

\subsubsection{Remediation Objective}

The objectives of the plans in this SISMP for other Hanford Site SNF inventories are to:

1) Complete interim actions to remove fuel from existing facilities to support current facility missions and corrective actions to vulnerabilities identified in the November 1993 document, DOE Spent Fuel Working Group Report on Inventory and Storage of the Department's Spent Nuclear Fuel and other Reactor Irradiated Nuclear Materials and the Environmental, Safety, and Health Vulnerabilities (DOE 1993); and

2) Attain safe, environmentally sound, and economic interim storage of all Hanford Site SNF pending establishment of a national SNF strategy and criteria for final disposition of DOE-owned SNF.

Interim actions will be performed and vulnerability corrective actions completed as identified in the October 1994 DOE document, P7an of Action to Resolve Spent Nuclear Fuel Vulnerabilities (Phase III) (DOE 1994a). Safe interim storage for the other Hanford Site SNF inventories will be attained when these materials are stored in a manner that satisfies dry interim storage requirements for DOE-owned SNF as defined in the Office of Spent Fuel

Management's Functions and Requirements Document (DOE 1994b).

\subsubsection{Remediation Process}

The near-term management and interim storage activities will be integrated to minimize SNF handling and resultant exposure and waste generation. Actions to attain safe interim storage of other Hanford SNF inventories are consistent with the settlement agreement (Idaho 1995) between the U.S. Department of the 
Navy, DOE, and the State of Idaho on the Record of Decision for the DOE Programmatic SNF Management and Idaho National Engineering Laboratory Environmental Restoration and Waste Management Programs Environmental Impact statement. The settlement agreement will result in continued storage of the other Hanford SNF inventories at the Hanford Site until preparation for final disposition, except for sodium bonded FFTF SNF which will be transferred to Argonne National Laboratory-West (ANL-W) for treatment after December 2000.

Plans for management of the other Hanford SNF are depicted in Figure 2-3. These actions include near-term consolidation of most SNF currently in the 300 and 400 Areas at the 400 Area ISA to support deactivation missions and vulnerability corrective actions at the FFTF and the 324/325/327 Buildings. After construction of the CSB, a 200 Area ISA will be installed adjacent to the CSB. The SNF at the 400 Area ISA and most 200 West Area SNF will be transferred to the 200 Area ISA or to the CSB to minimize storage costs and enable deactivation of 400 Area facilities. The CSB will be used to transload SNF for transfer off-site, as final disposition is implemented. SNF requiring enhanced safeguards and security will be stored at PFP.

\subsubsection{FFTF SNF. The FFTF SNF inventory will be removed from in-sodium} storage at the FFTF to enable facility deactivation. The SNF will be transferred from FFTF to one of three near-term locations dependent on the SNF characteristics.

Most FFTF SNF will be washed in the FFTF Interim Examination and Maintenance (IEM) Cell to remove sodium. The assemblies will then be placed in unshielded Core Component Containers (CCC's) made from stainless steel and Inconelo. A bottom loading shielded fixture called the Solid Waste Cask will be used to remove each CCC from the IEM Cell and take the CCC to the adjacent Reactor Service Building (RSB), where each CCC will be inserted into an FFTF Interim Storage Cask (ISC) that has been previously loaded into the Cask Loading Station.

A CCC is designed to hold six assemblies or pin containers. By removing the stainless steel end portion of an assembly, a seventh assembly will be added to each CCC, provided that the decay heat of the SNF placed in the CCC does not exceed 1,500 watts. Only six pin containers may be $p l a c e d$ in a CCC. Approximately 50 ISC's will be required by implementing this approach. An ISC consists of a steel inner container bonded to concrete shielding using weld studs. The ISC's will function as secondary confinement. After each ISC is closed, the ISC will be inerted and moved to the adjacent 400 Area ISA. The 400 Area ISA pad is surrounded by a locked fence and lighting fixtures.

Sodium bonded FFTF SNF will be shipped to ANL-W in T-3 Casks for consolidation with similar SNF. The sodium bonded FFTF SNF will be initially stored in ISC's and later transloaded into T-3 Casks at the CSB. The DOE Certificate of Compliance for the T-3 Cask is being amended to accommodate full assemblies or an increased number of pins to curtail the number of shipments to ANL-W. The total number of SNF shipments will be eight, consisting of six assemblies and two pin containers. 
Figure 2-3. Hanford Site Spent Nuclear Fuel Flow Diagram.
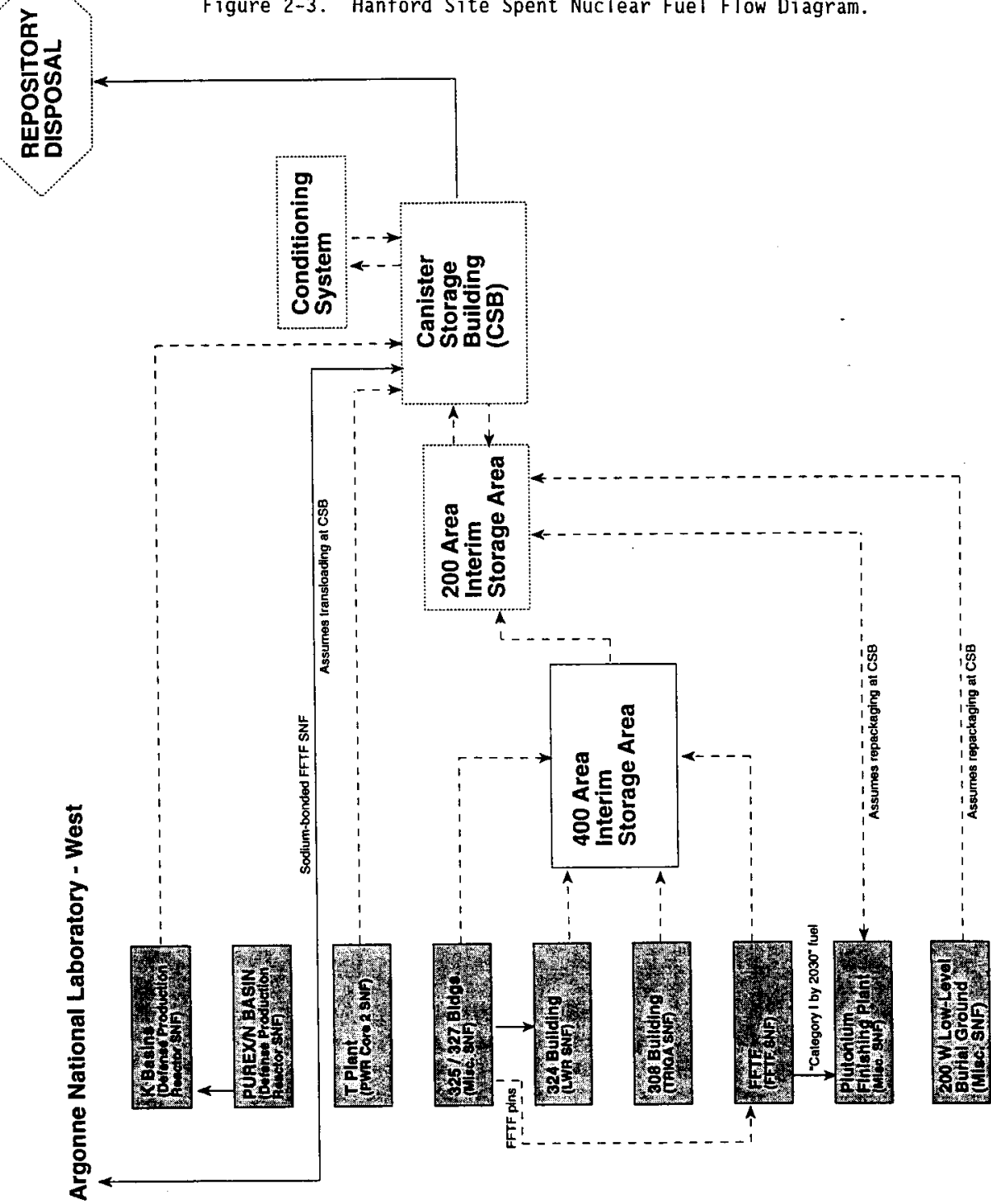
Two or three ISC's will be placed inside the protected area at PFP to satisfy safeguards requirements. The ISC's will be shipped directly to PFP after 1rading and will not be stored at the 400 Area ISA.

The initial ISC was delivered in June 1995 and nine casks were loaded by August 1996. The last ISC is scheduled to be placed on the 400 Area ISA pad in late 1998. The ISC's will subsequently be transferred to the 200 Area ISA for storage until transfer off-site.

2.2.3.2 NRF TRIGA SNF. TRIGA SNF previously stored at the 308 Building annex was loaded into six NRF TRIGA ${ }^{\circ}$ Casks and transferred to the 400 Area ISA for storage in December 1995. TRIGAO Fuel Follower Control Rods were shipped at the same time and are being stored in two DOT 6M containers. The NRF TRIGA Casks and DOT 6M containers are stored in a vault module at the 400 Area ISA.

The NRF TRIGA Casks were designed with the intention of securing a DOE COC to enable shipment of the casks to INEL without repackaging. The DOT 6M casks are specification packages, and can be used for offsite shipment. The concrete vault will provide enhanced shielding during storage to meet the 400 Area ISA fence line maximum dose rate requirement of $0.5 \mathrm{mrem} / \mathrm{hr}$.

The NRF TRIGA casks, DOT 6M containers and vault will be transferred to the 200 Area ISA, consistent with the FFTF SNF transfers.

2.2.3.3 324/325/327 Building SNF. The two BWR assemblies and five PWR assemblies and miscellaneous pins and pieces stored primarily in the 324 Radiochemical Engineering (RE) Cells will be encapsulated and transferred to dry storage casks. Encapsulation is required because the cladding on the fuel cannot be verified to be intact and will be contaminated with cesium and strontium from a melter experiment upset condition. LWR SNF pins and pieces from the 325 and 327 Building hot cells will be transferred to the 324 Building RE Cells for decontamination and inclusion in the encapsulation. The fuel will be transferred to storage casks in the RE Cells' Air Lock and shipped to the 400 Area ISA for storage.

Casks are currently being procured that will be qualified for both on-site shipping and storage of the LWR SNF. The casks will be shipped to the 400 Area ISA for storage. The casks will later be relocated to the 200 Area ISA consistent with the FFTF SNF.

FFTF pins and pieces remaining at the 327 building will be returned to FFTF for disposition with the remainder of the FFTF SNF.

2.2.3.4 T Plant SNF. The 72 Shippingport PWR Core 2 assemblies stored at $T$ Plant will be retrieved, placed into canisters similar to the $K$ Basins SNF MCOS, dried, and transferred to the CSB for storage within the CSB vault.

2.2.3.5 PFP SNF. Three dissimilar fuel types are or will be stored at PFP: LAMPRE SNF, FFTF SNF, and University of Washington High-Enriched Uranium SNF. Because of physical differences, the storage systems for each of these SNF types will vary. The planning basis assumes that these SNF inventories will remain at PFP until transport for final disposition. 
Currentiy, the LAMPRE SNF is packaged in three EBR-II casks, which have primarily been used as on-site transportation casks. The SNF was initially managed as Remote-Handled Transuranic material and has only recently been relocated to the protected area at PFP. The three casks are stored inside a concrete vault to provide an additional security barrier and supplement the casks' lead shielding. A review of the cask for continued dry storage will be completed. The LAMPRE SNF will be repackaged prior to transport off-site for final disposition. The repackaging would occur at the CSB.

A small amount of highly enriched uranium fuel from the University of Washington is stored in a 55 gallon drum inside the 2736-ZB Building, also located in the protected area. The planning basis for this material is to repackage the material at the same time as the LAMPRE SNF. The University of Washington material is not likely to continue to be classified as SNF, based on recent discussions with the office of Spent Fuel Management. Therefore, the planning basis will likely be modified after formal reclassification is completed and the material dispositioned per requirements for highly enriched uranium.

The ISC's containing FFTF SNF designated for storage at PFP will be transported to an outdoor location inside PFP's protected area for storage on a precast concrete pad. This transfer is expected to take place by November 1998, but may be sooner depending on the staging of fuel for cleaning in the FFTF IEM Cell and the completion and approval of the onsite Safety Analysis Report for Packaging.

2.2.3.6 Burial Ground SNF. The thirteen drums of Oregon State University (OSU) TRIGA SNF are buried under four feet of soil in Trench 7 of the 218-W4C Burial Facility of the 200 West Area LLBG in TRIGA ${ }^{\oplus}$ Standard Fuel Element Storage Drums. Each drum contains ejther six or seven TRIGA elements for a total of 90 .

The SNF Project planning basis for management of the OSU TRIGA ${ }^{\otimes}$ SNF at the LLBG entails receipt and repackaging of the SNF at the CSB into NRF TRIGA Casks. The SNF would be exhumed simultaneous with solid waste retrieval. The casks will be staged at the 200 Area ISA until shipment off-site for final disposition.

\subsubsection{Schedule Objectives}

Schedule objectives to achieve safe interim storage of other Hanford Site SNF include removal of SNF from the following existing storage facilities to support the Hanford Site cleanup mission:

- Fast Flux Test Facility. Complete activities to offload FFTF fuel currently stored in sodium to dry storage casks by October 1998 to enable facility deactivation.

324/325/327 Buildings. Complete packaging and transfer of 324 Building B Cell SNF to storage casks by April 1997. Complete removal of remaining SNF inventories currently in the buildings by September 1999. 
- T Plant. Complete activities to remove SNF from T Plant by January 2001 to support the T Plant mission.

Additional schedules are identified in the October 1994 document, $P$ lan of Action to Resolve Spent Nuclear Fuel Vulnerabilities (Phase III) (DOE 1994a).

\subsubsection{Assumptions}

The scope identified in the Hanford SISMP for other Hanford SNF inventories are based on several key assumptions:

- Budget and manpower resources will be available in support of critical path activities.

- Current onsite transportation requirements will not change.

- RCRA permitting and NRC licensing (or NRC review) will not be required for new storage systems for other Hanford Site SNF.

- Current safeguards and security requirements identified in DOE Order 5333.2 will not change.

- Interim storage will be implemented consistent with the DOE-Owned Spent Nuclear Fuel Program's Interim Storage Plan (DOE 1995d).

\subsubsection{Issues and Problems}

Critical issues that must be resolved to identify or implement actions at the Hanford Site, and items that could limit schedule performance, include the following:

- Onsite transportation requirements must be maintained to enable onsite transport of SNF within schedule objectives. Offsite transportation capabilities must be developed to implement shipments off-site.

- Adequate funding levels and funding stability for SNF management must be established.

\subsubsection{Alternatives}

A formal systems engineering process is being used to establish and maintain a technical baseline for SNF management as described in Section 2.1.6. The systems engineering process scope includes other Hanford Site SNF inventories. Alternatives will be evaluated, when needed, using the systems engineering process.

Alternatives that are being evaluated, and in some cases have been dismissed, for other Hanford Site SNF include:

- Locating the SNF on a common storage pad in the 200 Area or 400 Area; 
- Utilizing the CSB for storage of other SNF;

- Transfer of commercial LWR SNF off-site for leased storage at an NRC licensed commercial SNF storage facility.

- Repackaging and staging SNF storage within the current storage facilities until transfer off-site for final disposition.

As a planning basis, the plan assumes storage of most of the FFTF SNF, the NRF TRIGA SNF, and the 324/325/327 Building SNF at the 400 Area ISA and subsequent relocation to the 200 Area ISA prior to shipment off-site. To satisfy

physical security requirements, the FFTF SNF which will be Category I prior to 2030 and the PFP SNF are planned for continued storage at PFP unti1 transfer off-site for final disposition.

Current planned actions and potential alternatives will be evaluated based on requirements established in the Hanford Site SNF Project Technical Baseline. Current planned actions will be supported, modified, or alternative approaches implemented based on the results of the evaluation. Transport and storage logistics for potential off-site shipments will be considered in conjunction with the DOE-Owned SNF Program's Interim Storage Plan.

\subsubsection{Technology Development}

Technology development will be required to support ultimate disposition of other Hanford Site SNF. However, readily available commercial technologies are sufficient to achieve safe interim storage of most of this SNF. Technology development will be limited primarily to qualifying the defense production reactor SNF at the $K$ Basins, as described in Section 2.1.8, for dry storage. Detailed technology development needs will be finalized through the systems engineering process. Technology development activities will be integrated with other DOE complex development activities through the DOE-Owned SNF Program's Technology Integration Technical Working Group and documented in the DOE Spent Nuclear Fuel Technology Integration Plan (DOE 1994b).

\subsection{RESOURCES}

Funding will be required to support expense-related activities and acquisition of four major systems related to the $\mathrm{K}$ Basins path forward. Actions to implement interim storage of other Hanford Site SNF inventories are not within the scope of DNFSB Recommendation 94-1 and, therefore, the associated costs are not identified in the SISMP.

Funding requirements to meet DNFSB Recommendation 94-1 IPP commitments for the $K$ Basins SNF are shown in Table 2-2. The total project costs, including continued $K$ Basins operations and maintenance, are also identified for reference purposes. 


\subsection{WORK PLAN}

Cost and technical baselines for the activities defined in the Hanford SISMP will be monitored on a monthly basis, and variance reports will be submitted to RL by the Spent Nuclear Fuel Project on the tenth working day of each month. The variance report will cover any variation between the baseline and actual schedule for DNFSB Recommendation 94-1 commitments or actions that affect those commitments. Explanation of the variance and plans for necessary corrective action will be provided. The technical baseline is subject to formal change control.

The baseline schedule is provided in Volume 2 of the SISMP. DNFSB Recommendation 94-1 commitments are identified.

\subsection{STAKEHOLDER INYOLVEMENT}

Hanford Site stakeholders are involved in decisions related to Hanford Site SNF management through three separate, but related, venues:

- The Office of Spent Fuel Management's stakeholder involvement program, which deals primarily with higher-level SNF management policy issues;

- NEPA review public involvement activities, particularly those that support Hanford site-specific SNF management, but also public involvement meetings for the SNF and INEL EIS;

- The Hanford Site SNF Project's site-specific stakeholder involvement program, which has focused significantly on the $K$ Basins path forward decision process.

The major Hanford Site stakeholders include: three major tribal governments (the Yakama Indian Nation, the Nez Perce Tribe, and the Confederated Tribes of the Umatilla Indian Reservation); the Hanford Advisory Board, which is primarily comprised of representatives from key Northwest public interest groups; and Hanford Site regulators, notably the State of Washington Department of Ecology and the U.S. Environmental Protection Agency. During the $K$ Basins fuel removal path forward decision process, input was requested from several stakeholder organizations, including the three major tribal governments and the Hanford Advisory Board's Major Safety and Waste Management Issues Working Group. Stakeholder feedback on subsequent refinements to the path forward decision has been and will continue to be requested on a routine basis. 


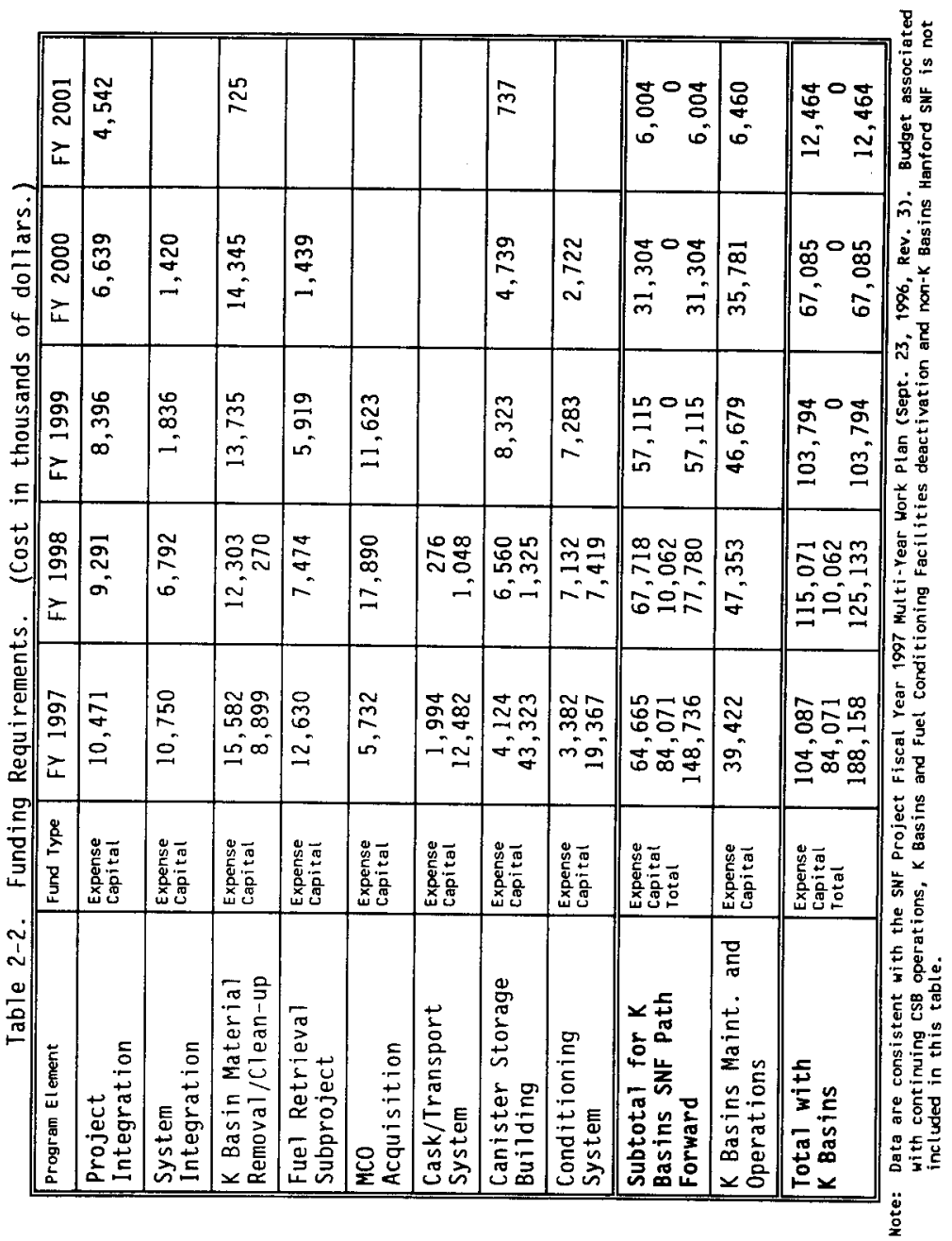




\subsection{PLUTONIUM-BEARING MATERIALS}

This portion of the Hanford SISMP covers the stabilization, repackaging, and storage or disposal of plutonium-bearing material in inventory at facilities currently operated by the Westinghouse Hanford Company as well as those nonwaste and plutonium-bearing materials arising from terminal cleanout of Hanford Site facilities. The scope of this SISMP also includes $1.8 \mathrm{~kg}$ of plutonium-bearing material shipped to PFP from Pacific Northwest National Laboratories (PNNL) and $1.2 \mathrm{~kg}$ of material shipped to PFP from Mound. The work responds to safety concerns identified in Defense Nuclear Facilities Safety Board Recommendation 94-1, dated May 26, 1994. This SISMP also includes specific corrective actions identified in the Plutonium Vulnerability Management Plan (DOE 1995c).

At Hanford's Plutonium Finishing Plant (PFP), the DNFSB was concerned that significant quantities of plutonium existed in unstable oxide and other chemical forms unsuited for long-term storage. Recommendation 94-1 calls for DOE to stabilize and repackage those unstable materials in its inventory. Per the DOE Recommendation 94-l Implementation Plan, the facility is committed to stabilize materials at urgent risk by May 1997 and all remaining at-risk materials by May 2002. Metals and oxides greater than 50 weight percent (wt\%) Pu will be stabilized and packaged to the long-term storage standard contained in DOE-STD-3013.

While PFP's inventory of plutonium-bearing materials awaits stabilization and repackaging to long-term storage standards, the DOE Criteria for Interim Storage of Plutonium-Bearing Materials provide guidance for the interim safe storage of plutonium-bearing solid materials for a period of five to twenty years. The SISMP lays out the strategy by which PFP will meet the requirements of the Recommendation 94-1 stabilization program.

PFP has the capacity to stabilize and store, or dispose of as transuranic waste, all of the materials in the current PFP inventory, as well as those materials resulting from Hanford's terminal cleanout operations in future, if the equipment and systems called for in this plan are installed. However, PFP is programmatically constrained by the PFP Environmental Impact Statement (EIS) in its ability to separate plutonium from residues.

Processing enhancements needed to complete the Hanford Site stabilization program in response to Recommendation $94-1$ by May 2002 have been identified; these enhancements are described in more detail in this SISMP. The enhanced processing capability would be available to process material from other U.S. Department of Energy sites and/or to meet other Hanford Site requirements, if necessary, after completion of this program.

Schedules and funding profiles are also included in this SISMP. A total of $\$ 124$ million above routine facility surveillance and maintenance costs over 7 years is required to execute this plan.

Three site specific concerns have been identified:

- Radiological dose to personnel associated with the work

- NEPA and RCRA compliance and permitting constraints 
WHC-EP-0853 Rev. 3

- Integration of International Atomic Energy Agency (IAEA) safeguards with stabilization activities and long-term storage

\subsection{INTRODUCTION}

\subsubsection{Scope}

The SISMP encompasses plutonium-bearing materials currently held by WHC at the Hanford Site, and includes the items currently and previously held by PNNL as well as the three items received from Mound $(1.2 \mathrm{~kg})$. PNNL is currently preparing $1.2 \mathrm{kgs}$ of its inventory for grouting and disposal by September 1996, per the Hanford Waste Acceptance Criteria. The remaining PNNL material, $1.8 \mathrm{kgs}$ has been packaged and shipped to PFP for stabilization and storage. Table 3-1 shows that the WHC material, including the PNNL material (1.8 $\mathrm{kgs}$ ), totals approximately 4 metric tons, net weight, of plutonium distributed among approximately 8,038 items. $100 \%$ of the plutonium at PFP has been declared excess to national security needs. Approximately one ton of the inventory is currently under IAEA safeguards. For stabilization considerations, plutoniumbearing material has been grouped into three categories:

- Solutions

- Residues and oxides (<50 wt\% Pu)

- Metals and oxides (>50 wt\% Pu)

The items constitute a wide range of chemical and physical properties, including metals, pure (>85\%) plutonium oxides, high grade $(50-85 \%)$ oxides, solutions, mixed plutonium/uranium oxides, fuel pins and assemblies, process holdup, and other residues (sand, slag, and crucible, ash, polycubes, etc.) Table 3-1 lists the inventory of these plutonium-bearing materials in greater $\operatorname{detail.~}$

Three main process paths have been planned for these materials as follows:

- Solutions are planned to undergo stabilization in the vertical calciner.

- Most residues and oxides of less than 50 wt\% Pu will be pretreated as necessary, cemented and sent to Waste Isolation Pilot Plant (WIPP) for disposal. Several residue trade studies are in progress to evaluate whether materials should be processed to meet DOE-STD-3013 or prepared for geologic disposal. Given the uncertainties which remain unresolved pending final recommendations from the trade studies, PFP has made some programmatic plans for these materials which are contained in the following sections of this SISMP.

- For metals and oxides of greater than 50 wt\% Pu, materials will be stabilized and repackaged to DOE-STD-3013 criteria. In 1998 Hanford is scheduled to receive from British Nuclear Fuels, Limited (BNFL) a Stabilization and Packaging System (SPS). The SPS is scheduled to be operational by 0ctober 1999 and should complete the stabilization and repackaging ahead of the May 2002 milestone. For metals and oxides containing impurities which render them incompatible with the SPS, 
stabilization will occur in the muffle furnaces followed by repackaging in the SPS.

Approximately three metric tons of plutonium is scheduled to undergo stabilization and repackaging in the SPS machine and/or the muffle furnaces, including the pure and high-grade oxides, stabilized solutions product, and metals. Programmatic decisions for the remainder of the inventory are discussed in the following sections, although decision factors for some materials such as residues for which trade studies are ongoing, and impacts of IAEA safeguards, have not yet been factored in. The recently released Record of Decision (ROD) issued for PFP Clean-out and Stabilization EIS supports completion of the actions described in this SISMP. Figure 3-1 displays the stabilization and storage material flow for the DNFSB 94-1 baseline plan. Figure 3-2 illustrates the PFP building layout and the location of processing equipment. Table 3-2 lists the milestones identified for DOE to complete the commitments outlined in the DNFSB Recommendation 94-1 Implementation Plan.

Necessary DOE-STD-3013 compliant storage capability for the stabilized and repackaged material is al so included in the SISMP. The storage of the FFTF unirradiated fuel assemblies is addressed in this plan but no actions are required. These assemblies are considered stable and suitable for 50-year storage as is. 
Table 3-1. Inventory of Plutonium-Bearing Materials.

\begin{tabular}{|c|c|c|}
\hline Material Type & No. of Items & $\mathrm{Pu}$ in Kgs \\
\hline \multicolumn{3}{|c|}{ Metals and 0xides addressed by DOE-STD- 3013} \\
\hline Metal & 352 & 736 \\
\hline Oxides > 50 wt\% $\mathrm{Pu}$ & 2627 & 1878 \\
\hline Mixed Oxides $<50$ wt $\% \mathrm{Pu}$ & 2297 & 323 \\
\hline Subtotal & 5276 & 2937 \\
\hline \multicolumn{3}{|c|}{ Materials to be converted to meet DOE-STD-3013 } \\
\hline Solutions & 446 & 335 \\
\hline Polycubes & 251 & 34 \\
\hline Subtotal & 697 & 369 \\
\hline \multicolumn{3}{|c|}{$\begin{array}{l}\text { Materials to be addressed by the Residue Policy, Trade Studies, \& Interim } \\
\text { Storage Criteria }\end{array}$} \\
\hline Oxide $<50$ wt $\% \mathrm{Pu}$ & 561 & 79 \\
\hline Ash & 545 & 80 \\
\hline Slag and Crucible & 266 & 43 \\
\hline Compounds & 28 & 4 \\
\hline Alloys & 125 & 34 \\
\hline Sources & 199 & 24 \\
\hline Process Holdup & $N / A$ & 72 \\
\hline Other/Miscellaneous & 28 & 1 \\
\hline Other Combustibles & 12 & 1 \\
\hline Subtotal & 1764 & 338 \\
\hline \multicolumn{3}{|c|}{ Materials stored in exception to either standard } \\
\hline Fuel Pin Assemblies & 168 & 714 \\
\hline Grand Total & 7905 & 4358 \\
\hline
\end{tabular}


Figure 3-1. Material Flow for DNFSB 94-1 Baseline Plan.

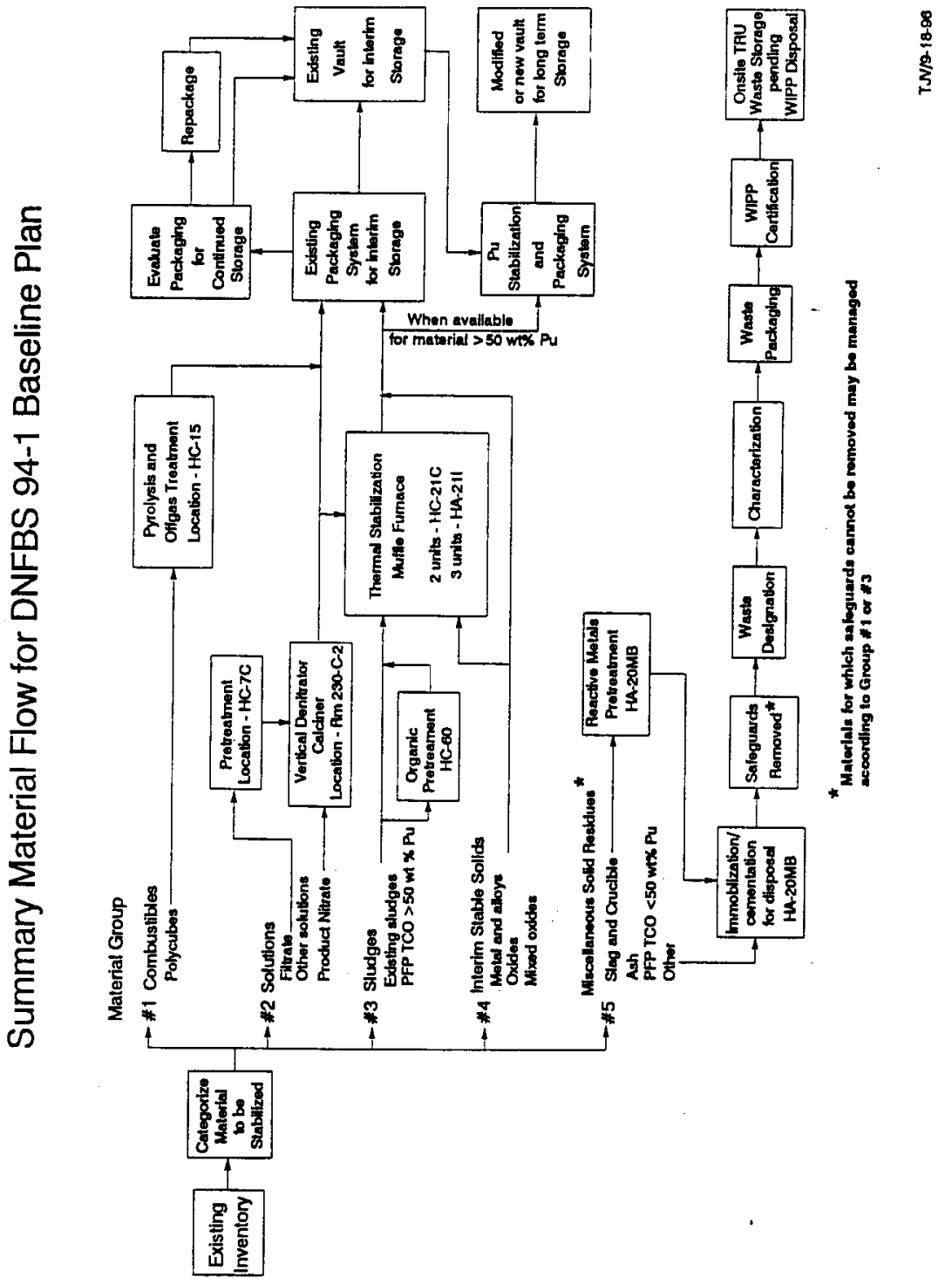


Figure 3-2. PFP Building Layout - Location of Process Areas.

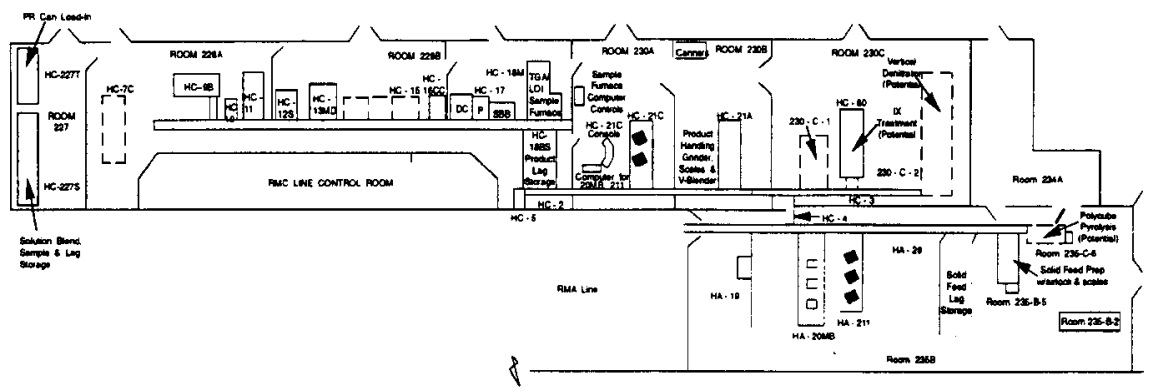

$C$ Line and $A$ Line Process Areas

Location of Thermal Stabilization Areas
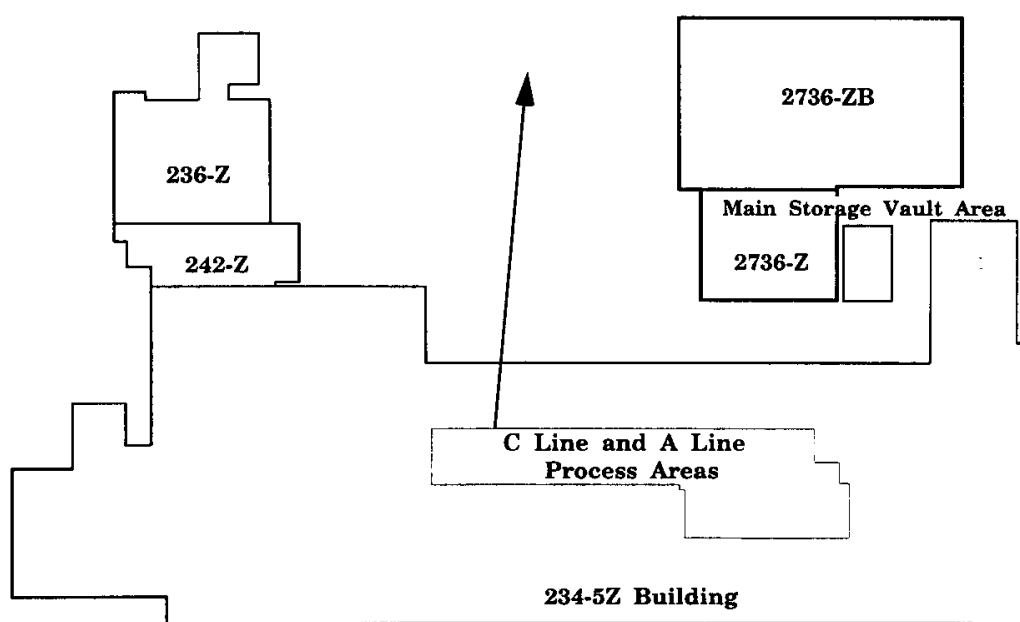

234-5Z Building 
Table 3-2. Milestone Summary.

\begin{tabular}{|c|c|c|}
\hline Activity & Milestone & Comments \\
\hline $\begin{array}{l}\text { Issue Material } \\
\text { Characterization Plan }\end{array}$ & March 1995 & Completed March 1995 \\
\hline $\begin{array}{l}\text { Initiate and complete } \\
\text { transfer of PUREX solutions } \\
\text { to tank farms for disposal. }\end{array}$ & August 1995 & $\begin{array}{l}\text { IP-3.1-023 \& IP-3.1-024; } \\
\text { Completed Apri1 1995. }\end{array}$ \\
\hline $\begin{array}{l}\text { Start engineering studies of } \\
\text { a new repackaging line at } \\
\text { Hanford }\end{array}$ & September 1995 & $\begin{array}{l}\text { IP-3.2-028; Completed } \\
\text { September } 1995 \\
\text { The studies have been } \\
\text { replaced by the } \\
\text { consolidated procurement } \\
\text { effort. }\end{array}$ \\
\hline $\begin{array}{l}\text { Stabilize sludge residue } \\
\text { inventory. }\end{array}$ & September 1995 & $\begin{array}{l}\text { IP-3.3-031; Completed June } \\
\text { 1995. }\end{array}$ \\
\hline $\begin{array}{l}\text { Stabilize high-risk } \\
\text { solutions }\end{array}$ & September 1995 & $\begin{array}{l}\text { IP-3.1-015; } 220 \text { liters ( } 27 \\
\text { items) containing chlorides } \\
\text { and fluorides in PFP } \\
\text { Process Support Laboratory. } \\
\text { Completed September } 1995 \\
\end{array}$ \\
\hline $\begin{array}{l}\text { Verify venting of solution } \\
\text { containers }\end{array}$ & December 1995 & $\begin{array}{l}\text { IP-3.1-014; Completed May } \\
\text { 1995. }\end{array}$ \\
\hline $\begin{array}{l}\text { Stabilize high-risk } \\
\text { incinerator ash }\end{array}$ & March 1996 & $\begin{array}{l}\text { IP-3.3-032; } 46 \text { items of } \\
\text { reactive incinerator ash } \\
\text { Completed January } 1996 \\
\end{array}$ \\
\hline $\begin{array}{l}\text { Complete solution technology } \\
\text { development at PFP }\end{array}$ & March 1996 & $\begin{array}{l}\text { IP-3.1-021; completed Apri1 } \\
\text { 1996. }\end{array}$ \\
\hline $\begin{array}{l}\text { Feasibility of Calciner } \\
\text { Modification }\end{array}$ & March 1996 & $\begin{array}{l}\text { Impacts decision on use of } \\
\text { new vs. existing } \\
\text { development model; } \\
\text { completed March } 1996 . \\
\end{array}$ \\
\hline Issue Dose Evaluation Study & June 1996 & $\begin{array}{l}\text { Impacts design of process } \\
\text { systems; completed June } \\
1996\end{array}$ \\
\hline PFP EIS-ROD & June 1996 & $\begin{array}{l}\text { IP-3.1-016; completed June } \\
1996\end{array}$ \\
\hline $\begin{array}{l}\text { Begin processing solutions } \\
\text { at PFP }\end{array}$ & June 1997 & IP-3.1-022 \\
\hline $\begin{array}{l}\text { Complete detailed design, } \\
\text { equipment procurement, and } \\
\text { installation of a new } \\
\text { repackaging system at } \\
\text { Hanford }\end{array}$ & December 1998 & IP-3.2-029 \\
\hline
\end{tabular}


WHC-EP-0853 Rev. 3

\begin{tabular}{|c|c|c|}
\hline Activity & Milestone & Comments \\
\hline $\begin{array}{l}\text { Complete stabilizing } \\
\text { remaining solutions }\end{array}$ & January 1999 & $\begin{array}{l}\text { IP-3.1-017; } 4,800 \text { liters } \\
\text { total inventory. } \\
\text { Approximately } 4,300 \text { liters } \\
\text { remain to be stabilized. }\end{array}$ \\
\hline $\begin{array}{l}\text { Start restabilizing high } \\
\text { assay oxides at PFP }\end{array}$ & Ju7y 1999 & IP-3.2.033 \\
\hline $\begin{array}{l}\text { Begin stabilization of } \\
\text { polycubes. }\end{array}$ & July 1999 & IP-3.3-028 \\
\hline $\begin{array}{l}\text { Train staff, prepare } \\
\text { procedures, perform } \\
\text { operational readiness } \\
\text { testing (prior to commencing } \\
\text { operations) }\end{array}$ & September 1999 & IP-3.2-030 \\
\hline $\begin{array}{l}\text { Commence repackaging } \\
\text { operations at Hanford }\end{array}$ & October 1999 & $I P-3.2-031$ \\
\hline $\begin{array}{l}\text { Complete stabilize reactive } \\
\text { solid residues }\end{array}$ & January 2000 & $\begin{array}{l}\text { IP-3.3-026; Sand, slag, \& } \\
\text { crucible, and poorly } \\
\text { characterized items }\end{array}$ \\
\hline $\begin{array}{l}\text { Complete metal repackaging } \\
\text { at Hanford. }\end{array}$ & September 2000 & IP-3.2-032 \\
\hline $\begin{array}{l}\text { Complete stabilization of } \\
\text { polycubes. }\end{array}$ & January 2001 & IP-3.3-029 \\
\hline $\begin{array}{l}\text { Complete stabilize remaining } \\
\text { residues }\end{array}$ & January 2002 & IP-3.3-027 \\
\hline $\begin{array}{l}\text { Repackage } 1.2 \mathrm{~kg} \text { Pu metals } \\
\text { and oxides received from } \\
\text { Mound to meet the metal and } \\
\text { oxide standard. }\end{array}$ & May 2002 & $1 P-3.2-101 C$ \\
\hline $\begin{array}{l}\text { Complete thermally stabilize } \\
\text { and repackage all plutonium } \\
\text { oxide to meet the metal and } \\
\text { oxide storage standard. }\end{array}$ & May 2002 & IP-3.2-018; IP-3.2-034 \\
\hline $\begin{array}{l}\text { Complete stabilizing and } \\
\text { packaging all remaining } \\
\text { residues, including alloys. }\end{array}$ & May 2002 & IP-3.3-033 \\
\hline
\end{tabular}




\subsection{SOLUTIONS}

\subsubsection{Scope}

The scope of this portion of the Hanford SISMP is the initial inventory of plutonium-bearing solutions at PFP. The inventory at PFP contained approximately 4,804 liters of solution consisting of: 4,514 liters of nitrate solutions; 270 liters of chloride and miscellaneous solutions; and 20 liters of organic solutions. These solutions are in 10-1iter containers in storage in the 234-5Z Building. The chloride and fluoride solutions were considered to be the greatest risk to container integrity based on their reactive nature and resulting container corrosion, and therefore received early attention. Stabilization of solutions during developmental and preproduction testing have reduced the solution inventory to approximately 4,300 liters.

\subsubsection{Remediation Objectives and Endstate}

The objective is to transform the current inventory of solutions to a stable form suitable for 50-year storage. When this path is not appropriate to the material form, the objective is to discard those solutions as TRU waste to the Hanford Tank Farms. The product form for the stabilized solutions will be plutonium oxide fired to the temperature necessary to meet the DOE standard for 50-year storage. The inventory of stabilized solutions will be $>50$ wt\% plutonium requiring that the stabilized material be packaged in accordance with DOE-STD-3013.

The 20 liters of organic solution, as well as any other solutions that are not compatible with the planned processing capability without extensive

pretreatment, will be evaluated for immobilization and discarded as TRU waste. Alternately, the organic solutions may be compatible for stabilization in the pyrolysis furnace system as discussed in the residues section.

\subsubsection{Concept of Operations}

Plutonium solutions at PFP consist of nitrate, flush, and filtrate and are stored in 10 liter containers awaiting transformation to oxide or transfer to the Hanford Tank Farms. Transformation priority will be given to the nitrate solutions. The nitrate solution containers will be loaded into process storage tanks in Room 227 , then vacuum transferred to the vertical denitration calciner glovebox to be stabilized into oxide and heated to $1000^{\circ} \mathrm{C}$. The product oxide is then removed and canned to be compliant with DOE interim storage criteria until the SPS is available for repackaging to meet DOE-STD3013. The path to stabilization for the flush and filtrate solutions mirrors the nitrate solution path with an additional ion exchange pre-treatment step to purify the low concentration plutonium solutions for effective operation of the calcination process. Waste solutions generated by the pretreatment process are transferred to Hanford waste tanks for disposal.

\subsubsection{Remediation Process}

Hanford Site laboratory personnel have completed developmental testing of equipment and processes to determine the appropriate method for stabilizing the solutions at PFP. Direct denitration calcination using a continuously 
operating vertical calciner was selected as the stabilization method for solutions. Solutions will be stabilized in the calciner to meet DOE-STD-3013.

Pretreatment of a portion of the solutions at Hanford will be done by an ion exchange process. Laboratory personnel will conduct pre-production testing of the ion exchange pretreatment process and proof tests of the prototype vertical calciner improvements.

All liquid waste generated from the solution stabilization process will be routed through existing systems and disposed of to the Hanford Site waste tanks in accordance with the current waste tank acceptance criteria. The expected volume of waste is minimal and can easily be accommodated by the Hanford waste tanks.

3.2.3.1 Preparation. The preparation phase for solution stabilization at PFP addresses near-term actions to mitigate risks identified with the continued storage of solutions in 10-1iter containers. Inspection of the solutions stored in 10-7jter containers was completed in May 1995. This ensured that all containers were properly vented to preclude the potential for pressurization caused by the generation of hydrogen gas. This inspection activity completed the actions necessary to fulfill the requirements of Milestone IP-3.1-014, "All bottles of plutonium solutions at Hanford inspected to ensure proper venting."

Another near-term risk mitigation activity was the stabilization of roughiy 270 liters of chloride and fluoride solutions by precipitation of the plutonium with magnesium oxide followed by calcination at $1000^{\circ} \mathrm{C}$ in a muffle furnace. This action was part of the solution stabilization development program conducted in the Plutonium Process Support Laboratory (PPSL). The resultant oxide material was packaged to the interim safe storage criteria. The stabilization, packaging, and storage of chloride and fluoride solutions completed the actions necessary to fulfill the requirement of Milestone "IP3.1-015; 220 liters of chloride solutions at Hanford stabilized" in September 1995.

Direct denitration (vertical calciner) was selected as the system to stabilize plutonium solutions for purposes of schedule formulation. The outcome of the developmental test program was a decision report in April 1996 documenting the results of the testing. Completion of this developmental program and the issuance of the test report completed the requirements of Milestone "IP-3.1021; Complete solution technology development at Hanford Plutonium Finishing Plant (PFP)."

The issuance of the PFP EIS Record of Decision (ROD) in June 1996 allows implementation of the stabilization processes identified in this SISMP. Issuance of the PFP ROD in June 1996 has fulfilled the requirement of Milestone "IP-3.1-016; ROD issued for PFP Clean-out and Stabilization EIS." Completion of these milestones was documented by letter to RL.

The Functional Design Criteria (FDC) and Conceptual Design Requirements (CDR), including detailed cost and schedule information for Project $\mathrm{C}-226$, Vertical Calciner, have been issued. Advanced conceptual design activities were completed in September 1996. Definitive design authorization has been 
provided by DOE and this activity is underway. The project schedule included as part of the CDR indicates a potential two-month startup date variance with the milestone. The solution milestone completion date of January 1999 remains unchanged.

Safety analysis for Project $\mathrm{C}-226$ will ensure safe operation and provide the proper safety documentation to comply with applicable DOE Orders (DOE 5480.22 and DOE 5480.23). Compliance with the Orders will ensure the protection of the environment and the employees; members of the general public are not subject to undue risk. Fabrication, procurement, and site preparation will start concurrently. Then the installation of the solution stabilization equipment and development of procedures begin. Once procedures are developed and approved and equipment installed, operators are trained and preproduction testing of the equipment occurs.

Readiness assessment scoping will be done by the contractor to establish the breadth and depth of the assessment. Prior to startup, a readiness assessment will be conducted by the contractor for the solution stabilization process in accordance with established contractor readiness process procedures that ensure compliance with DOE Order 5480.31. This readiness process shall focus on the adequacy of hardware, personnel, and the administrative process necessary to support and maintain the safe operation of the stabilization activity. After the readiness process is completed and readiness is verified, written authorization to proceed with the solution stabilization program work will be provided to plant management by RL. Completion of the readiness process ends the preparation activities required prior to startup of the solution stabilization process. Completion of the readiness process also responds to DOE's policy that facilities will be started or restarted in accordance with DOE Order 5480.31 .

3.2.3.2 Production. Startup of solution stabilization is scheduled to be initiated in September 1997. Startup fulfills the requirement of Milestone "IP-3.1-022; Begin processing solutions at PFP." Solutions will be processed through the vertical calciner with a projected throughput of 5407 iters of feed per month. This figure is based on the assumptions identified in Section 3.2 .5 below. At this rate the inventory of solutions is expected to be processed within ten months to transform the current inventory of solutions to a stable form to meet DOE-STD-3013.

Solution processing will be completed in June 1998, ahead of the milestone schedule. Completion of solution processing fulfilis the requirement of Milestone "IP-3.1-017; Stabilization of 4,800 liters at PFP completed." Completion of these milestones will be documented by letter to RL.

\subsubsection{Schedule Objectives}

Schedule details for solution stabilization are shown in Appendix $B$ of Volume 2 of this report.

- Developmental testing on the vertical calciner began in June 1995 and was completed in April 1996. 
- Procurement and installation of the selected system will begin upon project authorization. Initial startup of the new system is anticipated in September 1997 with the projected throughput of 540 liters of feed per month reached by October 1997.

- Stabilization of the solutions is projected to be completed in June 1998, well before the date required by the milestone.

- Denitration pretreatment system will be installed by September 1997 .

\subsubsection{Assumptions}

The following assumptions were considered in the development of the solution portion of the Hanford SISMP:

1. Dose rates associated with solution stabilization will be manageable given the WHC/DOE administrative 1 imit of 1,500 mrem exposure per year. A dose evaluation, discussed below in Section 3.6, was completed to confirm this assumption.

2. Vault modifications will be required to store the DOE-STD-3013 container. Facility modifications needed for packaging and storage of plutonium containers to the DOE Standard are scheduled to be operational with FY 1998 line jtem.

3. Stabilized high-assay ( $>50 \mathrm{wt} \% \mathrm{Pu}$ ) solution material produced by the calciner will be interim stored, then retrieved from storage when the SPS is available and repackaged to DOE-STD-3013 without additional stabilization.

4. Operations will be on a 24-hour-per-day, 5-day-per-week basis, and funding will be provided to support Project $\mathrm{C}-226$ by August 1996 .

- Throughput for the vertical calciner will be 540 liters per month following three months of system operation.

- Startup of the ion exchange pretreatment process may lag the startup of the direct denitration vertical calciner to allow earlier startup of the solution stabilization process for solutions which do not require pretreatment.

\subsubsection{Issues and Problems}

The following issues and problems have been identified which could affect the ability of the solution stabilization program to meet its objectives:

1. The disposal of selected low-assay plutonium solutions may be delayed by the need to obtain approval authority for domestic safeguards termination on items designated as waste. PFP is coordinating with RL to develop and/or obtain the appropriate criteria for safeguards termination. Alternatives treatment options are described in alternatives section 3.2 .7 item 2 . 
2. The draft DOE-STD-3013-96 requires a two-hour residence at $950^{\circ} \mathrm{C}$ for material in the vertical calciner. Currently the calciner is planned to hold materials for an average four hour residence at $1000^{\circ} \mathrm{C}$ in accordance with the existing DOE-STD-3013-94. Current test data indicates that the calciner product meets all loss-on-ignition (LOI) requirements.

3. The vertical calciner is not a suitable process to stabilize organic solutions. Alternative methods are described in the next section, 3.2.7 item 2.

\subsubsection{Alternatives/Impacts}

1. To address the pending revision to the long term storage standard, DOESTD-3013-96, oxides resulting from the direct denitration calcination process may need to be restabilized utilizing the SPS.

2. Two alternative methods to stabilize organic solutions are planned: 1) Immobilization of the solution in a solid absorbent and packaging the material as TRU solid waste. Issues of discarding plutonium-bearing material as TRU waste are expected to be resolved with the approval of an engineering evaluation of the economics of storage versus disposal. Current U.S. Department of Transportation regulations (49 CFR 172 and 173) make shipment of solutions to another site nonviable; and 2) Stabilization of the solutions in small batches using a thermal stabilization method such as a pyrolysis furnace (Project $\mathrm{C}-227$ ) described further in the residues section. This alternative would require a safety appraisal to establish the safe batch size.

\subsubsection{Technology Development}

Work in the PPSL completed in April 1996 has developed and demonstrated the technology to be used at PFP for stabilization of aqueous plutonium solutions. Pre-production testing by PPSL continues to support the final design and operating parameters of the vertical calciner.

\subsection{RESIDUES AND OXIDES ( $<50 \mathrm{wt} \% \mathrm{Pu}$ )}

\subsubsection{Scope}

The scope of this portion of the Hanford SISMP addresses plutonium residues and wet solids currently in inventory at PFP. The residue inventory at PFP includes the following material types:

- Low-organic sludge holdup: The backlog inventory of 236 items of 1 loworganic sludge residues at the PFP has been stabilized in the muffle furnaces at $1000{ }^{\circ} \mathrm{C}$ for one hour and $0.5 \mathrm{wt} \%$ loss on ignition (LOI), thereby meeting DOE's interim storage criteria. Low-organic sludge residues contain less than 2 wt\% organics. This activity completed the actions necessary to fulfill the requirements of Milestone 3.3-031 "Stabilize existing inventory of sludge (low organic residues) in muffie 
furnaces", June 1995. Completion of this milestone was documented by letter to RL.

- High-organic sludge holdup: Sludges containing greater than $2 \mathrm{wt} \%$ organics may be generated during terminal cleanout activities. Much of the material arising from terminal cleanout work at PFP will either be immobilized and discarded as waste, or may have sufficient plutonium content ( $>50 \mathrm{wt} \% \mathrm{Pu}$ ) to warrant thermal stabilization. Because of the potential for generation of flammable concentrations of butene from the decomposition of organics, material characterization will determine whether selected high-organic sludges will require hydrolys is for organic destruction prior to thermal stabilization.

- Sand, slag, and crucible, ash, oxide residues, compounds, and other miscellaneous dry residues: The inventory of plutonium-bearing residues includes sand, slag, and crucible (SS\&C), incinerator ash, and other miscellaneous dry residues from prior process operations, some of which contain fluorides, calcium metal powder and pellets, and iodine. The inventory of these residues includes approximately 1,428 items with a bulk weight of about $3,765 \mathrm{~kg}$. These items are currently stored in the $234-5 Z, 2736-Z$, and $2736-Z B$ Building storage vaults.

PFP's inventory of reactive incinerator ash (46 items contained in 52 cans) has been stabilized to $1000{ }^{\circ} \mathrm{C}$ for three to four hours and $1 \%$ LOI at $450{ }^{\circ} \mathrm{C}$ in accordance with current Hanford vault storage

specifications. This material was then packaged to the DOE interim safe storage criteria. The stabilization and storage of the reactive incinerator ash completed the actions necessary to fulfill the requirement of Milestone "IP-3.3-032; Stabilize 46 cans of selected ash from RF in the muffle furnaces." Milestone IP-3.3-032 was completed in January 1996. Completion of this milestone was documented by letter to DOE.

- Polycubes and 0ther Combustible Solids: The inventory of combustible solids includes 251 items containing approximately 1,800 polycubes of various sizes with a total of approximately $34 \mathrm{~kg}$ plutonium. The miscellaneous combustible solids are contained in 12 items of $8 \mathrm{~kg}$ bulk weight. These items are not an imminent hazard because they are not susceptible to spontaneous combustion, and they are packaged and stored to allow proper venting. Polycubes will be stabilized and stored in accordance with DOE-STD-3013 criteria. Some combustibles may require pyrolysis, thermal stabilization, packaging and storage. Other combustibies will be evaluated for discard in accordance with the WIPP Waste Acceptance Criteria.

- Alloys, Sources, and Other Residues: All other solid, plutonium-bearing residues also contain less than 50 wt\% plutonium. This inventory includes about 2,200 items totaling about $3,000 \mathrm{~kg}$ bulk weight of oxides which meet DOE interim safe storage criteria based on previous thermal treatment. This material is currently stored in the $2736-Z$ and $2736-Z B$ Vaults. Programmatic decisions are pending to determine long term storage or discard to WIPP of these residues. 
- Unirradiated fuel pins and assemblies: The FFTF unirradiated fuel pins and assemblies are in storage at PFP and FFTF. They are considered acceptable in their current state for long-term storage; therefore, no further near-term actions are envisioned for these materials.

- Mixed plutonium/uranium oxides (MOX): MOX pellets, powders, and scrap containing greater than 50 wt\% plutonium plus uranium will be addressed in Section 3.4, Metals and 0xides. MoX residues containing less than 50 wt\% Pu will be evaluated for discard to WIPP.

Plutonium residues and sludges left over from operation of the Plutonium Reclamation Facility (PRF), generated from cleanout of process gloveboxes and equipment, or recovered during the terminal cleanout of process support equipment and ductwork will also be addressed. As cleanup and deactivation activities continue, up to $72 \mathrm{~kg}$ of plutonium may be recovered from PFP.

\subsubsection{Remediation Objectives and Endstate}

The objective of remediation activities is to transform residues to the following endstates:

- Low-organic sludges: Will be immobilized and discarded through the cementation process to WIPP.

- High-organic sludges: Will be immobilized and discarded as TRU waste to WIPP, or if materials contain sufficient plutonium content ( $>50 \mathrm{wt} \% \mathrm{Pu}$ ), processed to a stable plutonium oxide form which meets DOE-STD-3013.

- Sand, slag, and crucible, ash, and other miscellaneous dry residues: Will be immobilized through the cementation process and discarded as TRU waste to WIPP.

- Polycubes and Other Combustible Solids: Polycubes will be packaged, stabilized and stored in accordance with DOE-STD-3013 criteria. 0ther combustibles will either undergo pyrolysis with thermal stabilization and storage, or will be evaluated for discard to WIPP.

- Alloys, Sources, and Other Residues: Programmatic decisions are pending to determine long term storage or immobilization and discard as TRU waste per WIPP/WAC.

- Unirradiated fuel pins and assemblies: The FFTF unirradiated fuel pins and assemblies are considered acceptable in their current state for long-term storage; therefore, no further near-term actions are envisioned for these materials.

- Mixed plutonium/uranium oxides (MOX): MOX pellets, powders, and scrap containing greater than 50 wt\% plutonium plus uranium will be addressed in Section 3.4, Metals and 0xides. MoX residues containing less than 50 wt\% plutonium plus uranium witl be evaluated for discard as TRU waste to WIPP per WAC. 
The trade studies underway for ash and SS\&C will determine whether other options are available and cost-effective. For those materials such as polycubes which will contain greater than 50 wt\% $\mathrm{Pu}$, material will be transformed to oxides during stabilization, then packaged to DOE-STD-3013 criteria for long-term storage.

\subsubsection{Concept of Operations}

For stabilization and repackaging purposes, PFP's residue inventory will follow one of four processing paths:

1) Polycubes will be thermally stabilized and stored to DOE-STD-3013 criteria.

2) Recovered terminal cleanout material such as low- and high-organic sludges will be cemented and prepared for discard to WIPP.

3) Vault-stored process residues which do not require thermal stabilization will be cemented and prepared for discard as TRU waste to WIPP.

4) Alloys will be repackaged; sources and MoX material containing less than 50 wt\% plutonium and uranium will be evaluated to determine the appropriate stabilization method, and if indicated will undergo thermal stabilization.

Some residues may remain in interim storage in the vaults until programmatic decisions on remediation are made.

The first stabilization path will be followed for polycubes. A pyrolysis stabilization system (Project $C-227$ ) will be installed in Room 228B. The polycubes will be transferred from storage and unpacked in a feed preparation glovebox in Room 230B. Then the polycubes will be transferred to the pyrolysis glovebox via conveyor for stabilization. The product will be oxides thermally stabilized in accordance with DOE-STD-3013. Since polycube stabilization will begin before the SPS is operational, the oxides will be packaged to the Hanford vault criteria and stored in the PFP vaults pending repackaging in the SPS to DOE-STD-3013 standard cans. Following repackaging, the resultant oxides will be suitable for long-term storage in the Hanford vaults.

The second stabilization path will apply to plutonium-bearing residues resulting from terminal cleanout such as low- and high-organic sludges. These materials will be consolidated for treatment, cementation and disposal to WIPP.

The third stabilization path will be utilized for vault-stored process residues including ash, sand, slag, and crucible, low-grade oxides, etc. These residues will be cemented and prepared for discard to WIPP. AII ash at PFP has been stabilized to interim storage criteria. Sand, slag, and crucible will be reacted with water and then cemented. Packaging of residues will be in accordance with WIPP requirements. 
The fourth stabilization path will be utilized for alloys, which will be repackaged in the SPS. Sources and MOX material containing less than 50 w $\%$ plutonium and uranium will be characterized and evaluated to determine the appropriate stabilization method, and if indicated will undergo thermal stabilization.

For further detail on stabilization processes, see Section 3.3.3, Remediation Processes.

\subsubsection{Remediation Processes}

Polvcube Stabilization: Polycubes will require treatment to decompose and separate the polystyrene from the plutonium oxide. The polycubes will be treated in a two-stage pyrolysis furnace to decompose and vaporize the polystyrene, burn off the residual carbon, and stabilize the residual plutonium oxide. The unit to be utilized for polycube stabilization will be located in Room 228B of the 234-5Z Building. Development of the pyrolys is system is being conducted at Los Alamos National Laboratory (LANL) with direction from Hanford. The development focuses on batch pyrolysis with offgas treatment. Three offgas treatment methods were considered: catalytic conversion, silent plasma discharge, and secondary combustion. The silent plasma discharge method was selected in July 1996 and will be provided by LANL with the polycube process unit.

Stabilization of Residues: The process for stabilization of MoX containing less than 50 wt\% plutonium plus uranium will be determined by PFP. High assay plutonium-bearing residues resulting from terminal cleanout activities will undergo thermal treatment to DOE-STD-3013 criteria. The process currently uses two muffle furnaces located in Room 230-A of the 234-5Z Building. Figure 3-2 shows the location of the existing and proposed process equipment. Furnace temperatures are regulated to first vaporize volatile material at low temperature $\left({ }^{\sim} 200^{\circ} \mathrm{C}\right)$ if organics are present and then to raise temperatures ultimately to $1000^{\circ} \mathrm{C}$ for stabilization to DOE interim criteria. After a two hour soak at the maximum temperature, the material is allowed to cool in a controlled environment. Items containing greater than $50 \mathrm{wt} \% \mathrm{Pu}$ are packaged to existing Hanford Site criteria, which means the material is packaged in a slip lid can, bagged out, and nested into two mechanically sealed food-pack cans.

For high-organic sludge residues slated to undergo thermal treatment, pretreatment prior to thermal stabilization will be required. The pretreatment process, hydrolysis, is partially installed in glovebox $\mathrm{HC}-60$ of Room 230-C in 234-5Z Building. Completion of installation, testing, and readiness assessment are required prior to startup of this equipment.

Preparation for Disposal: Vault-stored residues containing less than 50 wt\% Pu do not require thermal stabilization and thus will be cemented and packaged for disposal to WIPP. Any residual calcium metal will be reacted with water prior to cementation.

Miscellaneous combustibles will also be dispositioned for disposal following pretreatment by pyrolysis if necessary. Pyrolysis of this material may increase the plutonium content beyond $50 \mathrm{wt} \% \mathrm{Pu}$. This material would then be 
subject to DOE-STD-3013 criteria for long-term storage. For combustibles containing less than 50 wt\% Pu, limited PPSL development testing is anticipated to permit the disposition of this material.

Many of the items currently stored in PFP's vaults are not fully characterized. Specifically, there is a lack of information regarding the non-plutonium constituents. Some chemical characterization will be required to stabilize or discard this material in accordance with the characterization implementation plan which is now being implemented as described in Section 3.7. Upgrades to the PFP laboratory have been identified to provide characterization capability, and these upgrades are included in Section 3.5.

3.3.3.1 Preparation. Polycube Stabilization: The preparation phase for polycube stabilization includes an engineering study completed in July 1996 and a development program for the polycube stabilization system (Project $C$ 227). The development program is intended to gather information to select and design a polycube stabilization method. The engineering study documents the test data collected and the decisions made, and will serve as a key input to the conceptual design process.

The stabilization method under development as Project $\mathrm{C}-227$ is pyrolysis with off gas treatment. Three off gas treatment methods for pyrolysis were being considered: catalytic conversion, silent plasma discharge and secondary combustion. Process preparation activities are underway as follows:

- Testing began concurrently for the three off gas treatments. These tests were used to gain information to support the decision process and eventual implementation of the selected method. Following the completion of testing, silent plasma discharge was selected as the pyrolysis off gas treatment method. FDC and CDR processes have recently been completed for this method.

- Safety analysis for the polycube stabilization process will ensure safe operation and provide the proper safety documentation to comply with DOE orders (DOE 5480.22 and DOE 5480.23) and contractor management policies. Compliance with these requirements will help ensure the protection of the environment and the employees; members of the general public are not subject to undue risk.

- Procurement activities have begun to obtain a "turnkey" system from LANL. Following procurement, a key decision to proceed will be made, and the installation of equipment, development of procedures and the training of the operating personnel will begin.

- Readiness assessment scoping will be done to establish the breadth and depth of the readiness assessment prior to startup of the polycube stabilization process.

The readiness assessment will be conducted by the contractor in accordance with established contractor readiness process procedures and DOE Order 5480.31. This readiness process shall focus on the adequacy of hardware, personnel, and the administrative process necessary to support and maintain the safe operation of the stabilization activity. After the readiness process 
is completed and readiness is verified, DOE/RL will provide written authorization to proceed with the polycube stabilization program work to plant management. Completion of the readiness process concludes the preparation activities required prior to startup of the polycube stabilization process.

Preparation for Disposal: Vault-stored process residues, with some material generated by terminal cleanout activities, will be cemented and prepared for disposal to WIPP. All high-risk ash items at PFP have been stabilized and packaged to DOE interim safe storage criteria. Sand, slag, and crucible will be reacted with water. Installation of cementing equipment in HA-20MB will be completed in August 1996.

3.3.3.2 Production. Polycube Stabilization: Startup processing of the polycube stabilization process will be initiated in July 1999 and will fulfill the requirement of Milestone "IP-3.3-028; Stabilization of Polycubes begins." Completion of the polycube stabilization process will occur in May 2000. Completion of this activity will fulfill the requirement of Milestone "IP-3.3029; Stabilization of Polycubes completed." This material will be packaged to the interim storage criteria if the Stabilization and Packaging System (Project W-460) is not available. Completion of these milestones will be documented by letter to RL.

Stabilization of Residues: Thermal stabilization of residues will occur in the muffle furnaces. Five furnaces (including the two existing furnaces) are expected to bring PFP's total processing capacity to about $1,500 \mathrm{~kg}$ per year. Completion of this activity in March 1998 will fulfill the requirement of Milestone "IP-3.3-026; Stabilization of reactive solids (SS\&G) completed."

Thermal stabilization of other oxide residues containing less than $50 \mathrm{wt} \%$ plutonium will also begin in May 1997 and will conclude in April 2000. Completion of this activity will fulfill the requirements of two milestones: "IP-3.3-027; Stabilization and repacking of interim-stabilized materials completed", and "IP-3.3-033; Stabilize and package all remaining residues to safe interim storage standards." Completion of these milestones will be documented by letter to DOE-Rt.

Preparation for Disposal: SS\&C, low grade oxides, combustibles, ash, plutonium compounds, and miscellaneous plutonium bearing materials will be immobilized in cement and packaged to meet regulatory requirements for eventual shipment and storage in WIPP. Because SS\&C contains residual calcium metal residual which reacts with water, SS\&C will be reacted with water prior to cementation.

The residue material will be transferred into a glovebox in PFP where the container is opened, weighed, and processed through a size reduction unit. measured amount of residue material is added to chilled water in a mixer reactor (an industrial model mixer with a bowl capacity of a nominal five liters). After mixing, the solids will be separated from the excess liquid (which is recycled) and the remaining slurry will be mixed with cement. Cement cans will be sized to make efficient use of the storage container. When the cement is cured, it is sealed out of the glovebox, packaged, and shipped. 


\subsubsection{Schedule objectives}

A detailed schedule for sludges and other miscellaneous solid residues is shown in Appendix B of Volume 2 of this report. Highlights of the schedule are as follows:

- The stabilization of the original inventory of 236 low organic sludges was completed via the two existing muffle furnaces in June 1995. Sludges or residues recovered from PFP terminal cleanout activities will be stabilized and/or packaged for WIPP disposal in the same year they are generated, starting in October 1995, using either the two existing muffie furnaces or the cementation process coming into service in September 1996.

- Details for stabilization of the polycubes are shown on the attached schedule in Volume 2 of the SISMP. The polycube pyrolysis equipment (Project C-227) will be operational by July 1999. All polycubes should be stabilized by May 2000. The material will be packaged for storage to meet DOE-STD-3013 criteria.

- The pyrolysis system may be used to pretreat compatible miscellaneous combustibles if required for discard. Miscellaneous combustibles will be evaluated for disposition as waste to WIPP by July 1999.

- The PFP Analytical Laboratory is expected to be upgraded by December 1997. Additional instrumentation will be provided to support necessary analyses in characterization of miscellaneous solid residues and process support of the stabilization operations.

\subsubsection{Assumptions}

The following assumptions are made in developing the "Residues and 0xides" portion of the SISMP.

1. The base case stabilization of plutonium residues (SS\&C, ash, low-grade oxides, combustibles, and other miscellaneous residues) will be cementation and discard as TRU waste to WIPP. Other cost-effective options may be identified by the residue trade studies currently underway.

2. Dose rates associated with the residue stabilization effort will be manageable given the WHC/DOE administrative Timit of 1,500 mrem exposure per year. A dose evaluation was completed to confirm this assumption.

3. DOE will be successful in negotiating Tri-Party Agreement (TPA) commitments to allow the cementation of residue materials and their discard as TRU waste where cost-benefit analysis indicates this witl be acceptable.

4. Stabilization operations will be on a 24-hour-per-day, 5-day-per-week basis, and personnel and funding will be provided to support this level of effort. Cementation throughput will be $130 \mathrm{~kg} / \mathrm{month}$. 
5. Integration of stabilization and facility deactivation activities (including terminal cleanout operations) will continue to provide the opportunity for efficient personnel resource allocation during stabilization process slowdowns.

6. RL will have the authority to remove safeguards from selected residue material for purposes of discard.

7. Sources containing less than $50 \mathrm{wt} \%$ plutonium will be transformed to stable oxides. Alloys will be repackaged for long-term storage.

8. MOX residues will be evaluated for discard to WIPP.

\subsubsection{Issues and Problems}

The following issues and problems have been identified that could affect the ability of the residue stabilization program to meet its program objectives.

1. Many of the items currently stored in PFP's vaults are not fully characterized. Specifically, there is a lack of information regarding the non-plutonium constituents. Some chemical characterization will be required to stabilize or discard this material in accordance with the characterization implementation plan which is now being implemented as described in Section 3.7.

2. DOE approval of a strategy to discard a significant fraction of the miscellaneous solid residue as TRU solid waste will expedite completion of the stabilization effort. However, the suitability of some miscellaneous solids for disposal as TRU waste must be verified. At the same time, space allocations in the WIPP must be made to ensure adequate capacity at the facility to receive TRU waste from PFP.

3. The residue trade studies do not cover all residue materials at Hanford, such as MOX materials. Additional analysis to address long term packaging and storage of stable MOX material is needed.

4. The PFP Environmental Impact Statement (EIS) does not allow highgrading, an option currently being evaluated in the ash trade study. If the trade study recommends this option, PFP does not currently have the NEPA coverage to permit implementation.

\subsubsection{Alternatives/Impacts}

In order to mitigate the cost, schedule, safety and technical issues associated with Section 3.3.6, PFP has developed the following options and alternatives.

1. The on-going trade studies for sand, slag, and crucible (SS\&C), and ash will provide processing alternative recommendations to be considered by this program. For SS\&C, two options are being considered: shipment of 92 cans of SS\&C from Hanford to LANL for treatment with the remaining SS\&C undergoing disposal at WIPP, and cementation of all SS\&C at Hanford. Cementation of all SS\&C at Hanford is the current base case. 
While currently not as mature as the SS\&C trade study, the ash study is considering two main options: processing via silver persulfate for storage in the PFP vaults, and cementing for eventual disposal at WIPP. However, PFP does not currently have the separations capacity required to high-grade residues to oxides as required for the silver persulfate option. Nor does the Record of Decision from the PFP EIS authorize this approach. The recommendations of the ash trade study final report may impact consideration of ash and combustibles issues at PFP. The precise extent of these impacts cannot be determined at this time.

\subsubsection{Technology Development}

- The stabilization of sludges and ashes has proven the muffle furnace technology to support stabilization of other plutonium-bearing materials both from Hanford facilities and from other sites as required.

- Hydrolysis of organic-bearing materials has been practiced at PFP and elsewhere and needs no specific development.

- Hanford and LANL are cooperating on the development of a polycube stabilization method. The method being developed at LANL is pyrolysis with off gas treatment. Three off gas treatment methods were considered: catalytic conversion, silent plasma discharge and secondary combustion. The silent plasma discharge method was chosen in July 1996. Completion of the LANL development activities is expected when the prototype demonstration at LANL is completed in October 1996.

- No technology development in support of the silver persulfate option is currently planned, funded, or authorized.

\subsection{METALS AND OXIDES}

\subsubsection{Scope}

This material category includes the PFP's current inventory of plutonium metals and oxides material of greater than 50 wt\% plutonium. High-assay oxides and plutonium metals at PFP consist of three groups: oxides of greater than 50 wt\% Pu, mixed oxides (MOX) of greater than 50 wt\% plutonium plus uranium, and metals. The metals and oxides category covers approximately 2,999 items and approximately $2,600 \mathrm{~kg}$ of plutonium, including approximately one ton of material which is currently under International Atomic Energy Agency (IAEA) safeguards. An equivalent amount of material will remain under IAEA safeguards while stabilization and repackaging occur. This category also covers the $1.2 \mathrm{~kg}$ of material received from Mound in July 1996.

\subsubsection{Remediation Objectives and Endstate}

The objective of this remediation is to transform the plutonium metal and oxide materials to a stable form suitable for long-term storage in accordance with DOE-STD-3013. This objective will be accomplished by Project $W-460$, Plutonium Stabilization and Handling (PUSH), which encompasses several related 
activities to assure the safe storage of high-assay plutonium remaining at PFP for up to fifty years.

-3.4.2.1 Concept of Operations. All high grade oxides and metals will be thermally stabilized and repackaged to DOE-STD-3013 criteria. However, there are minor differences in the processing paths of each material type as follows:

- Metals: Metals stored at PFP are typically high in Pu-240 and have a heat output per container which renders long-term storage as metal noncompliant with DOE-STD-3013. These metals will therefore require oxidation to stabilize them prior to packaging. The oxidation will be done in five muffle furnaces located in the 234-5z Building. Two furnaces are currently operational, while an additional three furnaces will be installed by December 1996, to be operational by June 1997 . Existing gloveboxes will be used for loading and unloading the furnaces. LOI testing will occur in an existing glovebox equipped with a new thermo-gravimetric analysis (TGA) system. Since the metals will be oxidized before the SPS is operational, the resultant oxides will be canned to interim storage criteria and stored in the PFP vaults until repackaging to DOE-STD-3013 criteria can occur in the SPS.

- Oxides: 0xides will be stabilized and repackaged in the SPS unless they are found to contain impurities which make automated stabilization and handling undesirable. Materials for which this is the case will be thermally stabilized in the muffle furnaces in 234-5Z, canned and transferred to $2736-2 B$ for outer packaging to DOE-STD-3013 criteria in the SPS. Characterization and process testing will determine which items, if any, of PFP's oxide inventory are not compatible with the SPS.

- Mixed Oxides (MOX): MOX elements including pellets, powders, and scrap with greater than 50 wt\% plutonium plus uranium are not within the scope of DOE-STD-3013. Hanford will develop the technical basis and stabilization criteria for safe storage of MOX in the DOE-STD-3013 container. It is assumed that the thermal stabilization criteria in DOE-STD-3013 will be sufficient for long-term storage of MOX. As is the case with oxides, some MOX items may not be compatible with the SPS. These incompatible items will be stabilized in the five muffle furnaces, canned and transferred to the SPS for packaging in the DOE-STD-3013 container prior to storage in the vaults.

\subsubsection{Remediation Processes}

Stabilization of metals will be done in the five muffle furnaces. The resultant oxide will be canned to the interim storage criteria and stored in PFP's vaults until repackaging to DOE-STD-3013 criteria can occur in the SPS. The oxides and MOX materials will be stabilized and packaged in the SPS unless they are found to contain impurities which make automated stabilization and packaging undesirable. Materials for which this is the case will be thermally stabilized in the muffle furnaces in 234-5Z, canned and transferred to $2736-\mathrm{ZB}$ for outer packaging to DOE-STD-3013 criteria in the SPS. 
MOX will be stabilized to a technical basis developed by Hanford that is compatible for storage in the DDE-STD-3013 container.

3.4.3.1 Preparation. Muffle Furnaces: For the two muffle furnaces currently installed at PFP, operations are ongoing and no preparation activities are required. In order to prepare for installation of three additional muffle furnaces to increase the plant's stabilization capacity, the following preparation activities are required:

- The preparation phase for the three muffle furnaces began in May 1995, with design for the gloveboxes and room in which the furnaces will be located. A safeguards and security evaluation was completed for the area selected to receive the three furnaces. This evaluation defined required security upgrades for the thermal stabilization area. These activities will be completed in December 1996.

- The preparation of safety analysis documentation will ensure safe operation and compliance with relevant DOE Orders (DOE 5480.22 and DOE 5480.23 ) and contractor management policies. Compliance with these requirements will ensure the protection of the environment and workers. Members of the general public are not subject to undue risk.

- Other ongoing or pending preparation activities include procurement and site preparation, security improvements, installation of the furnaces, development or revision of procedures to operate the furnaces, operator training, and testing.

- Readiness assessment scoping began in August 1996 to establish the breadth and depth of the assessment. The readiness assessment will be conducted by the contractor in accordance with established contractor readiness procedures that ensure compliance with DOE Order 5480.31. No $\mathrm{RL}$ review is planned at this time. After the readiness process is completed and readiness is verified, the contractor will proceed with operation of the furnaces. Completion of the readiness process concludes the preparation activities required prior to startup of the three new muffle furnaces.

Stabilization and Packaging System: Several related actions in preparation for SPS operation are encompassed by Project W-460. A key interface exists between SPS operation and vault modifications required to upgrade containment and surveillance (C/S) and support DOE-STD-3013 long-term storage following SPS processing activities. Preparation activities critical to success include the following:

- A location assessment for the SPS was completed in June 1996. Rooms 641 and 642 in 2736-ZB Building were chosen for placement of the SPS.

- Functional Design Criteria development for SPS installation and vault modifications was completed in July 1996. Conceptual Design Requirements development is underway.

- Site preparation activities are required for Rooms 641 and 642 . Current functions which utilize these areas will be relocated, which may require 
some construction within the building or potential installation of a mobile office unit. Structural preparations such as enhanced lighting and a temporary large equipment access will be made. The building ventilation system capacity will be verified and enhanced if necessary. The capacity of utilities required for operation of the SPS will be verified; for existing utilities such as electrical power, reconfiguration or enhancement may be required. For other utilities such as nitrogen gas, a supply system will be installed.

- Surveillance equipment and international safeguards equipment currently in Room 642 will be relocated within the building to make space available for the SPS. Laboratory characterization equipment related to the packaging unit will be purchased and installed. It is anticipated that a radiography unit will be required for weld signatures and contents baselining. One to three (based on SPS processing rate) calorimetry units will be purchased to accommodate the new DOE-STD-3013 package configuration, along with related equipment. Site preparation for these items will be undertaken in sequence to minimize disruptions to non-destructive analysis (NDA) laboratory operations.

- $\quad V i a$ the common procurement agent (currently DOE Oakland), the design of the prototype SPS unit to be tested at Rocky Flats during 1997 will be modified to suit Hanford's needs, constructed, installed, and tested. It is anticipated that the vendor will install the SPS equipment. Certain surplus equipment currently at the Hanford Site will be used as feasible in the system, e.g. a glovebox for size reduction of impure oxide forms. Initiation of the complex-wide procurement completed the requirements for Milestone "IP-3.2-028; Start engineering studies. of a new repackaging 1 ine at Hanford." Completion of the installation will fulfill the requirement of Milestone "IP-3.2-029; Complete detailed design, equipment procurement, and installation of a new repackaging system at Hanford."

Within the SPS, items to be procured will include approximately thirteen gloveboxes and fume hoods with associated ventilation and service connections, three muffle furnaces, laser and electrostatic welding machines, a variety of automated material movement equipment and a system control unit. An initial order of DOE-STD-3013 packaging components will be procured for equipment testing and qualification.

- Secure vault storage in Building $2736-Z$ will be modified to accommodate DOE-STD-3013 packages. A minimum of two vault rooms must have equipment modified, and a third is anticipated. While fixtures, vault walls, floors, and ceilings will remain, the vault interior will be replaced. Security items such as bars, cages, seał holders and some electronic equipment will also be added, based on domestic and international containment and surveillance requirements. Operational sequencing (i.e., emptying Room $A$ into another room) will be required to allow construction access while minimizing radiological dose.

- A readiness assessment will be conducted by the contractor for the Project $W-460$ in accordance with established contractor readiness process procedures that ensure compliance with DOE Order 5480.31. This 
readiness process shall focus on the adequacy of hardware, personnel, and the administrative process necessary to support and maintain the safe operation of the SPS and storage vaults. After the readiness process is completed and readiness is verified, RL will provide written authorization to proceed with SPS operation to plant management. Completion of the readiness process ends the preparation activities required prior to startup of the SPS. Completion of the readiness assessment fulfills the requirement of Milestone "IP-3.2-030; Train staff, prepare procedures, perform operational readiness testing (prior to commencing operations." Completion of these milestones will be documented by letter to RL.

\subsubsection{Production. Muffle Furnaces: Startup processing of the three} muffle furnaces will occur in January 1997. These three furnaces will have a throughput capacity of about $900 \mathrm{~kg}$ of bulk solids per year. Processing capability for the five furnaces (including the two existing furnaces) is expected to be about $1,500 \mathrm{~kg}$ per year. Following use of the muffle furnaces to stabilize residue items, the muffle furnaces will begin to stabilize metals and impure oxides incompatible with the SPS in January 1997. These materials will later be repackaged to DOE-STD-3013 criteria in the SPS. This activity will fulfill the requirement of Milestone "IP-3.2-033; Start restabilizing high assay oxides at the PFP."

Stabilization of the oxides will require only the high-temperature soak period in the furnace. The stabilized product will be allowed to cool in a controlled environment and then repackaged in the SPS to DOE-STD-3013. Material processed before the SPS is operational will be packaged to interim safe storage criteria and then repackaged later in the SPS to DOE-STD-3013 long-term storage criteria.

Completion of high assay oxide stabilization using both muffle furnaces and SPS as appropriate is planned by January 2002. Completion will fulfill the requirement of Milestone "IP-3.2-034; Complete restabilizing high assay oxides at the PFP." Completion of both milestones will be documented by letter to RL.

Stabilization and Packaqing System (Project W-460): The SPS will stabilize and repackage high-assay oxides and compatible MOX elements beginning in October 1999. The SPS will also be used to repackage alloys and other items stabilized in the muffle furnaces to DOE-STD-3013 criteria for long-term storage. SPS operation will take place over three shifts per day, five days per week. Approximately three tons of Pu will be stabilized and/or canned in the SPS. This includes the material currently under IAEA safeguards at PFP. The material under safeguards will be processed through the SPS in 14 weeks.

SPS operation will fulfill the requirement of Milestone "IP-3.2-031 Commence repackaging operations at Hanford." Interim milestones are also associated with SPS operation as follows:

- Stabilization of metals in the muffle furnaces will be completed by May 1997. Repackaging of alloys and oxides (formerly metals) in the SPS will be completed by September 2000 . Completion of this activity will 
fulfill the requirement of Milestone "IP-3.2-032; Complete Metal Repackaging at Hanford."

- Completion of stabilization and repackaging of all oxides and alloys will fulfill the requirement of Milestone "IP-3.2-018; Thermally Stabilize and Repackage all Plutonium 0xide to meet the Metal and oxide Storage Standard." This activity will be completed by May 2001.

- As stated above, completion of high assay oxide stabilization using both muffle furnaces and SPS by May 2001 fulfills all milestones associated with DNFSB Recommendation 94-1. Completion of these milestones will be documented by letter to RL.

\subsubsection{Schedule Objectives}

A detailed schedule for stabilization and repackaging of metals and oxides is contained in Volume 2 of the SISMP. Highlights of the metals and oxides schedule are as follows:

- Readiness assessment for the muffle furnaces will be completed in December 1996.

- By February 1997 the Conceptual Design Requirements for vault modifications will be completed, incorporating IAEA input as necessary to ensure compatibility with IAEA containment and surveillance requirements.

- By January 1998 the SPS machine will be ordered and by December 1998 the vendor will install it at PFP.

- By September 1999 the SPS will be operational.

- Stabilization of metals will be completed by June 1997 .

- The oxides will be stabilized starting in July 1998 and processing completed in early 2001.

- By May 2001 all at-risk materials at PFP will be stabilized and repackaged to DOE-STD-3013 requirements.

\subsubsection{Assumptions}

The following assumptions are used in the development of the management plan for the metal and oxides schedule.

1. Capital line item funding will be provided for Project W-460, "Plutonium Stabilization and Handling" to enable SPS procurement and installation and associated vau?t modifications.

2. Total throughput for the five muffle furnaces is expected to be roughly $1,500 \mathrm{~kg}$ of plutonium per year. Throughput for the SPS is expected to be approximately $1,800 \mathrm{~kg}$ of plutonium per year. 
3. All metals will be thermally stabilized to oxides and stored to meet DOE-5TD-3013 criteria.

4. DOE-STD-3013 criteria will be appropriate for stabilization and longterm storage of mixed oxides.

5. Approximately one ton of plutonium will remain under IAEA safeguards at PFP. IAEA feedback must therefore be a fundamental input to program planning from conceptual design through construction to operation. A dialogue will be initjated and maintajned among PFP, DOE, and the IAEA to facilitate ongoing IAEA input into relevant $94-1$ activities at PFP.

6. No commingling of safeguarded with non-safeguarded material will take place without prior IAEA approval.

7. No additional material will be offered for IAEA safeguards at PFP until it has been stabilized and repackaged.

\subsubsection{Issues and Problems}

The following issues and problems have been identified that could affect the ability of the stabilization program for metal and oxides to meet its objectives.

1. Many of the items currently stored in PFP's vaults are not fully characterized. Specifically, there is a lack of information regarding the non-plutonium constituents. Some chemical characterization will be required to allow safe stabilization or discard of this material in accordance with the characterization implementation $\mathrm{plan}$ which is now being implemented as described in Section 3.7 , and will not impact current schedules.

2. The presence of approximately one ton of material under IAEA safeguards requires integration of IAEA safeguards with stabilization activities. Significant policy, ES\&H and resource allocation issues are associated with application of IAEA safeguards during stabilization. Discussion is underway with DOE, the IAEA and other impacted sites in the DOE complex to identify the least costly and least resource intensive safeguards option which meets the requirements of US nonproliferation policy.

3. The SPS machine currently operational at the BNFL THORP facility in Sellafield, England is processing a physically homogeneous inventory of pure oxides with greater than $85 \mathrm{wt} \% \mathrm{Pu}$. The heterogeneous inventory at PFP stands in contrast to current SPS operating experience. For this reason, process holdup cannot be quantified at present. This has potential international safeguards implications, and other uncertainties may emerge as the PFP inventory is processed in the machine. 


\subsubsection{Alternatives/Impacts}

1. Oxides items greater than 50 wt\% Pu which are incompatible with the SPS in their current form will be stabilized in the muffle furnaces and repackaged in the SPS to DOE-STD-3013 requirements as appropriate.

2. Two broad a]ternatives are currently under consideration for the integration of IAEA safeguards at PFP: application of safeguards to the SPS to maintain the material under constant IAEA control; and replacement of an isotopically equivalent amount of thermally stabilized plutonium for the ton under safeguards so that the current inventory under IAEA safeguards may be stabilized without safeguards. A policy decision is required by December 1996 so that IAEA requirements such as sample ports for the SPS may be ordered without delay to the programmatic schedule.

\subsubsection{Technology Development}

1. Functional Design Criteria for SPS installation and associated vault modifications were completed in July 1996. Development of Conceptual Design Requirements is currently underway and expected to be complete in February 1997.

2. No technology development needs are associated with the installation of three new muffle furnaces at PFP.

\subsection{SUPPORT SYSTEMS}

\subsubsection{Scope}

This category includes the PFP Analytical (PFPAL), and the Security and Safeguards (S\&S) support systems necessary to implement this portion of the Hanford SISMP which are not directly related to a specific material category. A significant portion of PFP's current inventory of plutonium-bearing material is expected to be subject to DOE-STD-3013. To implement DOE-STD-3013, PFP will need to: (1) install a new stabilization and packaging system (Project $W-460)$; and (2) modify the existing vault storage arrays to accept the new package. To support these activities:

- The existing safeguards and security (SAS) systems will need to be modified to support SPS operation and vault modifications, to reduce the frequency of required IAEA inspections, and to maintain reliability for the next 20 years of storage.

- The current laboratory capabilities at the Hanford Site will require upgrades to support the necessary characterization and analys is of TRU materials and wastes by determining the appropriate disposition path and prioritizing stabilization activities for specific items by risk.

- Depending on the outcome of the DOE Materials Disposition PEIS, additional upgrades to the $2736-Z$ and $2736-2 B$ facilities may be required. 


\subsubsection{Support objectives}

The objectives of these support systems are: 1) to enable the facility to transform the plutonium-bearing materials to a stable form, typically oxide, suitable for long-term storage; 2) to provide the necessary hardware to implement the DOE-STD-3013 packaging standard; and 3) to maintain a safe and compliant facility which supports the DOE mission. Additionally, these support systems will enable the facility to discard those items that are determined to be waste in full compliance with state and federal regulations.

\subsubsection{Support Systems Descriptions}

The required support system modifications can be broken down into three categories:

1. Support requirements for installation of the Stabilization and Packaging System and associated vault modifications to allow for the implementation of DOE-STD-3013 and improved $\mathrm{C} / \mathrm{S}$.

2. Upgrades to the existing PFP laboratories to enable complete characterization of plutonium-bearing materials and waste as needed.

3. Modernization of the existing SAS systems to provide maintainable remote inventory and surveillance capabilities.

All proposed modification projects are being screened to ensure that they support the general transition of the PFP complex towards deactivation and are necessary to achieve an acceptable level of reliability.

Due to the scope of the work required and the associated cost, one line-item-funded project is envisioned for the new SPS and associated vault modifications. The SAS system modernization is expected to be expense-funded replacement-in-kind. The laboratory upgrades are expected to be within the constraints of a general plant project (GPP).

\subsubsection{Schedule Objectives}

Key schedule objectives for support services upgrades are as follows:

- Engineering work on the SAS modernization is well underway. The SAS project is currently funded for FY 1995 and FY 1996 with contingent funding in FY 1997. An estimate will be prepared for the laboratory upgrades with the goal of obtaining GPP funding for 1997.

- The SPS and associated vault modifications will require additional engineering prior to development of a validated cost estimate. Reprogramming of an existing line item (FY 1998, \$18 million for PFP SAS upgrades) will be required to meet the programmatic goal of completion of the repackaging by May 2002. 


\subsubsection{Assumptions}

The following assumptions are used in developing the support systems portion of the Hanford SISMP.

1. The consolidated development and procurement activity currently underway at $\mathrm{DOE}-\mathrm{HQ}$ will provide a functional system which PFP can procure in October 1997 (FY 1998 funding) and have fully operational by June 1998.

2. If IAEA safeguards are determined to be required for the SPS machine, policy guidance from DOE-NN and safeguards requirements input from the IAEA will be received by December 1996, and on an ongoing bas is thereafter, to permit incorporation in the SPS Conceptual Design Report and subsequent design submittals.

\subsubsection{Issues and Problems}

No specific issues or problems have been identified in this area. The SPS is being developed through a consolidated development and procurement effort.

\subsubsection{Alternatives/Impacts}

The development and procurement of the packaging system is being coordinated by DOE-HQ. No alternatives are being considered locally. Hanford will continue to stabilize material and store it to Hanford's current criteria until such time as DOE-STD-3013 compliant long-term storage is available.

\subsubsection{Technology Development}

The SPS is currently undergoing formulation of the CDR at PFP. This activity is scheduled to be complete in February 1997. The vendor will respond to these requirements when preparing the SPS for installation.

Calorimeters are currently under development which are capable of performing non-destructive assay on DOE-STD-3013 cans. This design is expected to be available and validated by the IAEA by August 1997.

No other technology development activities for support systems are planned at this time.

\subsection{DOSE EVALUATION}

The preliminary stabilization and cleanup rates in the SISMP did not consider the radiation dose on the workers, and it was uncertain whether individual doses could be held within the administrative limit of 1,500 mrem per year with all systems operational and at projected staff levels. A dose evaluation engineering study on the overall system was performed to address this issue. The study was completed in June 1996 and determined that individual dose requirements may be held within the administrative limit. 


\subsection{CHARACTERIZATION OF PLUTONIUM-BEARING MATERIALS}

Containers of plutonium-bearing materials shall be classified according to their content and container integrity into the following categories:

- Meets stability requirements of current Hanford Storage Specifications and will meet Interim Storage Criteria as is.

- Meets stability requirements of current Hanford Storage Specification but would require repackaging to meet Interim Storage Criteria.

- Needs thermal stabilization to meet Interim Storage Criteria or DOE-STD-3013 requirements.

This characterization shall be done by:

- Reviewing the documentation on the contents of each container.

- Assessing the material and container in accordance with the above categories

- Conducting radiography of selected containers to gather data on material and containment conditions

- Where necessary, sampling and analyzing the contents of the container and the container itself to make the above determination.

An inventory characterization implementation plan has been prepared to establish the framework for performing this characterization. Detailed work plans will be used to provide specific work instructions for the selection of items to be examined and direct the analyses to be performed. The first phase work plan implementation was conducted in March 1996. It included provision to perform digital radiography on all selected containers and based on those results detailed container examinations and chemical analyses were conducted. Evaluation of these data will form the basis for subsequent phases to provide finer granularity to the characterization of the inventory.

This effort will provide a risk basis for the sequencing of repackaging or stabilization to ensure continued safe storage as well as minimize risk during storage until disposition is complete. This will also ensure the proper stabilization process is used on each item. 


\subsection{PLUTONIUM FINISHING PLANT FINAL SAFETY ANALYSIS REPORT REVISION}

PFP received approval for the FSAR after a four-year approval process. The scope of processing and cleanout activities listed in the DNFSB Recommendation 94-1 SISMP will necessitate a revision to the PFP FSAR. This revision is currently underway and will be submitted to DOE for approval by September 30 , 1996. Only Chapter 9, "Accident Analysis", requires DOE approval prior to incorporation in the authorization basis. Subsequent authorization basis changes to support stabilization and repackaging will be captured in annual revisions to the FSAR. The revised FSAR will enable PFP to meet its programmatic goals for the 94-l program.

\subsection{INTERNATIONAL ATOMIC ENERGY AGENCY INTERACTION}

Approximately one ton of PFP's plutonium inventory is currently under IAEA safeguards. In accordance with US nonproilferation policy, additional material may be offered for Agency safeguards in the future. For these reasons, the IAEA interface is critical to the success of PFP's 94-1 implementation program. In conjunction with 94-1 stabilization activities, PFP will also be installing vault modifications to facilitate DOE-STD-3013 compliant storage. With DOE and Department of State assistance, the plant is seeking IAEA input regarding key interfaces that exist between its PUSH program, planned vault modifications, and potential IAEA safeguards regimes that could be utilized to stabilize the material currently under IAEA safeguards. Three areas of concern require programmatic/policy resolution before international safeguards can be effectively integrated into the PUSH planning process. In summary, these are:

1) US policy regarding integration of IAEA safeguards and stabilization activities at PFP. This decision must take into account the nonproliferation objectives, ES\&H priorities and resource allocation issues associated with application of international safeguards during stabilization. Several safeguards options are currently being discussed with DOE and the IAEA.

2) Selection of containment and surveillance option for vault modifications. Enhanced IAEA C/S features installed during planned vault modifications will greatly simplify future IAEA inspection regimes at PFP in terms of less frequent and less intrusive inspections. PFP is considering an upgrade to "triple $C / S$ " because of the world-wide experience of frequent $C / S$ failure. IAEA input is sought in this regard.

3) Use of Non-Destructive Assay for IAEA Safeguards at Hanford. The most accurate IAEA safeguards measurements have traditionally been obtained via weighing, sampling and destructive assay (DA) techniques which require opening sealed cans of plutonium. Recent developments suggest that calorimetry, a non-destructive assay (NDA) measurement technique, may present a more viable option for highly-accurate bias defect measurements, given the highly heterogeneous quality of the Hanford plutonium inventory. Use of calorimetry also offers worker safety, cost 
and schedule advantages. IAEA input is sought to determine whether calorimetry may be accepted for these purposes and whether the IAEA may obtain use of calorimeters which are compatible with DOE-STD-3013 cans.

Agency input will be critical to the success of IAEA safeguards/94-1 integration. Several key input points have been identified and are currently being incorporated in the Project $W-460$ schedule:

- By October 1996 PFP will submit its conceptual plans for vault modifications with IAEA safeguards to the Agency for review and comment. The layout plan for the SPS will also be submitted for Agency information at this time.

- By December 1996 PFP must receive Agency input for incorporation in the CDR. Therefore the IAEA safeguards protocol to be applied during stabilization and repackaging activities must be determined by that time. If IAEA safeguards will be applied during SPS operation, any significant design changes such as the addition of external sample ports with associated facility changes must be made at this time.

- By September 1997 PFP must receive final input from the IAEA for incorporation in the SPS detailed design.

\subsection{WORK PLAN}

Cost, schedule, and technical baselines for the plutonium-bearing materials covered by this SISMP are provided by this document. Cost and schedule performance will be monitored on a monthly basis, and variance reports will be submitted to RL by the PFP Program Manager on the tenth working day of each month. Each task or activity is covered by a schedule bar on the GANTT chart and by a WBS Cost Account. A PFP Cost Account Manager is assigned to each activity and is responsible for cost and schedule performance under that activity. The PFP Cost Account Manager will report his performance to the PFP Program Manager on the first of each month. The variance report by the PFP Program Manager will cover any variation between the baseline and actual schedule or cost account with explanation and plans for necessary corrective action. The technical baseline is subject to formal change control and cannot be changed without the change control process.

The Program baseline is reviewed and changed as necessary every six months. The formal change control process will govern any change to the Program baseline.

Funding requirements to meet DNFSB Recommendation 94-1 IPP commitments for PFP are shown in Table 3-3. The total project costs are identified for reference purposes. 
WHC-EP-0853 ReV. 3

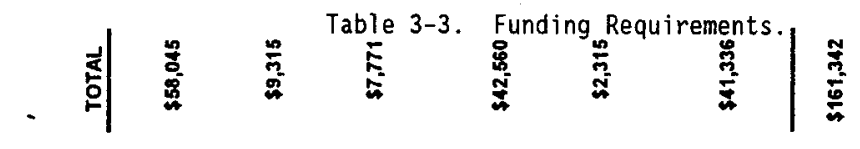

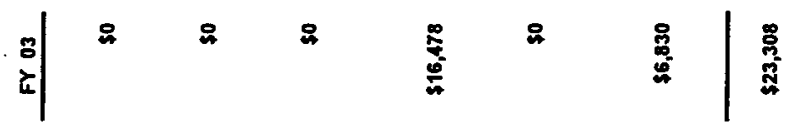

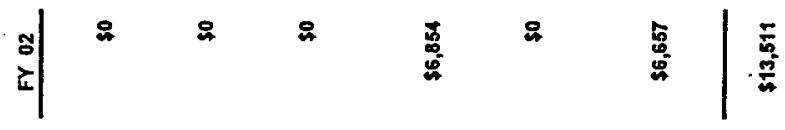

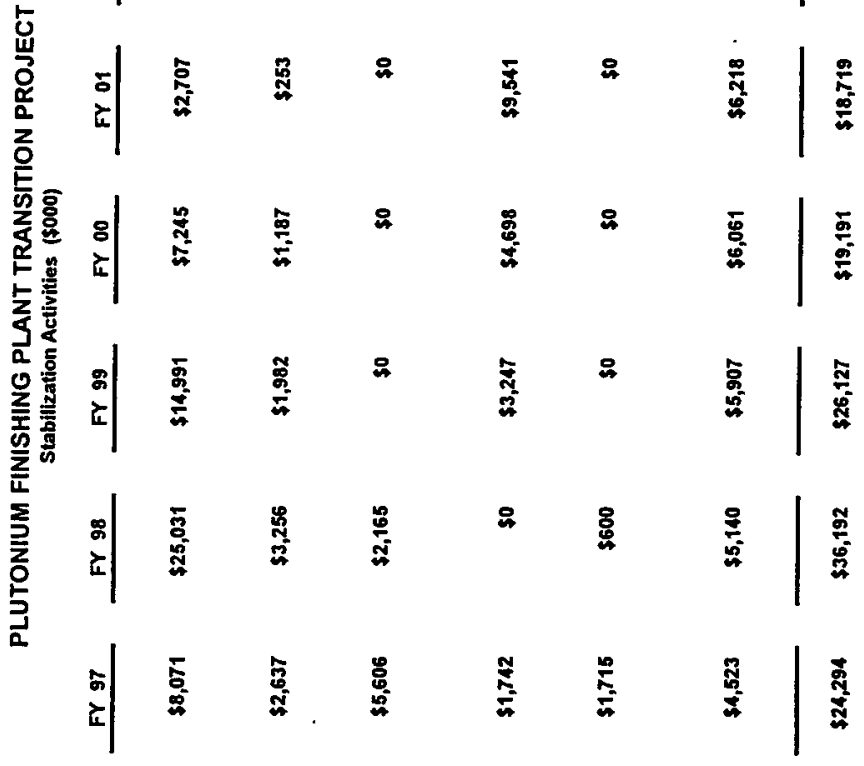

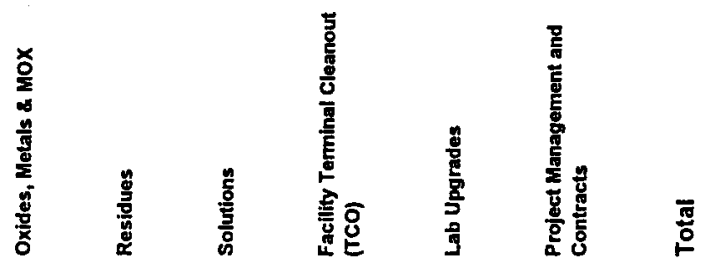


WHC-EP-0853 Rev. 3

This page intentionaliy left blank. 


\subsection{REFERENCES}

Bergsman, K. H., 1994, Hanford Spent Fuel Inventory Baseline, WHCSD-SNF-TI-001, Rev. 0, Westinghouse Hanford Company, Richland, Washington.

Brown, R. L., 1995, Spent Nuclear Fuel Canister Storage Building Startup Plan, WHC-SD-W379-SUP-001 (Draft), Westinghouse Hanford Company, Richland, Washington.

Conway, J. T., 1994, DNFSB Recommendation 94-1, (letter to H. R. O'Leary, U.S. Department of Energy, May 26), Defense Nuclear Facilities Safety Board, Washington, D.C.

DOE, 1993, DOE Spent Fuel Working Group Report on Inventory and Storage of the Department's Spent Nuclear Fuel and other Reactor Irradiated Nuclear Materials and the Environmental, Safety, and Health Vulnerabilities, U.S. Department of Energy, Washington, D.C.

DOE, 1994a, Plan of Action to Resolve Spent Nuclear Fuel Vulnerabilities (Phase III), U.S. Department of Energy, Washington, D.C.

DOE, 1994b, DOE Spent Nuclear Fuel Technology Integration Plan, SNFP-PP-FS-002, U.S. Department of Energy, Washington, D.C.

DOE, 1995a, Approval of Spent Nuclear Fuel (SNF) Path Forward Recommendation, (letter to A. L. Trego, Westinghouse Hanford Company, July 31), U.S. Department of Energy, Richland Operations Office, Richland, Washington.

DOE, 1995b, Approval of $K$ Basins Sludge Disposition Strategy, (letter to A. L. Trego, Westinghouse Hanford Company, June 13), U.S. Department of Energy, Richland Operations Office, Richland, Washington.

DOE, 1995c, Plutonium Vulnerability Management Plan for the Environmental, Safety and Health Vulnerabilities Associated with the Department's Plutonium Storage, DOE/EM-0199, U.S. Department of Energy, Washington, D.C.

DOE, 1995d, DOE-Owned Spent Nuclear Fuel Interim Storage Plan, D0E/SNF/PP-003 Rev. O, U.S. Department of Energy, Washington, D.C.

Ecology, EPA, and DOE, 1994, Hanford Federal Facility Agreement and Consent Order, as amended, Washington State Department of Ecology, U.S. Environmental Protection Agency, and U.S. Department of Energy, 0lympia, Washington.

Fulton, J. C., 1994, Hanford Spent Nuclear Fuel Project Recommended Path Forward, WHC-EP-0830, Westinghouse Hanford Company, Richland, Washington.

Idaho, 1995, Public Service Company of Colorado v. Batt, No. 91-0035-S-EJL (District Court of Idaho, October 17, 1995), (consent order). 
Lytle, J. E., 1994, Action: Approval of Path Forward for N-Reactor Spent Nuclear Fuel Interim Storage, (letter to T. P. Grumbly, November 9), U.S. Department of Energy, Washington, D.C.

O'Leary, H. R., 1995, DNFSB Recommendation 94-1 Implementation Plan, (letter to J. T. Conway, Defense Nuclear Facilities Safety Board, February 28), U.S. Department of Energy, Washington, D.C.

WHC, 1995a, Hanford Site Spent Nuclear Fuel Project Management Plan, WHC-SD-SNF-PMP-011, West inghouse Hanford Company, Richland, Washington.

WHC, 1995b, Integrated Process Strategy for $K$ Basins Spent Nuclear Fuel, Volume I: Strategy \& Recommendations (Draft), WHC-SD-SNF-SP-005, Westinghouse Hanford Company, Richland, Washington.

WHC, 1995c, Spent Nuclear Fuel Project Technical Baseline Document, WHC-SDSNF-SD-003, Rev. 0, Westinghouse Hanford Company, Richland, Washington.

WHC-CM-5-8, Plutonium Finishing Plant Administration, Volume 1, Westinghouse Hanford Company, Richland, Washington. 
WHC-EP-0853 Rev. 3

APPENDIX A

FACILITY DESCRIPTIONS

A-1 
WHC-EP-0853 Rev. 3

This page intentionally left blank. 


\section{APPENDIX A: FACILITY DESCRIPTIONS}

\section{KE and KW Basins}

The KE and KW Basins are located in the 100 Area of the Hanford Site. The basins are constructed of reinforced concrete walls and floors. The dimensions of each basin are 38 meters (125 feet) long, 20 meters (67 feet) wide, and 6 meters (21 feet) deep. The KE Basin walls are a constant thickness of $69 \mathrm{~cm}$. The KE Basin has neither sealant nor liner on its concrete. The KW Basin has an epoxy sealant, but no liner.

Each basin is enclosed by a one story steel framed building. The building also houses the water treatment and cooling systems. The roof structure of the steel frame includes a monorail fuel transport system. A personnel floor grating system covering the entire basin, is suspended from the roof.

Water levels are maintained in the $K$ Basins at a minimum of $3 \mathrm{~m}$ above the irradiated fuel to cool the fuel and provide radiological shielding for personnel working in the facility. The water retention boundary extends into the auxiliary pits located on the east and west ends of the basins. The water in each basin is recirculated through a closed loop water-cooling system using mechanical chillers. Filters and an ion exchange system maintain basin water clarity and remove radionuclides. Used filters and spent ion-exchange system components are disposed of at the Hanford 200 Area Low-Level Waste Burial Grounds.

The fuel is stored in canisters on the bottom of the basins in single stacked storage racks. The canisters are approximately $74 \mathrm{~cm}$ high, have two cylindrical barrels which are approximately $23 \mathrm{~cm}$ in diameter, and normally contain 14 fuel elements. A significant fraction of the fuel has damaged cladding which occurred at reactor discharge or during subsequent fuel handling, or resulted from uranium metal oxidation during storage. The loss of cladding integrity allows soluble and gaseous fission products to be released into the canister water. The canisters used in the KE Basin do not have lids and thus allow free exchange of water between the canister and the basin. Some of the canisters in the KE Basin also have screen bottoms. All of the canisters in the $\mathrm{KW}$ Basin have closed lids and bottoms.

Using hoists and separately attached lifting rods, canisters can be moved along an underwater path which corresponds to the route of the interconnecting network of slots built into the floor-grating covers. The canisters can be shifted to and from the storage basins into the abutting pits or pickup station for subsequent unloading, loading, reviewing, or inspection operations as needed.

In the KE Basin, a significant amount of sludge has accumulated on the floor. The sludge consists of zirconium oxide, iron oxide, concrete grit, and other materials that have mixed with fission products and fuel pieces, the fuel pieces having escaped from open storage canisters or remaining from previous fuel encapsulation activities. 
The $K$ Basins each currently have about 25\% unused capacity (assuming no stacking), although encapsulation of the KE fuel and accumulated sludge would eliminate the unused capacity in the KE Basin. Fuel enrichment only up to $0.947 \%$ is allowed in the KE Basin because of the sludge accumulation on the basin floor.

Access to the $K$ Basins is by rail. Cask handling capability at the basins are similar and fairly restrictive. Crane capacity is 27 metric tons. Casks must be loaded under water and must be less than $2.6 \mathrm{~m}$ tall. The cask transfer pit is $2.1 \mathrm{~m}$ by $2.8 \mathrm{~m}$, but framework within the loading pit reduces the free clearance to $1.5 \mathrm{~m}$ by $1.2 \mathrm{~m}$. Also, only the transfer pit located on the south side of the basin is functional.

The 22l-T Building is a $259 \mathrm{~m}(850 \mathrm{ft}$ ) 1ong by $21 \mathrm{~m}$ (68 ft) wide by $23 \mathrm{~m}$ $(74 \mathrm{ft})$ high reinforced concrete canyon building. T Plant was originally designed for recovery of plutonium from defense production reactor fuel. The building consists of the canyon, three galleries, one shielded craneway and a "headend" facility. The canyon area consists of 37 cells and one railroad tunnel entrance/exit. Shielding walls made of $3-m-t h i c k(9 \mathrm{ft})$ reinforced concrete separate the cells from the electrical and pipe galleries. The operating gallery is separated from the canyon deck by a $1.5-\mathrm{m}$-thick $(5 \mathrm{ft})$ concrete wall that extends $3 \mathrm{~m}$ ( $9 \mathrm{ft}$ ) towards the ceiling. Most of the cells are covered by four 2-mthick $(6 \mathrm{ft})$ reinforced-concrete blocks. The original equipment has been removed from some to the cells. The 221-T Building canyon pool cell (Ce11 4) was modified for the storage of the PWR Core II irradiated fuel. This concrete cell has a fabric liner between white concrete and grey reinforced concrete.

Cell 4 is adjacent to the railroad tunnel and contains a $4 \mathrm{~m}$ wide by 8.4 meter long pool with a capacity of about 200,000 1. Filtered, demineralized raw water is used for the initial pool fill. An installed demineralizer provides make-up water to replenish pool water lost by evaporation. An ion exchange column, installed in a radiation shield near the pool, is provided for removal of radioactive contamination from the pool water and for maintaining water quality. Two pumps, each capable of providing a flow of $38 \mathrm{l} / \mathrm{min}$, are installed for recirculation of pool water through the ion exchange column and the water chillers. Two chillers, each capable of removing up to $133,000 \mathrm{~kJ}$ per hour of radioactive decay heat, are installed near the pool. One pump and one chiller will normally be on standby. A catwalk is placed $1.5 \mathrm{~m}$ above the pool to allow access to the pool for sampling and maintenance. All fuel must be handled remotely. The water depth in the pool cell is 5.8 meters (19 feet). Each assembly is stored vertically in a separate compartment of a rectangular metal rack. 


\section{Fast Flux Test Facility}

Until recent defueling of the FFTF reactor, FFTF assemblies were stored within several different systems at FFTF. Irradiated assemblies were stored within the reactor core, the in-vessel storage (IVS), the interim decay storage (IDS), and the fuel storage facility (FSF). Some irradiated fuel pins were shipped off-site for detailed examination and a few assemblies were temporarily located within the IEM cell, while they were examined. Irradiated assemblies were handled remotely and those within the reactor core, the IVS, the IDS, and the FSF were cooled with liquid sodium. Assemblies were routinely moved between the reactor core, the IVS and the IDS; but once placed in the FSF, fuel assemblies were not reinserted into the reactor. The following paragraphs describe storage at each of the FFTF systems although the reactor has been permanently defueled.

The reactor contains the fueled and non-fueled assemblies, and provides radiation shielding, cooling, and instrumentation to allow safe operation. The reactor is also equipped with instrumentation which permits monitoring of assembly temperature and coolant flow, but is not part of the plant safety system.

The reactor core contains fueled, non-fueled, and control rod assemblies, as well as radial reflectors and shield components, which function together to create a controlled, fast neutron environment. The core consists of nine rows of vertical elements arranged in a hexagonal array. The active zone consists of the 91 positions of the six inner rows. It can be loaded with as many as 82 fueled and non-fueled-test assemblies, with the other nine positions occupied by control rods. The active zone is surrounded by three rows of reflector assemblies.

The IVS is located within the reactor core barrel, but outside of the core region. Fuel stored in the IVS enables the reactor core to be reconfigured during an operating cycle, without opening the reactor vessel. The IVS consists of three storage modules within the reactor, each serving one-third of the reactor core. Each module provides 19 natural-circulation, sodium-cooled receptacles for core components. Each IVS module consists of a top and bottom plate welded together with an elliptical shaped body. The storage receptacles are cylindrical tubes supported by the top and bottom plates. Heat is rejected through the same primary coolant system that services the reactor core.

The IDS is located within the reactor containment building, but outside of the reactor core. It provides a controlled environment for temporary storage of irradiated fuel and other core components between irradiations in the reactor core. The IDS also provides temporary storage of new assemblies and other core components enroute to the core. The IDS is in a rectangular, steel-lined concrete cell. The IDS consists of a rotatable storage basket, contained in a sodium filled, argon inerted, stainless steel primary vessel. A carbon steel guard tank surrounds the primary vessel to help ensure adequate sodium cooling even if the primary vessel were to leak. The atmosphere outside the 
primary vessel, but within the concrete cell, is nitrogen which also serves as a heat transfer medium to control the cell temperature.

There are 122 storage positions for fueled components and other core components, arranged in five concentric circles. The outer four circles can store 112 of the $3.7 \mathrm{~m}$ long core components while the inner circle can store ten special $12 \mathrm{~m}$ long non-fuel assemblies. In order to accommodate these different length assemblies, the IDS has a relatively small cylindrical lower section connected to a larger upper section. The lower cylinder is approximately $6 \mathrm{~m}$ long and $0.25 \mathrm{~m}$ in diameter. The upper section is a cylinder $3.8 \mathrm{~m}$ long and $3.7 \mathrm{~m}$ in diameter. The transition between these sections is a conical section approximately $2 \mathrm{~m}$ long. The primary vessel contains about $60,000 \mathrm{~kg}$ of sodium.

The decay heat of an assembly placed in the IDS must be no greater than $10 \mathrm{~kW}$, while the total inventory decay heat is limited to $155 \mathrm{~kW}$. Decay heat is dissipated by either the primary sodium system for the reactor or the backup nitrogen cooling system.

The FSF is located at the FFTF, in a separate building from the reactor containment building. It provides a controlled environment for longer term storage of irradiated fueled components and other core components. The FSF consists of a primary storage vessel, several closed loop systems and supporting facilities. The fuel is held in a rotatable storage rack contained in a sodium filled, argon inerted, carbon stee] primary vessel. A surrounding carbon steel guard tank ensures adequate sodium containment and cooling, in the event of a primary vessel leak. The FSF is housed in a building of standard industrial above-grade construction and reinforced concrete below-grade construction.

The primary vessel contains 466 positions for assemblies and Ident 69 containers (containers of irradiated assembly fuel or blanket pins) arranged in concentric circles, although only 380 are currently usable due to criticality considerations. The primary vessel is about $6.9 \mathrm{~m}$ in diameter and $7.3 \mathrm{~m}$ long. It is supported by a flange at the top and contains about $100,000 \mathrm{~kg}$ of sodium. The decay heat of an assembiy placed in the FSF must be no greater than 1.4 kilowatts.

Decay heat is removed from the stored materials by natural circulation of the vessel sodium. The sodium transfers heat to two separate sodiumpotassium heat transfer loops, which reject the heat to the atmosphere through a natural draft heat exchanger in each loop. Each loop has a heat removal capacity of $205 \mathrm{~kW}$.

The FSF is designed to interface with the FFTF fuel-handling equipment to facilitate insertion and removal of fueled and non-fueled core components, as are all the FFTF facilities where fuel is held. The FSF makes use of the Bottom Loading Transfer Cask and the FFTF floor valve for these operations. 


\section{Building}

The 324 Building accommodates the study of chemical processes from laboratory to pilot scale at levels of radiation varying from natural background to megacuries (MCi). It also permits examination and mechanical testing of irradiated specimens. The 324 Building contains the laboratory, support facilities including hot cells, and offices required to pursue technical laboratory operations.

The 324 Building is $62.5 \mathrm{~m}$ by $71.6 \mathrm{~m}$ in $\mathrm{pl}$ an and $13.7 \mathrm{~m}$ in height above ground level. The 324 Building has a partial basement, first second, and partial third floors for a total of approximately $9,450 \mathrm{~m}^{2}$ of floor area. The foundation structure is poured-in-place reinforced concrete. The superstructure is constructed from insulated, fluted-steel, industrial panels supported on a structural steel frame.

Fuel in the 324 Building is stored primarily in two hot cells:

- B Cell - is $6.7 \mathrm{~m}$ wide $\times 7.6 \mathrm{~m}$ long $\times 9.3 \mathrm{~m}$ high. The cell is $\mathrm{m}$ below grade and extends $6.2 \mathrm{~m}$ above ground level. The floor and walls are lined with stainless steel. The cell is serviced by two remotely operated cranes with 2.7 and 5.4 metric tons capacity, respectively. These cranes travel through a $5.2 \mathrm{~m}$ high doorway into the neighboring Airlock Cell.

The cell is surrounded on three sides by operating galleries on the first and second floors and on two sides by a gallery at the basement level. Shielding walls at the three operating faces of the first-floor operating gallery level are $1.2 \mathrm{~m}$ thick, high density concrete. Each of these walls has a large viewing window, two master-slave manipulators, and a number sleeved holes for supplying services to the cell. There are two cubicles on the west wall of $B-C e l l$. The remaining cell-to-gallery shielding walls are $1.4 \mathrm{~m}$ and $1.2 \mathrm{~m}$ thick normal concrete at the first and second floors and basement, respectively.

- D Cell - is $4.0 \mathrm{~m}$ wide $\times 6.4 \mathrm{~m}$ long $\times 5.2 \mathrm{~m}$ high and is 1 ocated directly over $\mathrm{C}-\mathrm{Cell}$. The floor between the cells is $0.6 \mathrm{~m}$ thick with a removable floor plug. The short east and west walls are $1.7 \mathrm{~m}$ thick normal concrete and border on the Cask Handling Area and operating gallery, respectively. The long north wall is $1.1 \mathrm{~m}$ thick normal concrete and borders on the Airlock Cell. The long south wall is $1.2 \mathrm{~m}$ thick, high density concrete and borders the operating gallery.

D-Cell is similar to other RE cells ( $A$ and $C$ cells) and has two shielding windows, two pair of master-slave manipulators, a remote viewing periscope, and closed-circuit television. The floor is lined with stainless steel; the walls are lined with mild steel with a corrosion-resistant coating. Access to the cell is via the Airlock Cell or through a small transfer port communicating with a glove box. This glovebox is used for experiments using microcuries of radioactive materials in encapsulated form and 
connects to the ventilation system. A small $10 \mathrm{~cm}$ pass-through port is available for one-way movement of materials into the cell. All normal operations in 0 -Cell are done remotely; all services and facilities are provided at the front face and connected through shielding plugs or offset piping.

Although there are rail spurs in the 300 Area, no direct rail access to the 324 facility is available. Any movement of materials to or from the facility would need to be done by truck. The facility has an overhead crane with a capacity of 27 metric tons, which could be used to move the fuel inside the building. There are also some restrictions to movement of heavy or large objects within the facility, specifically, the floor loading capacity is 1 imited to $978 \mathrm{~kg} / \mathrm{m}^{2}$. The hot cell air lock height is also somewhat limited.

The fuel is stored dry in racks within the cells. Air provides the necessary cooling and is filtered by high efficiency particulate air filters before discharged through an exhaust stack. The fuel is handled remotely with cranes and master-s1ave manipulators.

\section{Building}

The 325 Building was designed to provide space for radiochemical research. The building, located in the 300 area of the Hanford Site, houses the 325-A Radiochemistry Facility and the Shielded Analytical Laboratory. The 325 Building consists of 1) a central portion (completed in 1953) containing general purpose laboratories modified for low-level radiochemical work by provision of special ventilation and work enclosures; 2) a south (front) wing containing office space, locker rooms, a lunch room and maintenance shops; and 3 ) east and west wings provided with shielded enclosures and remote manipulators for high-level radiochemical work.

The central portion of the building is 59.1 by $59.8 \mathrm{~m}$ on three floors (basement, ground, and second) and contains over 100 laboratories and offices. The south wing is 22.6 by $40.5 \mathrm{~m}$ on two floors and contains offices, a conference room, a machine shop, a lunch room, and rest rooms. The east wing (325A), known as the High-Level Radiochemistry Facility, housing the process research hot cells, truck lock, and manipulator repair, is 14.6 by $39.6 \mathrm{~m}$ with a 12.2 by $12.8 \mathrm{~m}$ service area/truck lock addition. The west wing (325B), known as the Shielded Analytical Laboratory, is 16.2 by $16.5 \mathrm{~m}$ and houses additional process research hot cells. Small fuel pieces are stored in the hot cells in both the High-Level Radiochemistry Facility and the Shielded Analytical Laboratory.

The High-Level Radiochemistry Facility contains three interconnecting Cells (A-, B-, and C-Cell) and supporting facilities for work with megacuries of radionuclides. Two of the cells have inside dimensions of $1.8 \mathrm{~m}$ wide by $4.6 \mathrm{~m}$ high by $2.1 \mathrm{~m}$ deep; the third cell has inside dimensions of $4.6 \mathrm{~m}$ wide by $4.6 \mathrm{~m}$ high by $2.1 \mathrm{~m}$ deep. The three cells are enclosed in a $25 \mathrm{~m}$ by $14.6 \mathrm{~m}$ steel-framed, reinforced-concrete 
structure. These cells are shielded with walls of $1.2 \mathrm{~m}$ thick, highdensity concrete on the front and sides and $0.9 \mathrm{~m}$ thick, high-density concrete on the back. Remote operation of the cell equipment is performed in the "front face" operating gallery; movement of materials takes place in the rear support gallery. The rear support gallery also provides access to the cells. The cells are ventilated by air drawn from the rear face gallery and exhausted through testable HEPA filters. The cells are constructed on the first-floor level and supported by heavy reinforced-concrete piers, columns, and pilasters. The basement level contains exhaust ducting, HEPA filters, and other miscellaneous services to the cells. The front side contains manipulators, service ports, and high-density lead-glass windows having equivalent shielding to that of the walls. Each cell has a $45.7 \mathrm{~cm}$ thick Meehanite iron door shielding the main entrance and other smaller entry ports on the back.

B-Cell currently contains a core extruder and analytical measuring equipment used for the tank waste characterization program. A-Cell and C-Ce $\uparrow 1$ contain contaminated equipment from canceled programs, for which clean-up is not currently funded. Currently $\mathrm{A}-\mathrm{Cell}$ and $\mathrm{C}-\mathrm{Cel}$ l are also being used to characterize tank waste.

The Shielded Analytical Laboratory contains six interconnecting "hot" cells and two separate hot cells. The interconnecting cells are $1.7 \mathrm{~m}$ by $1.7 \mathrm{~m}$ compartments inside shielding walls. These compartments are divided into three groups of two compartments each, separated by hollow $10.2 \mathrm{~cm}$ thick sheet metal dividers. The shielding walls on the east and north sides of the cells are $30.5 \mathrm{~cm}$ of Meehanite iron. Shielding walls on the west and south sides are $66 \mathrm{~cm}$ of magnetite concrete. The east side of each compartment is equipped with two manipulators and with high-density, lead-glass viewing windows having the same shielding effect as the walls. These compartments are used for analytical chemistry operations on small amounts of highly radioactive materials such as samples of single-shell tank waste. Operations within the cells are by manipulator or other remote equipment. The other two hot cells are in a separate room and are two all-metal cells. One cell is $2.0 \mathrm{~m}$ long by $1.4 \mathrm{~m}$ wide by $2.5 \mathrm{~m}$ high, inside dimensions, with $15 \mathrm{~cm}$ thick walls and roof. The other cell is $1.7 \mathrm{~m}$ long by $1.5 \mathrm{~m}$ wide by 1.5 $\mathrm{m}$ high, inside dimensions, with $15 \mathrm{~cm}$ thick walls and roof. This cell sits on a pedestal that is $81 \mathrm{~cm}$ above the floor. Both cells have shielded viewing windows, two master-slave manipulators, an access door, and a pass-through port.

Although there are rail spurs in the 300 Area, no direct rail access to the 325 facility is available. Any movement of materials to or from the facility would need to be done by truck. The $325 \mathrm{~A}$ Wing has an overhead crane with 27 metric tons capacity and the 325B Wing has an overhead crane with 2.7 metric tons capacity, which could be used to move the fuel inside the building. 
The 327 Building is a single-story structure with a partial basement. Maximum dimensions are $65.5 \mathrm{~m}$ long by $42.7 \mathrm{~m}$ wide by $9.8 \mathrm{~m} \mathrm{tall}$ and the building is roughly cruciform in shape. The total work area is approximately $2,330 \mathrm{~m}^{2}$ with $929 \mathrm{~m}^{2}$ of laboratory and work areas; $195 \mathrm{~m}^{2}$ of offices; $223 \mathrm{~m}^{2}$ of storage areas; and $975 \mathrm{~m}^{2}$ of common areas containing ventilation and auxiliary equipment. The building framework is welded steel. The exterior walls are fluted steel insulated panels. The primary operating area is on the main floor and includes 11 hot cells, two small shielded cells, two small water pools, the area around the cells (the canyon), and the bays connected to the canyon in which auxiliary operations are performed.

A 13.5 and a 18 metric ton bridge crane are used to transfer casks containing radioactive structural materials or fuel from the receiving area to the cells or between the cells, and for general lifting and transfer service in the canyon.

Materials unaffected by air are examined and tested in shielded cells with an air atmosphere. Cells A through I are shop-fabricated from high-density cast iron (Meehanite) having a specific gravity of 7.3 . The base, walls, and top cover are fitted together by a groove-dowel, lock-together design. The shielded cells rest on a reinforced concrete floor. If direct access is required, a wall may be removed to permit maintenance or to make changes in process or handling equipment.

Most operations in the cells are performed with manipulators. Spaced symmetrically about the iron cell walls are interchangeable plugs that lock in place by expanding retaining rings. Services and viewing ports are supplied through special plugs.

The two lead-brick shielded cells are used for density determination and for deposition of surface films for electron microprobe studies.

The Special Environmental Radiometallurgy Facility or SERF Cell provides an examination and storage facility with a nitrogen atmosphere for specimens that may be affected by air. The facility consists of an upper operating area and a lower storage area. A detachable shielded enclosure at the north end, with access to the operating cel1, houses a remote metallograph for photomicrography, microhardness testing, and sample viewing at high magnification. Two airlocks provide access for entry or removal of test materials, supplies, equipment, and waste without compromising the integrity of the cell atmosphere. Operating equipment is designed to be located entirely within the cell, and operations are performed with manipulators.

The SERF storage cell is located in the basement and is connected to the operating area by a transfer tube. There is a thickness of $1.75 \mathrm{~m}$ of concrete between the ceiling of the SERF storage cell and the floor of the main SERF cell above. Shielding consists of $0.6 \mathrm{~m}$ of concrete on all sides with $10 \mathrm{~cm}$ of lead shielding on the north and west sides and $27 \mathrm{~cm}$ of steel on the operating (east) face. The south side is 
inaccessible since it is adjacent to a building support wall. A manipulator is provided to permit positioning and retrieval of materials in the storage area. Three storage racks are located in the cell, on the wall opposite and on the two walls adjacent to the operating face of the cell. The racks accommodate $6.4 \mathrm{~cm}$ diameter by $10.2 \mathrm{~cm}$ long sample cans and other smaller containers. The three storage racks contain a total of 460 locations.

The purpose of the wet storage basins is to store incoming material before examination and out-going material before shipment. The larger storage basin is $3 \mathrm{~m}$ wide by $4.6 \mathrm{~m}$ long by $5.2 \mathrm{~m}$ deep, with an $2.6 \mathrm{~m}$ deep underwater shelf, $1.2 \mathrm{~m}$ wide, across the width of the basin. The smaller basin is $1.8 \mathrm{~m}$ wide by $2.4 \mathrm{~m}$ long by $3 \mathrm{~m}$ deep. A canal $0.5 \mathrm{~m}$ wide by $3 \mathrm{~m}$ deep connects the large and small basins, to facilitate movements of material from one storage basin to the other. Two $225 \mathrm{~kg}$ jib cranes, one serving each basin are used to transfer materials in the basins. A transfer tube connects Cell A and the small basin. A mechanical sample carrier in the tube provides for sample transfers between cells and the basins. Water quality in the basins is maintained by molecular filters and mixed bed deionizers.

Several racks are located in the large basin for storage of fuel and structural materials. There is one breeder reactor fuel pin storage rack, capable of holding up to 200 pins in a rigid array. The rack consists of $76 \mathrm{~cm}$ long, $2.5 \mathrm{~cm}$ diameter stainless steel tubes arranged in a $4 \times 50$ rectangular array. The tubes are welded into a box-like structure with a stainless steel frame and side panels. The rack sits on the basin floor with the storage tubes oriented vertically. A lifting ring is permanently attached to the top of the rack. The entire rack is $168 \mathrm{~cm}$ long, $61 \mathrm{~cm}$ wide, and $76 \mathrm{~cm}$ high. A wall rack for containers holding individual pins or structural specimens and a peg rack for holding tubing or duct material are located on the north wall of the large storage basin.

The irradiated fuel is stored in several different locations within the Postirradiation Testing Laboratory of 327 Building. The intact fuel pins are stored in a rack in a water basin and in various facility hot cells. The partial fuel pins and small fuel pieces are stored in small cans on shelves in the thirteen hot cells, and in a small dry storage vault.

\section{Area Plutonium Finishing Plant}

The PFP complex is located within the 200 West Area of the Hanford Site. The principal structure, 234-5Z Building, was completed in 1949 to complete the purification of plutonium from Hanford reactors for production of weapons parts. The PFP received plutonium nitrate solutions from the PUREX plant for reduction to plutonium metal and fabrication of parts. In 1989, the final production of plutonium metal for defense purposes ended abruptly without extensive cleaning of the process areas. 
Various forms of plutonium were purified and produced during the operating life of the PFP. The primary product was plutonium metal in the form of ingots called "buttons", produced in the RMA Line and the RMC Line. Plutonium oxide was also produced in the RMA Line. The PFP had the capability to process both weapons-grade material (containing $\mathrm{Pu}^{239}$ with about $6 \% \mathrm{Pu}^{240}$ ) and fuels-grade material (containing $\mathrm{Pu}^{239}$ with about $12 \% \mathrm{Pu}^{240}$ ). In addition to the processing of plutonium produced in Hanford reactors, the PFP has received and processed materials from other DOE reactors and facilities during its operational life. Some of these materials remain in PFP storage vaults, including a significant amount of plutonium oxide with greater than $12 \% \mathrm{Pu}^{240}$.

When processing was stopped at the PFP, reactive forms of plutonium remained in several of the main processing areas in addition to an extensive inventory of partialiy stabilized plutonium forms stored in the secure vaults. The inventory of materials remaining in process areas is contained in the main body of this document. A brief description of the major PFP structures which are of interest to the PFP stabilization effort follows:

The 234-5Z Building is 152 meters (500 feet) long and 55 meters (180 feet) wide, with four levels: basement, first floor, duct level and second floor. The frame is structural stee] with an outer sheathing of aluminum panels over rock wool insulation and 16-gauge sheet metal. There are also $20-\mathrm{cm}(8-i n)$ thick internal reinforced concrete walls, principally running in the longer east to west direction, which extend only to the second floor. Within the 234-5Z Building, various areas house remaining equipment from two plutonium metal production areas and parts fabrication equipment, various purification processes, secure storage vaults, several laboratories and related support areas, extensive ventilation/filtration systems, support office areas and personnel changing rooms. Some processing equipment, primarily the fabrication line and some small purification processes, was removed earlier in the plant history, but the majority of processing equipment remains. The primary areas which contain significant amounts of contamination internal to equipment (holdup) include the inactive RMC and RMA metal production 1 ines, related ventilation ductwork and filter housings (which are still active), analytical laboratory gloveboxes (both active and inactive) and active Plutonium Process Support Laboratory gloveboxes. Work is ongoing to remove and reconfigure several sections of ductwork directly connected to the RMA and RMC processes, which contain the bulk of the holdup.

In the original design of the PFP complex process facilities, all planned operations and laboratories except waste collection and disposal were provided in the 234-5Z Building. Increases in production, storage and scrap recovery requirements made the following major additions necessary:

1961 Waste Incinerator Facility, 232-Z Building

1964 Plutonium Reclamation Facility, 236-Z Building

1964 Waste Storage and Treatment Facility, 24l-Z Building 
1980 Vault Storage Facility: 2736-Z, 2736-ZA, 2736-ZB and 2721-Z Buildings

The 232- $Z$ Building is a concrete-block structure, $11 \mathrm{~m}$ (37 ft) 1ong by $17 \mathrm{~m}$ (57 ft) wide, located just south of 234-5Z Building. It was completed in 1961 and houses an incinerator formerly used to recover plutonium from combustible wastes. The recovered plutonium was recycled through the processing areas at PFP. The incinerator is undergoing deactivation and decommissioning; equipment has been partially dismantled to eliminate most remaining plutonium holdup.

The 236-Z Building is a four-story reinforced concrete structure, $24 \mathrm{~m}$ (79 ft) by $22 \mathrm{~m}(71 \mathrm{ft})$ by about $15 \mathrm{~m}$ (48 $\mathrm{ft}$ ) high, surmounted at the southwest corner by a two-story penthouse which adds $7 \mathrm{~m}(22.5 \mathrm{ft})$ to the building's height. The process cell located in the center of the structure contains many tall, narrow tanks varying in length from $0.8 \mathrm{~m}$ $(2.5 \mathrm{ft})$ to about $15 \mathrm{~m}(50 \mathrm{ft})$. There is an opening in the south concrete wall of the process cell to the equipment transfer facility (added after initial construction), which allows equipment to be moved directly in and out of the cell from outdoors. The building is linked to the 234-5Z Building by another addition, the 242-Z Building. The facility was started in 1964 to recycle scrap plutonium from RMC processing into a purified plutonium nitrate form suitable for metal production. The primary process was solvent extraction, for which most equipment is in the main process cell. Ancillary processing included dissolution of plutonium solids and filtrate evaporation for dilute solutions. All containers of scrap plutonium which were collected in the late 1980s and temporarily stored in the access gloveboxes have now been removed from the PRF and stabilized via muffle furnaces. Process cell interior surfaces, tankage, access gloveboxes and ancillary gloveboxes still contain a significant amount of plutonium holdup.

The 241- $Z$ Building is a $28-\mathrm{m}(92-\mathrm{ft})$ by $6-\mathrm{m}(20-\mathrm{ft})$ by $6.7-\mathrm{m}(22-\mathrm{ft})$ deep underground reinforced concrete structure with a roof at approximately grade level. There are five separate tank cells, each containing a 5000-gallon tank used to accumulate radioactive wastes for adjustment and transfer to Hanford's underground waste storage tanks. Three of the tanks are active at this time, and the remaining two will await decontamination when the building is deactivated. The $243-z$ Building is an active low-level waste treatment facility, added to the PFP complex in 1994. Liquid wastes, primarily cooling water from various systems with in the complex, are collected and treated as necessary in this facility before discharge to the Hanford final treatment and discharge plant.

The 2736- $Z$ vault storage facility is an active standalone complex of secure SNM storage vauits and related support equipment with separate ventilation and personnel facilities, located within the PFP complex just south of the $234-Z$ Building. The $2736-Z$ Building is a one-story reinforced concrete structure, $20 \mathrm{~m}(65 \mathrm{ft})$ long by $17 \mathrm{~m}$ (56 ft) wide, containing SNM storage vaults. The 2736-ZA Building is also of reinforced concrete, $12 \mathrm{~m}(40 \mathrm{ft})$ by $6.7 \mathrm{~m}(22 \mathrm{ft})$, containing exhaust ventilation and filtration equipment for the vaults. The 2736-ZB 
Building is a concrete structure, 40 meters (132 feet) long by 27 meters (90 feet) wide, used for shipping, receiving, repackaging and non-destructive assay of SNM. The 2721-Z Building is a small structure containing backup electrical power equipment. The storage facility is expected to remain active for the foreseeable future, to safely and secureiy store SNM. Facility equipment such as storage pedestals and racks will require modification to accommodate stabilized and repackaged SNM in the DOE-STD-3013 packages which comply with DOE-STD-3013-94. Structural modifications are not anticipated, but the ventilation system may require a capacity increase to accommodate the packaging configuration if metal storage is continued and material is received from other DOE locations. The facility contains only minimal amounts of internal equipment contamination, which will be managed during the life of the facility.

\section{Area Plutonium Finishing Plant Fuel}

Eighty-four grams of 93.2 percent enriched uranium fuel stored at the 2736-ZB Building at the Plutonium Finishing Plant in the 200 West Area of the Hanford Site. The fuel was irradiated at the Uriversity of washington. The fuel is a uranium-aluminum alloy with aluminum cladding. The fuel is contained in a partial assembly of six plates, which are 65.1 centimeters in length, 7.24 centimeters in width and 0.18 centimeters in thickness. The six fuel plates are stored in one 55 gallon drum. The fuel has had very little exposure; its burnup is effectively zero, with surface dose rates of $0.3 \mathrm{mr} / \mathrm{hr}$ gamma and 0.8 $\mathrm{mr} / \mathrm{hr}$ beta plus gamma.

There are 7.8 kilograms of plutonium fuel from the LAMPRE at Los Alamos National Laboratory stored in three EBR II casks within the yard area at PFP. The casks are located within a protective concrete structure.

\section{West Area Low-Leve] Buria] Ground}

There are 17.2 kilograms of uranium from the TRIGA at Oregon State University stored at the 200 Area Low Level Burial Grounds. The uranium hydride fuel in the TRIGA fuel element is mixed with zirconium hydride (8.5\% uranium and $91.5 \%$ zirconium). Six or seven of the aluminum clad fuel assemblies are contained in each of 13 lead-1ined 55 gallon drums. The average weight of the drums is 1,043 kilograms. Overall dimensions of the TRIGA fuel elements are 3.73 centimeters ( 1.47 inches) in outside diameter and 72.1 centimeters (28.4 inches) in length. The fuel was received at Hanford during 1987 and is covered with soil in Trench 7 in $218-W-4 C$.

The 218-W-4C Burial Ground contains trenches with flat, gravel bottoms, and with asphalt bottoms. The $218-W-4 C$ Burial Ground holds the 13 leadlined 55 gallon drums in trench 7 , covered with at least four feet of soil. 
The current storage container, called the TRIGA ${ }^{\oplus}$ Standard Fuel Element Storage Drum is composed of three layers. The outside skin is made from a $17 C$ DOT Specification Container, 49 CFR 178.115, sometimes called a 55-gallon drum. The intermediate container is a carbon steel, 14-inch diameter, schedule 80 pipe section, with a bottom welded closure and a top bolted closure. Normal weight concrete is poured between these two containers. The third and inner container is a 5-inch diameter, schedule 40 pipe. The void between the two pipes is filled with lead shot with lead castings top and bottom. 
WHC-EP-0853 Rev. 3

This page intentionally left blank. 


\section{DISTRIBUTION}

Number of Copies

ONSITE

14 U.S. Department of Energy. Richland Operations office
R. A. Almquist
N2-36
R. M. Hiegel
S7-41
0 . M. Holgado (5)
$57-41$
E. D. Sellers
S7-41
D. W. Templeton (5)
R3 -79
Publ ic Reading Room
$\mathrm{H} 2-53$

3 Pacific Northwest National Laboratory

J. H. Jarrett

P7 -35

D. K. Kreid

$\mathrm{K} 9-18$

Hanford Technical Library

P8-55

34 Westinghouse Hanford Company

G. B. Chronister T5-02

G. J. Cox (5)

T5-50

J. C. Fulton

R3-11

E. W. Gerber

R3-86

W. J. Geuther

T3-28

M. W. Gibson

T5-55

K. R. Herzog (5)

T5-50

T. E. Huber

T5-50

R. K. Hulvey

N2-33.

S. L. Magnani

R3-56

R. L. McCormack

R3-86

A. N. Praga (10)

R3-86

E. C. Vogt

T5-50

J. C. Womack

R3-86

SNF Project Files

R3-11

Document Processing Center

A3-94

Central Files

A3-88

1 Duke Engineering \& Services Hanford, Inc.
R. W. Rasmussen
H5-30 
THIS PAGE INTENTIONALLY LEFT BLANK 